Keywords: DWPF, SB7, Hg, ammonia, hydrogen

Retention: Permanent

\title{
Sludge Batch 7 Qualification and Flowsheet Chemical Process Cell Simulations
}

\author{
A.I. Fernandez
}

February 2011 
SRNL-STI-2011-00006

Revision 0

\section{DISCLAIMER}

This work was prepared under an agreement with and funded by the U.S. Government. Neither the U.S. Government or its employees, nor any of its contractors, subcontractors or their employees, makes any express or implied:

1. warranty or assumes any legal liability for the accuracy, completeness, or for the use or results of such use of any information, product, or process disclosed; or

2. representation that such use or results of such use would not infringe privately owned rights; or

3. endorsement or recommendation of any specifically identified commercial product, process, or service.

Any views and opinions of authors expressed in this work do not necessarily state or reflect those of the United States Government, or its contractors, or subcontractors.

Printed in the United States of America

Prepared for

U.S. Department of Energy 


\section{REVIEWS AND APPROVALS}

\section{AUTHORS}

A.I. Femandez. Process Technology Programs

Date

TECHNICAL REVIEW:

D.C. Koopman, Process Technology Programs

Datc

APPROVAL:

C.C. Hennan, Manager

Date

Process Technology Programs

S.L. Marra, Manager

Date

Environmental \& Chemical Process Technology Research Programs

J.E. Occhipinti, Manager

Date

Waste Solidification Engineering 
SRNL-STI-2011-00006

Revision 0

\section{EXECUTIVE SUMMARY}

The Defense Waste Processing Facility (DWPF) will transition from Sludge Batch 6 (SB6) processing to Sludge Batch 7 (SB7) in fiscal year 2011. SB7 consists of material from Tanks 4, 7, and 12. Tests were conducted using non-radioactive simulants of the expected SB7 compositions, both blend and qualification types, to determine the impact of varying the acid stoichiometry and oxalate concentration during the Sludge Receipt and Adjustment Tank (SRAT) and Slurry Mix Evaporator (SME) processes.

Four qualification runs and five flowsheet runs were performed to simulate the physical and chemical behavior of the Tank 51 material and the blended Tank 51/40 sludge, respectively. The simulants were called SB7-Q and SB7-A. These were produced in the SRNL Continuous Stirred Tank Reactor (CSTR).

The testing covered the domain from 100 to $150 \%$ of the Koopman minimum acid (KMA) equation or about 102 to $155 \%$ using the current DWPF-Hsu acid equation. The high acid runs produced the highest hydrogen gas generation but both the flowsheet and qualification cases never exceeded about $85 \%$ of the maximum allowable rate in the SRAT and SME cycles. The acid processing window for SB7 is approximately 102 to $155 \%$ according to the Hsu equation. It is recommended that $112 \%$ Hsu be used for SB7 processing.

Nitrite ion concentrations were reduced to 760 and $<100 \mathrm{mg} / \mathrm{kg}$ slurry in the qualification and flowsheet 100\% acid (KMA) SRAT products. These indicate that the Koopman equation accurately models the acid needs of SB7-Q and those of SB7-A to a lesser degree. However, even though the flowsheet value could mean an overestimate of the needed acid for nitrite destruction, an intermediate value of nitrite concentration, measured after $75 \%$ of the SRAT reflux had elapsed, yielded a small value of $472 \mathrm{mg} / \mathrm{kg}$. This indicates that while the acid need of the blend simulant was overestimated by KMA, this is a negligible difference.

SB7 simulant processing presented few significant processing issues, regarding either chemical or physical properties. A very small amount of foaming was detected around the agitator shafts during SB7-2 (qualification, high acid) and SB7-5 (flowsheet, low acid) but controlling this foam behavior was not problematic. Also there were no instances of ammonia scrubber column flooding. Based on the SRAT or SME products, whether qualification or flowsheet, there should not be significant issues with mixing or transferring since the rheology was within DWPF limits.

A high oxalate qualification run was performed since part of the real SB7 waste originates from Tank 7 which, after the enhanced chemical cleaning, contains a significantly high concentration of oxalate. This increase of oxalate concentration did not cause any processing difficulties. However, there were two notable chemical effects: decreased hydrogen gas production and decreased mercury stripping. The latter suggests that oxalate could coordinate with mercury.

The performance of an extended run at the prototypical DWPF conditions ( 1 gallon per minute acid addition and $3000 \mathrm{lb} / \mathrm{hr}$ of steam) did not cause any significant problems or adverse changes in gas generation or rheology. The addition of simulated Actinide Removal Process (ARP) and Modular Caustic Side Solvent Extraction Unit (MCU) streams to the SRAT cycle did not influence the recommended acid stoichiometry recommendation.

The SRAT product samples indicated mercury limits were met except for the run with extended processing time, but the mercury balances were not fully elosed. Up to $86 \%$ of the mercury was 
unaccounted for during runs with high acid stoichiometry. High mercury losses during tests at high acid stoichiometry have been noted during previous testing, including SB6 flowsheet testing. Unlike the Phase III SB6 high acid runs, there was no visible deposition of mercury or mercury amalgams on the agitator shaft or blades.

There was a significant amount of ammonium ion and ammonia generated as the $\mathrm{pH}$ rose above neutral during the SRAT cycles, as was the case for SB6. Secondary peak production of hydrogen, $\mathrm{CO}_{2}$, and $\mathrm{N}_{2} \mathrm{O}$ in the high acid runs with both the flowsheet and qualification simulants seem to coincide around the same time, suggesting that a common reactant may be involved in the production of these gases. The production of ammonia and ammonium is likely related to these precursor gases and there is speculation from the SB6 Phase III study that a possible mechanism for producing ammonia would involve a catalyst of either Ru or a mercury amalgam; there is no evidence here that would either support or discard these possibilities.

A high oxalate feed such as SB7 requires accurate measurement of the anion's concentration. Unfortunately, the oxalate values measured in this work were done via water dilution, which has the disadvantage of not measuring the insoluble portion of the oxalate; the previously developed acid strike method for oxalate dissolution failed to give accurate values for the oxalate standards (and presumably the SRAT and SME products as well). Further method development is needed, since the amount of oxalate in the SB7 feed has the potential to contribute up to about \pm 0.05 to the predicted melter glass redox. After the method is finalized, the samples from this study will be re-measured and the report revised to reflect the updated data.

It is recommended that DWPF process SB7 at the following acid stoichiometry: $110 \% \mathrm{KMA}$ or $112 \% \mathrm{Hsu}$. If the need should arise, increments of $5 \%$ in acid stoichiometry up to about $155 \%$ of the Hsu equation could be used in search for optimal processing.

Further study of the mercury chemistry in the CPC process is needed to evaluate the cause of mercury balance closure issues and to determine methods that could increase mercury stripping efficiency. Characterization of the products from this study is being pursued as part of SRNL's efforts to understand mercury chemistry during DWPF processing. 


\section{TABLE OF CONTENTS}

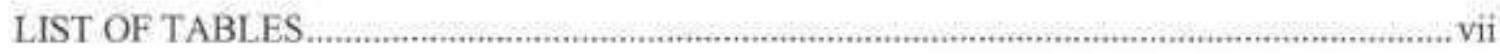

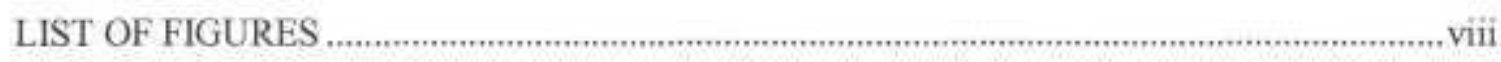

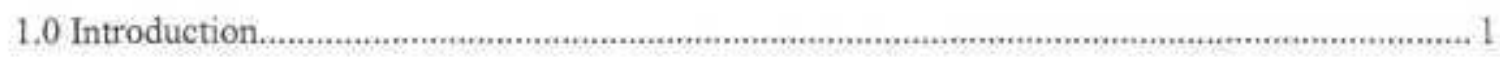

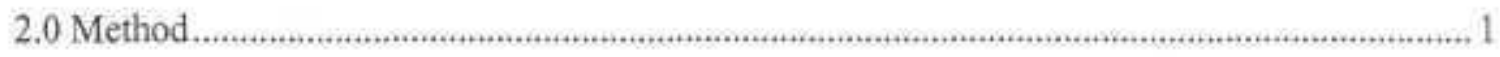

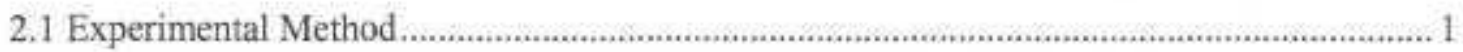

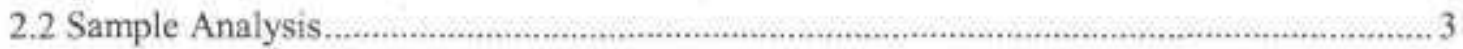

2.3 Simulant Preparation and Composition............................................................................. 4

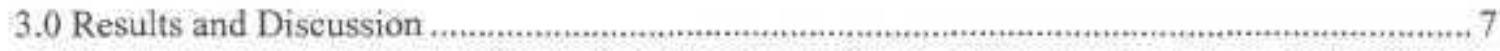

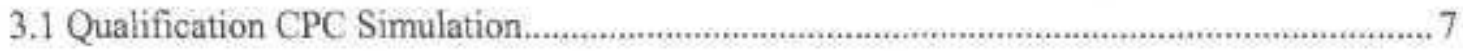

3.1.1 Qualification Elemental/Ion Analyses ........................................................................

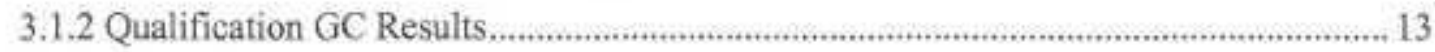

3.1.3 Qualification Ammonia/Ammonium Results ......................................................... 16

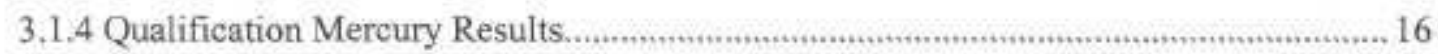

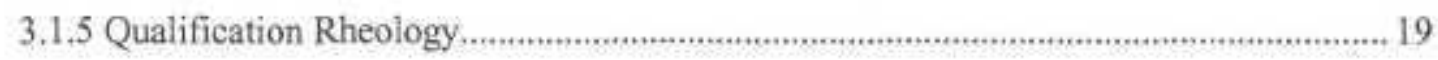

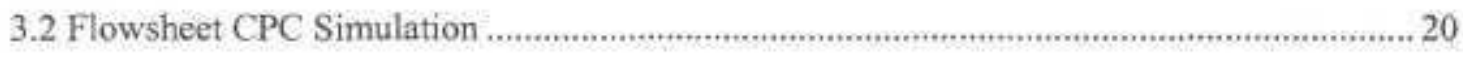

3.2.1 Flowsheet Elemental/Ion Analyses ........................................................................... 20

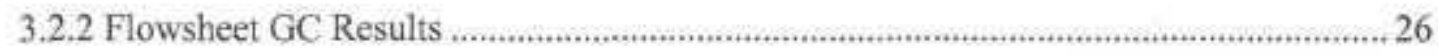

3.2.3 Flowsheet Ammonia/Ammonium Results...............................................................29

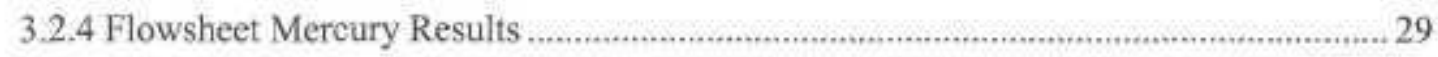

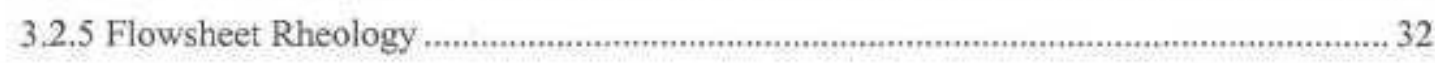

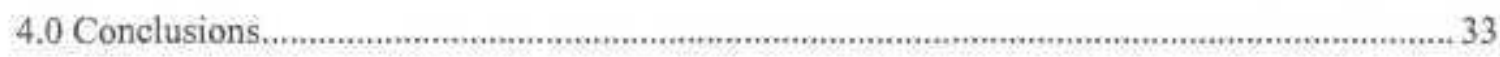

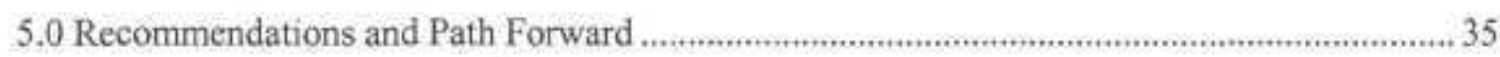

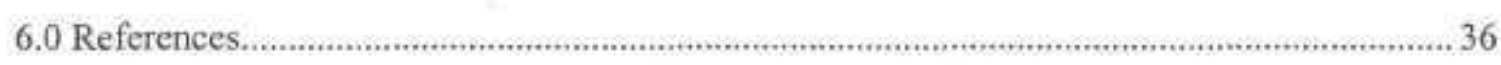

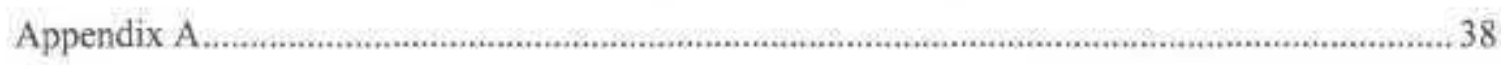




\section{LIST OF TABLES}

Table 1 Comparison of Various Real Washed Sludges to SB6 and SB7 Simulants§......................4

Table 2 Anion composition and density of SB7-Q and SB7-A ..............................................5

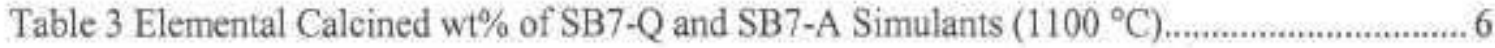

Table 4 Elemental Concentrations of SB7-Q and SB7-A Supernates ......................................... 6

Table 5 Qualification Run Acid Levels .................................................................................... 7

Table 6 Properties of Qualification SRAT Products...................................................................... 8

Table 7 Qualification SRAT Dewater Anions ........................................................................... 8

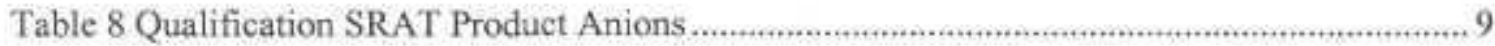

Table 9 Qualification SRAT Anion Reactions ...................................................................... 9

Table 10 Calcined Elemental Composition, wt $\%$, of SRAT Products $\left(1100^{\circ} \mathrm{C}\right) \ldots \ldots \ldots \ldots \ldots \ldots \ldots . . . . . . . . . . .10$

Table 11 Elemental Composition SRAT Product Supernate .........................................................11

Table 12 Properties of Qualification SME Products................................................................. 11

Table 13 Qualification SME Product Anions .....................................................................11

Table 14 Calcined Elemental Composition, wt $\%$, of SME Products $\left(1100^{\circ} \mathrm{C}\right)$............................ 12

Table 15 Elemental Composition of Qualification SME Supernate Products ...............................13

Table 16 Maximum SRAT Gas Generation Rates.................................................................... 13

Table 17 Maximum SME Gas Generation Rates.......................................................................... 14

Table 18 Mercury Composition in Qualification SRAT/SME Slurries ....................................... 16

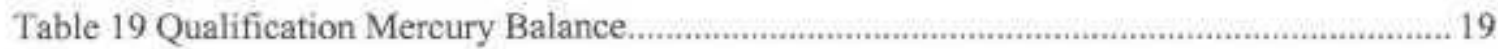

Table 20 Mercury Levels in Qualification Dewater Condensate............................................... 19

Table 21 Qualification SRAT Products Rheology ...................................................................20

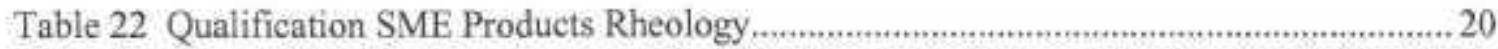

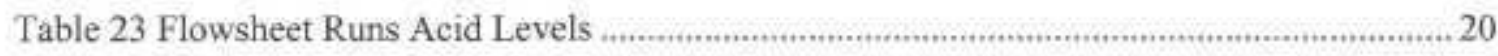

Table 24 Properties of Flowsheet SRAT Products ........................................................................ 21

Table 25 Flowsheet SRAT Dewater Anions.......................................................................................21

Table 26 Flowsheet SRAT Product Anions ..................................................................................22 
Table 27 Flowsheet SRAT Anion Reactions ….......................................................................22

Table 28 Calcined Elemental Composition, wt $\%$, of Flowsheet SRAT Products $\left(1100^{\circ} \mathrm{C}\right) \ldots . . .23$

Table 29 Elemental Composition of Flowsheet SRAT Product Supernate ................................... 24

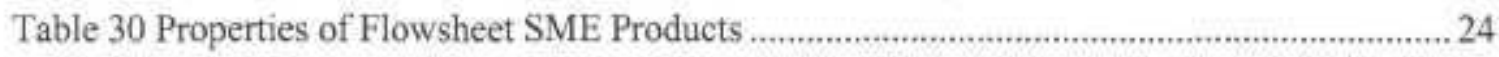

Table 31 Flowsheet SME Product Anions.................................................................................... 25

Table 32 Calcined Elemental Composition, wt $\%$, of Flowsheet SME Products $\left(1100^{\circ} \mathrm{C}\right) \ldots \ldots . . .25$

Table 33 Elemental Composition of Flowsheet SME Product Supernates ..................................26

Table 34 Maximum SRAT Gas Generation Rates.....................................................................2 26

Table 35 Mercury Composition in Flowsheet SRAT/SME Product Slurries .................................. 30

Table 36 Flowsheet Mercury Balance …................................................................................ 32

Table 37 Mercury Levels in Flowsheet Dewater Condensate ....................................................... 32

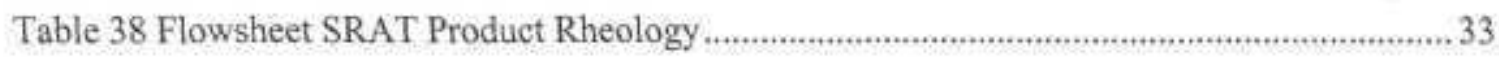

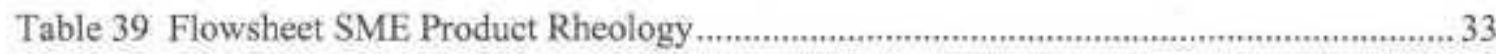

\section{LIST OF FIGURES}

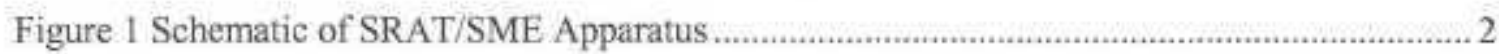

Figure 2 Qualification SRAT/SME Hydrogen Profiles................................................................ 14

Figure 3 Qualification SRAT/SME $\mathrm{CO}_{2}$ Profiles ..................................................................... 15

Figure 4 Qualification SRAT/SME $\mathrm{N}_{2} \mathrm{O}$ Profiles................................................................. 15

Figure 5 Qualification SRAT Ammonia and Ammonium Concentrations................................... 16

Figure 6 Qualification Slurry Mercury Measurements .............................................................17

Figure 7 Qualification Gaseous Mercury Measurements .............................................................. 18

Figure 8 Flowsheet SRAT/SME Hydrogen Profiles.................................................................27

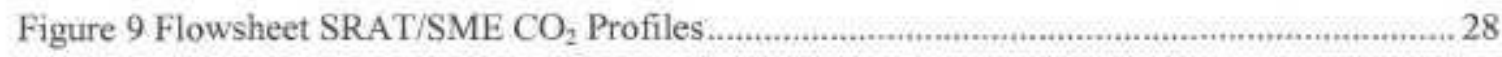

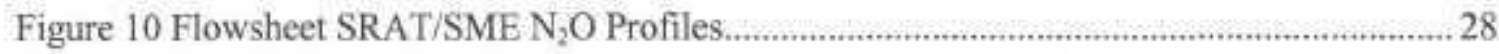

Figure 11 Flowsheet SRAT Ammonia and Ammonium Concentrations ....................................29 
Figure 12 Flowsheet Slurry Mercury Measurements......................................................................... 30

Figure 13 Flowsheet Gaseous Mercury Measurements ..............................................................31

Figure 14 Qualification pH Time Profiles .....................................................................................39

Figure 15 Flowsheet pH Time Profiles .............................................................................. 39

Figure 16 Qualification SME Hydrogen Generation .............................................................,40

Figure 17 Qualification SME $\mathrm{CO}_{2}$ Generation …........................................................................40

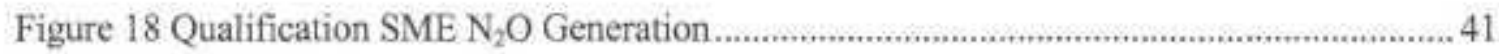

Figure 19 Flowsheet SME Hydrogen Generation.......................................................................41

Figure 20 Flowsheet $\mathrm{SME} \mathrm{CO}_{2}$ Generation........................................................................ 42

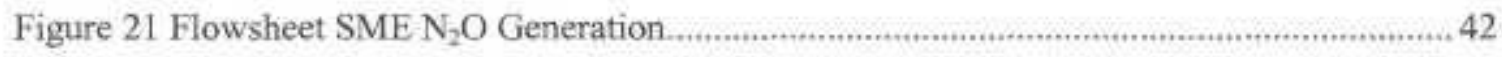

Figure 22 SB7-1 SRAT Rheology Flow Curve …................................................................ 43

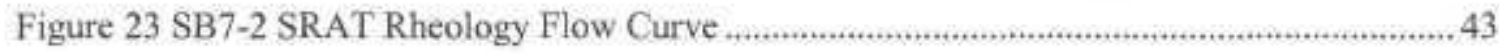

Figure 24 SB7-3 SRAT Rheology Flow Curve …..................................................................4

Figure 25 SB7-4 SRAT Rheology Flow Curve …................................................................

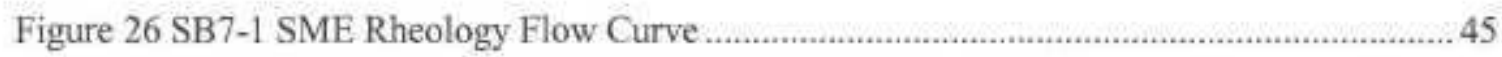

Figure 27 SB7-2 SME Rheology Flow Curve ….................................................................... 45

Figure 28 SB7-3 SME Rheology Flow Curve …................................................................. 46

Figure 29 SB7-4 SME Rheology Flow Curve ….................................................................. 46

Figure 30 SB7-5 SRAT Rheology Flow Curve …........................................................... 47

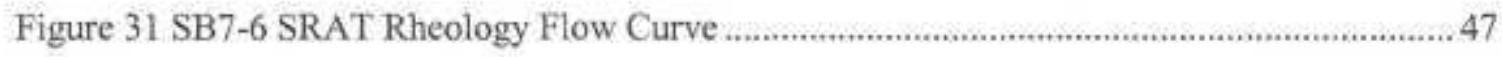

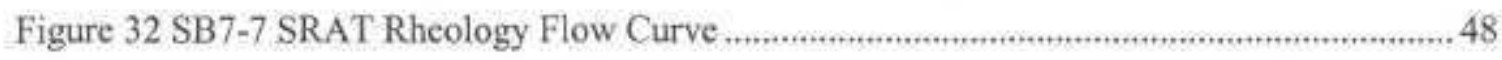

Figure 33 SB7-8 SRAT Rheology Flow Curve ….................................................................... 48

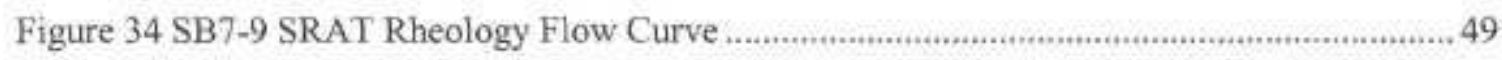

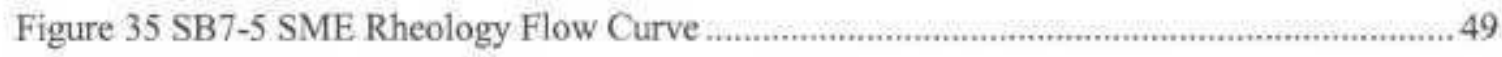

Figure 36 SB7-6 SME Rheology Flow Curve …............................................................ 50

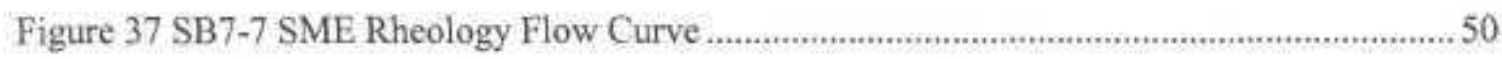

Figure 38 SB7-8 SME Rheology Flow Curve ……...............................................................51

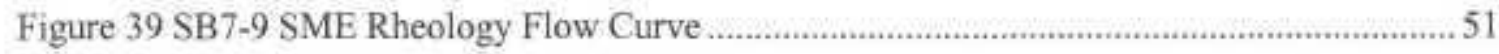




\section{LIST OF ABBREVIATIONS}

\begin{tabular}{ll} 
ACTL & Aiken County Technology Laboratory \\
AD & Analytical Development \\
CPC & Chemical Process Cell \\
CS & Calcined Solids \\
CSTR & Continuous-Stirred Tank Reactor \\
DWPF & Defense Waste Processing Facility \\
FAVC & Formic Acid Vent Condenser \\
GC & Gas Chromatography \\
IC & Ion Chromatography \\
ICP-AES & Ion Chromatography-Atomic Energy Spectroscopy \\
IS & Insoluble Solids \\
MWWT & Mercury Water Wash Tank \\
PSAL & Process Science Analytical Laboratory \\
REDOX & Reduction/Oxidation Potential \\
SBx & Sludge Batch number x \\
SME & Slurry Mix Evaporator \\
SRAT & Sludge Receipt and Adjustment Tank \\
SRNL & Savannah River National Laboratory \\
SS & Soluble Solids \\
TS & Total Solids \\
TT\&QAP & Technical Task and Quality Assurance Plan \\
TTR & Technical Task Request \\
\hline
\end{tabular}




\subsection{Introduction}

The Defense Waste Processing Facility (DWPF) will transition from Sludge Batch 6 (SB6) processing to Sludge Batch 7 (SB7) in fiscal year 2011. Tank 4, 7, and 12 material comprises the SB7 sludge. Tests were conducted using non-radioactive simulants of the expected SB7 compositions, both blend and qualification types, to determine the impact of varying the acid stoichiometry during the Sludge Receipt and Adjustment Tank (SRAT) and Slurry Mix Evaporator (SME) processes. The work was performed to meet the Technical Task Request (TTR) HLW-DWPF-TTR-2010-0012, ${ }^{1}$ and the subsequent guidelines of a Task Technical and Quality Assurance Plan (TT\&QAP) SRNL-RP-2010-0071. ${ }^{2}$

The primary justification for this work is to evaluate the acid window while measuring the impact of the acid addition on hydrogen gas generation as well as $\mathrm{N}_{2} \mathrm{O}$ and $\mathrm{CO}_{2}$ production. A notable difference of this batch is the high concentration of oxalate; the reason for this increase is that Tank 7, which is a major component of the feed to Tank 51/SB7 sludge, holds the material removed during oxalic acid chemical cleaning of Tanks 5 and $6^{3.6}$. Additional reasons for examining the behavior of SB7 are to understand the effects of combining a relatively high mercury level, ca. $2 \mathrm{wt} \%$, and some of the largest noble metal (namely $\mathrm{Rh}$ and Ru) concentrations to date. Measurements included pH, off-gas, and mercury stripping profiles. For most of the runs, reflux and dewatering lasted about 24 hours at the scaled DWPF design maximum boil-up rate of $5,000 \mathrm{lb} / \mathrm{hr}$ of steam; similarly acid addition was added at the scaled design rate of 2 gallon per minute. The flowsheet study included an "extended" run which operated at prototypical DWPF conditions, 1 gallon per minute of acid addition and a boil-up rate of $3,000 \mathrm{lb} / \mathrm{hr}$ of steam.

\subsection{Method}

\subsection{Experimental Method}

These SRAT/SME experiments were performed in the SRNL facilities within the Aiken County. Technology Laboratory (ACTL). As stated above, this study consisted of two types of runs, SB71 though SB7-4 for the qualification study and SB7-5 through SB7-9 for the flowsheet study; the experiments were conducted using two 4-L rigs.

Figure 1 shows a schematic of the SRAT apparatus. Details of the SRAT equipment are given in the equipment set-up memo ${ }^{7}$ and details of the experimental procedures are given by Procedure ITS-00094, Rev, 3 from the L29 manual. However, information regarding a somewhat recent addition to the apparatus is discussed here. An ammonia gas absorption column (or ammonia scrubber) was added to the SRAT apparatus to collect ammonia in the off-gas for quantification of the generation rate and amount, and to protect the Nafion dryer. The ammonia scrubber used a solution of $749 \mathrm{~g}$ of de-ionized water and $1 \mathrm{~g}$ of $50 \mathrm{wt} \%$ nitric acid. This solution allowed for absorption of ammonia gas, yielding the aqueous ammonium cation, $\mathrm{NH}_{4}^{+}$. The solution was circulated by a Micropump gear pump at about $300 \mathrm{~mL}$ per minute to a spray nozzle at the top of the packed section. The addition of the scrubber to the off-gas system slightly increased the back-pressure on the SRAT vessel and led to a small increase in fugitive emissions at the various fittings; thus, water vapor loss increased as well. 


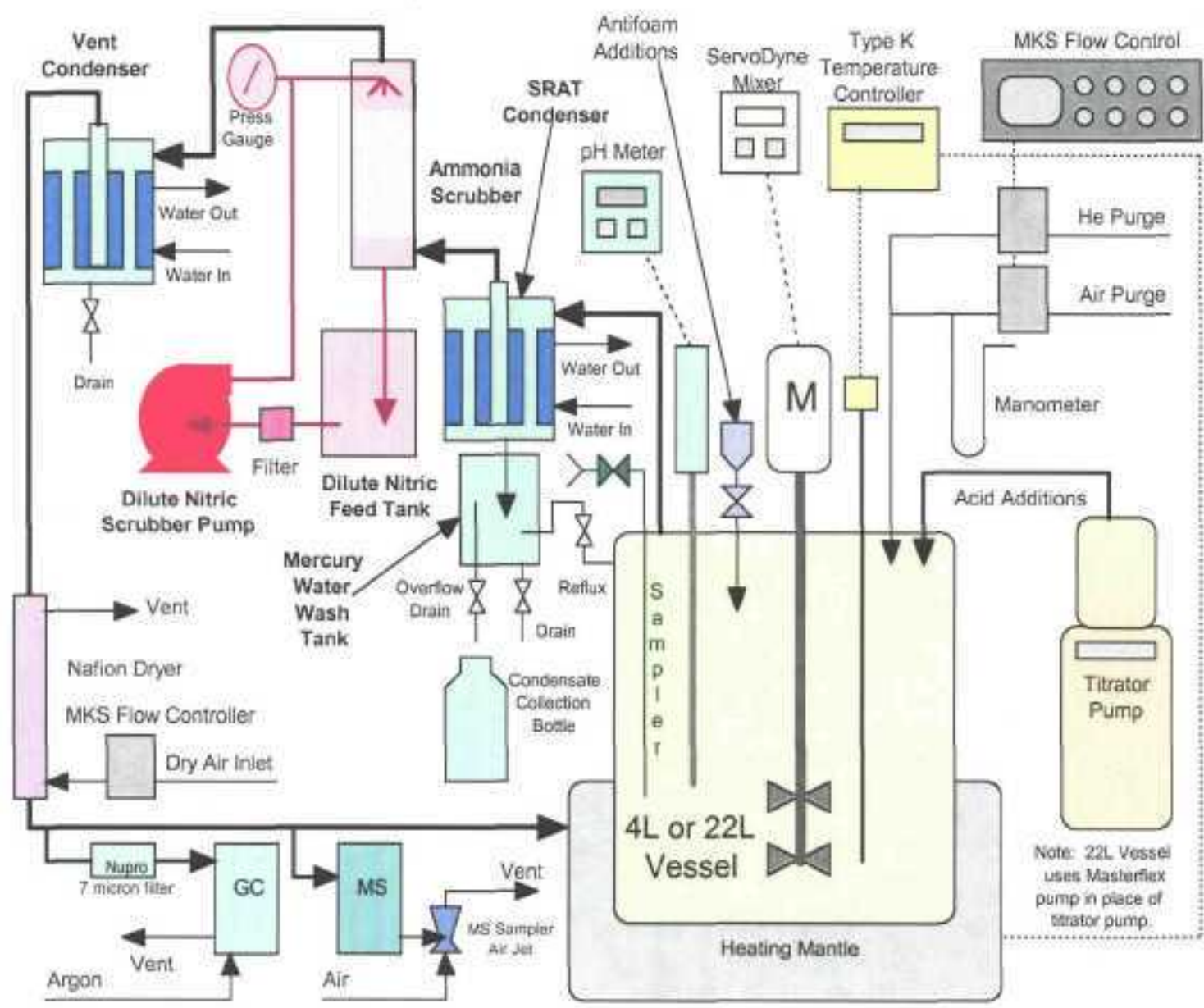

Figure 1 Schematic of SRAT/SME Apparatus

The automated data acquisition system developed for the 4-L SRAT rigs was used to collect electronic data on a computer. Process variable data included SRAT slurry temperature, bath temperatures for the cooling water to the SRAT condenser and Formic Acid Vent Condenser (FAVC), slurry pH, SRAT mixer speed and torque, and air and helium purge flows (helium is used as an internal standard set to $0.5 \%$ of the nominal SRAT purge air flow). Cumulative acid addition volume data were collected from the automated dispensers using an algorithm that matches the indicated total on the dispenser. Some $\mathrm{pH}$ data were obtained for the nitric acid reservoir that supplied the reflux flow to the ammonia scrubbers.

Raw GC chromatographic data were acquired on separate computers dedicated to each instrument. The chilled off-gas leaving the FAVC was passed through a Nafion dryer in counter-current flow with a dried air stream to reduce the moisture content at the GC inlet. Agilent $3000 \mathrm{~A}$ micro GCs were used on both runs. The GCs were baked out before the runs. Column-A can collect data related to $\mathrm{He}, \mathrm{H}_{2}, \mathrm{O}_{2}, \mathrm{~N}_{2}, \mathrm{NO}$, and $\mathrm{CO}$, while column-B can collect data related to $\mathrm{CO}_{2}, \mathrm{~N}_{2} \mathrm{O}$, and water. GC's were calibrated with a standard calibration gas containing 0.500 vol\% $\mathrm{He}, 1.000$ vol $\% \mathrm{H}_{2}, 20.00$ vol $\% \mathrm{O}_{2}, 51.50$ vol $\% \mathrm{~N}_{2}, 24.50$ vol $\% \mathrm{CO}_{2}$ and $2.50 \mathrm{vol} \% \mathrm{~N}_{2} \mathrm{O}$. The calibration 
was verified prior to starting the SRAT cycle and after completing the SRAT cycle. Room air was used to give a two point calibration for $\mathrm{N}_{2}$.

\subsection{Sample Analysis}

Chemical and physical measurements of samples of off-gas and condensed media, both supernate and slurry have been performed. The chemical measurements consisted of analyzing samples for $\mathrm{pH}$ and composition values while the physical measurements consisted of rheology and density measurements.

Process samples were analyzed by various methods. Slurry and supernate elemental compositions were determined by inductively coupled plasma-atomic emission spectroscopy (ICP-AES) at the Process Science Analytical Laboratory (PSAL). Slurry samples were calcined at $1100^{\circ} \mathrm{C}$. The main advantage of this approach is to permit easier comparisons between SRAT product elements and sludge elements. Noble metals and mercury are trimmed uniquely to each SRAT, and their concentrations are known more accurately from material balance considerations than they could be from ICP-AES analyses. Dewatering condensate samples were sent to PSAL. to check for dissolved mercury via ICP-AES.

Water soluble anions were determined by ion chromatography (IC) on 100-fold weighted dilutions of slurry followed by filtration to remove the remaining insoluble solids. The starting sludge was titrated to $\mathrm{pH} 7$ using the PSAL auto-titrator to determine the base equivalents for input into the stoichiometric acid equation. Ammonium ion concentrations were measured from samples of SRAT cycle slurries, SRAT product slurries, SRAT cycle condensates, and ammonia scrubber liquids (see above for scrubber description) by AD using IC.

Ammonia and mercury gas concentrations at the SRAT condenser exit were measured via a Sensidyne colorimetric gas detector tube system. Gas measurements were performed in the second half of the SRAT reflux period since $\mathrm{NO}_{\mathrm{x}}$, present to a larger degree during acid addition, dewatering, and earlier in the SRAT reflux period, interferes with the colorimetric tube performance.

Slurry and supernate densities were measured by PSAL using the Anton-Parr instrument. A Mettler solids analyzer was used to obtain the total solids, soluble solids, and insoluble solids weight percents.

Slurry rheology measurements were obtained by using a Haake RS- 600 rheometer with the Z41 concentric cylinder geometry (SRAT product) and Z38 cylinder (SME product). uses a Searle type measuring system, where both speed and torque are measured at the rotating shaft. This was operated in the controlled rate mode for all of the data reported here. Flow curves were obtained by varying the shear rate from 0 to 600 seconds $^{-1}$ (SRAT products) or 0 to 300 seconds $^{-1}$ (SME products) over a given time period; measurements of the shear stress were obtained from the torgue on the rotating shaft. 


\section{3 $\underline{\text { Simulant Preparation and Composition }}$}

Both simulants, SB7-Q for the qualification studies and SB7-A for the flowsheet work, were prepared using the current continuous stirred reactor (CSTR) precipitation method. ${ }^{9}$ The method involved the following steps
a. precipitated $\mathrm{MnO}_{2}$ was added
b. metal nitrate solution was prepared
c. these two were combined along with a $50 \%$ sodium hydroxide solution to produce a caustic slurry of hydrous metal oxide and insoluble hydroxides in a sodium nitrate solution at $\mathrm{pH} \sim 9.5$
d. sodium carbonate was added to convert some hydroxides to carbonates
e. the slurry was washed and decanted until the nitrate concentration was below the target supernate nitrate concentration
f. concentration allowed for attainment of the target total solids value
g. silica and titanium oxide were added to complete the raw sludge
h. soluble sodium salts were added to bring the supernate composition to target values

Table 1 lists some overall features of various sludges (including the trim chemicals). There are six Shielded Cell (SC) sets of data, the last four of which are labeled as such and followed by a run number. The SC-11 column refers to the rad work performed on the SB7 qualification sample from Tank 51. ${ }^{10}$ The SB6-G column refers to the simulant blend while the last two refer to the present work, simulants used for the qualification and blend CPC simulations of SB7. The weight percent of $\mathrm{Mn}$ is on a calcined solids basis while those of mercury and the noble metals refer to a total solids basis. SB7 has a moderately high mercury level, about $2 \%$ total solids, close to that of SB5 but less than SB6, which was about 3\%. The noble metals concentrations are elevated, even greater than those of SB6.

Table 1 Comparison of Various Real Washed Sludges to SB6 and SB7 Simulants§

\begin{tabular}{|c|c|c|c|c|c|c|c|c|c|}
\hline & $\begin{array}{l}\mathrm{SB2}^{11} \\
(\mathrm{SC})\end{array}$ & $\begin{array}{l}\mathrm{SB}^{1 / 2} \\
(\mathrm{SC})\end{array}$ & $\begin{array}{l}\mathrm{SB}^{\mathrm{IB}} \\
(\mathrm{SC}-3)\end{array}$ & $\begin{array}{l}\text { SB5 }^{14} \\
(\mathrm{SC}-6)\end{array}$ & $\begin{array}{l}\text { SB6 }{ }^{15} \\
\text { (SC-9) }\end{array}$ & $\begin{array}{l}\text { SB6-G }^{15} \\
\text { Blend }\end{array}$ & $\begin{array}{c}\mathrm{SB}^{10} \\
(\mathrm{SC}-11)\end{array}$ & $\begin{array}{l}\text { SB7-Q } \\
\text { Qual }\end{array}$ & $\begin{array}{l}\text { SB7-A } \\
\text { Blend }\end{array}$ \\
\hline Wt $\% \mathrm{TS}$ & 18,4 & 27.2 & 19.5 & 17.1 & 15.1 & 17.8 & 18.1 & 18.1 & 18.5 \\
\hline Wt $\%$ IS & 15.0 & 17.1 & 16.5 & 11.2 & 9.9 & 10.9 & 12.3 & 12.6 & 13.1 \\
\hline Wt $\%$ SS & 3.4 & 10.1 & 3.0 & 5.9 & 5.2 & 6.9 & 5.8 & 5.5 & 5.4 \\
\hline Wt $\%$ CS & 15.7 & $\mathrm{~N} / \mathrm{A}$ & 16.6 & 14.0 & 11.9 & 13.9 & 13.3 & 13.6 & 13.6 \\
\hline Base, M & 0.308 & 0.577 & 0.316 & 0.739 & 0.58 & 0.839 & 0.38 & 0.538 & 0.507 \\
\hline TIC $^{\dagger}$ & 866 & 1,260 & 2,510 & 1,280 & 913 & 1,050 & 912 & 1,380 & 1,180 \\
\hline Nitrite & 7,529 & 25,300 & 20,500 & 8,660 & 10,000 & 13,950 & 9,900 & 9,140 & 9,605 \\
\hline $\mathrm{Mn}, \mathrm{wt} \%$ & 3.21 & 3.98 & 1.94 & 3.66 & 4.15 & 4.82 & 4.26 & 4.37 & 5.12 \\
\hline $\mathrm{Hg}, \mathrm{wt} \%$ & 0.195 & 0.0654 & 2.57 & 2.2 & 3.12 & 2.79 & 1.5 & 1.94 & 2.16 \\
\hline $\mathrm{Pd}, \mathrm{wt} \%$ & 0.0009 & 0.0017 & 0.0010 & 0.0040 & 0.0030 & 0.0028 & 0.0026 & 0.0021 & 0.0020 \\
\hline $\mathrm{Rh}, \mathrm{wt} \%$ & 0.0078 & 0.0071 & 0.0124 & 0.0250 & 0.0187 & 0.0177 & 0.0188 & 0.0268 & 0.0267 \\
\hline $\mathrm{Ru}, \mathrm{wt} \%$ & 0.0332 & 0.0362 & 0.0529 & 0.110 & 0.0924 & 0.0846 & 0.0902 & 0.0227 & 0.0222 \\
\hline Acid $^{2}$ & 0.751 & 1.63 & 1.30 & 1.32 & 1.12 & 1.49 & 1.05 & 1.30 & 1.33 \\
\hline
\end{tabular}

$\S \mathrm{TS}, \mathrm{IS}, \mathrm{SS}$, and CS mean total solids, insoluble solids, soluble solids, and calcined solids.

$+\mathrm{mg} / \mathrm{kg}$

$\$ \mathrm{~mol} / \mathrm{L}$ 
Table 2 shows the slurry and supernate density and anion levels of the sludges. Note that the nitrite level is significantly lower in SB7, compared to SB6. As a side note, there is less chlorine in SB7 which could preclude some reactions with mercury to produce mercuric chloride $\left(\mathrm{HgCl}_{2}\right)$ and mercurous chloride (calomel, $\mathrm{Hg}_{2} \mathrm{Cl}_{2}$ ); however, a small amount of chlorine is introduced upon trimming with $\mathrm{RuCl}_{3}$ in the simulant testing. Since the ratio of mercury to chlorine atoms is 8.0 and 9.3 for the qualification and flowsheet runs, respectively, it is not likely that chlorine has a dominant impact on mercury chemistry; however a possibility could include catalysis.

Table 2 Anion composition and density of SB7-Q and SB7-A

\begin{tabular}{|l|c|c|c|c|}
\hline & $\begin{array}{c}\text { SB6-G } \\
\text { Blend }\end{array}$ & $\begin{array}{c}\text { SB7 } \\
\text { (SC-11) }\end{array}$ & $\begin{array}{c}\text { SB7-Q } \\
\text { Qual }\end{array}$ & $\begin{array}{c}\text { SB7-A } \\
\text { Blend }\end{array}$ \\
\hline Nitrite, $\mathrm{mg} / \mathrm{kg}$ & 13,950 & 9,900 & 9,140 & 9,605 \\
\hline Nitrate, $\mathrm{mg} / \mathrm{kg}$ & 8,030 & 7,900 & 6,465 & 5,880 \\
\hline Sulfate, $\mathrm{mg} / \mathrm{kg}$ & 1,820 & 2,100 & 1,460 & 1,345 \\
\hline Chloride, $\mathrm{mg} / \mathrm{kg}$ & 244 & $<400$ & $<100$ & $<100$ \\
\hline Slurry TIC, $\mathrm{mg} / \mathrm{kg}$ slurry & 1,047 & 912 & 1,380 & 1,180 \\
\hline Supernate TIC, $\mathrm{mg} / \mathrm{kg}$ supernate & 916 & 867 & 664 & 757 \\
\hline Slurry density, g/mL & 1.149 & 1.15 & 1.142 & 1.144 \\
\hline Supernate density, $\mathrm{g} / \mathrm{mL}$ & 1.062 & 1.05 & 1.053 & 1.051 \\
\hline
\end{tabular}

Since the water dilution method that is used in the PSAL analysis may not dissolve less soluble species such as calcium oxalate, oxalate concentrations are not listed in Table 2 . The lack of an accurate determination of the oxalate concentration limits the ability to gauge the effect of increasing the oxalate, even if the amount added during SB7-4, $8495 \mathrm{mg} / \mathrm{kg}$, is $\mathrm{known}$.

Table 3 lists the calcined elemental composition of both sludges and allows for comparison with the previous sludge SB6-G; the units are $w t \%$ on a calcined basis. Note that the differences in composition are not great. Table 4 lists the elemental supernate concentrations in $\mathrm{mg} / \mathrm{L}$. 
Table 3 Elemental Calcined wt $\%$ of SB7-Q and SB7-A Simulants $\left(1100^{\circ} \mathrm{C}\right)$

\begin{tabular}{|c|c|c|c|c|}
\hline Element & $\begin{array}{c}\text { SB6-G } \\
\text { Blend }\end{array}$ & $\begin{array}{c}\text { SB7 } \\
(\text { SC-11 })\end{array}$ & $\begin{array}{c}\text { SB7-Q } \\
\text { Qual }\end{array}$ & $\begin{array}{c}\text { SB7-A } \\
\text { Blend }\end{array}$ \\
\hline $\mathrm{Al}$ & 13.0 & 14.4 & 15.7 & 15.9 \\
\hline $\mathrm{Ba}$ & 0.131 & 0.12 & 0.102 & 0.113 \\
\hline $\mathrm{Ca}$ & 0.634 & 0.76 & 0.836 & 0.831 \\
\hline $\mathrm{Ce}$ & 0.197 & 0.16 & 0.148 & 0.158 \\
\hline $\mathrm{Cr}$ & 0.167 & 0.058 & 0.046 & 0.064 \\
\hline $\mathrm{Cu}$ & 0.095 & 0.053 & 0.033 & 0.052 \\
\hline $\mathrm{Fe}$ & 20.6 & 18.0 & 19.2 & 19.9 \\
\hline $\mathrm{K}$ & 0.085 & 0.088 & 0.125 & 0.120 \\
\hline $\mathrm{La}$ & 0.103 & --078 \\
\hline $\mathrm{Mg}$ & 0.505 & 0.38 & 0.070 & 0.413 \\
\hline $\mathrm{Mn}$ & 6.18 & 4.26 & 0.366 & 5.12 \\
\hline $\mathrm{Na}$ & 17.6 & 19.0 & 4.37 & 14.7 \\
\hline $\mathrm{Ni}$ & 2.77 & 3.1 & 15.3 & 3.31 \\
\hline $\mathrm{P}$ & $<0.1$ & 0.087 & $<.37$ & $<0.1$ \\
\hline $\mathrm{Pb}$ & $<0.01$ & 0.04 & 0.025 & 0.022 \\
\hline $\mathrm{S}$ & 0.390 & 0.52 & 0.371 & 0.336 \\
\hline $\mathrm{Si}$ & 1.26 & 2.01 & 1.91 & 1.87 \\
\hline $\mathrm{Ti}$ & 0.028 & 0.02 & 0.025 & 0.026 \\
\hline $\mathrm{Zn}$ & 0.090 & -- & 0.047 & 0.060 \\
\hline $\mathrm{Zr}$ & 0.264 & 0.16 & 0.252 & 0.254 \\
\hline
\end{tabular}

Table 4 Elemental Concentrations of SB7-Q and SB7-A Supernates

\begin{tabular}{|c|c|c|c|}
\hline Element & $\begin{array}{c}\text { SB6-G } \\
\text { Blend }\end{array}$ & $\begin{array}{c}\text { SB7-Q } \\
\text { Qual }\end{array}$ & $\begin{array}{c}\text { SB7-A } \\
\text { Blend }\end{array}$ \\
\hline $\mathrm{Al}$ & 3,600 & 2,460 & 2,130 \\
\hline $\mathrm{Ba}$ & $<0.1$ & $<0.1$ & $<0.1$ \\
\hline $\mathrm{Ca}$ & 5.85 & 2.38 & 2.33 \\
\hline $\mathrm{Ce}$ & $<10$ & $<0.1$ & $<0.1$ \\
\hline $\mathrm{Cr}$ & 52.4 & 6.34 & 17.4 \\
\hline $\mathrm{Cu}$ & $<1$ & 0.414 & 0.343 \\
\hline $\mathrm{Fe}$ & $<0.1$ & $<0.1$ & $<0.1$ \\
\hline $\mathrm{K}$ & 280 & 160 & 129 \\
\hline $\mathrm{La}$ & $<0.1$ & $<0.1$ & $<0.1$ \\
\hline $\mathrm{Mg}$ & $<0.1$ & $<0.1$ & $<0.1$ \\
\hline $\mathrm{Mn}$ & $<0.1$ & $<0.1$ & $<0.1$ \\
\hline $\mathrm{Na}$ & - & 23,850 & 20,600 \\
\hline $\mathrm{Ni}$ & $<0.1$ & $<0.1$ & $<0.1$ \\
\hline $\mathrm{P}$ & $<10$ & $<10$ & $<10$ \\
\hline $\mathrm{Pb}$ & $<0.1$ & $<0.1$ & $<0.1$ \\
\hline $\mathrm{S}$ & 975 & 763 & 706 \\
\hline $\mathrm{Si}$ & 2.20 & 0.685 & 0.423 \\
\hline $\mathrm{Sn}$ & - & 1.32 & 2.36 \\
\hline $\mathrm{Ti}$ & $<0.1$ & $<0.1$ & $<0.1$ \\
\hline $\mathrm{Zn}$ & $<0.1$ & $<0.1$ & $<0.1$ \\
\hline $\mathrm{Zr}$ & $<0.1$ & $<0.1$ & $<0.1$ \\
\hline & & & \\
\hline
\end{tabular}




\subsection{Results and Discussion}

Two sets of SRAT/SME simulations were performed, qualification and flowsheet. The flowsheet work models the behavior of SB7 processing after the initial mixing with the SB6 heel while the qualification studies reflect the behavior of the SB7 sludge as prepared in Tank 51 and targets the composition of the sludge used during Shielded Cells qualification testing.

\subsection{Qualification CPC Simulation}

Four runs were performed for the qualification portion of this work, as identified by run numbers SB7-1 through SB7-4. Table 5 shows the acid stoichiometric factors and acid added. The acid equations are discussed in detail elsewhere. ${ }^{16}$ The SB7-4 high oxalate run consisted of increasing the oxalate concentration by $8,495 \mathrm{mg} / \mathrm{kg}$; this value is accurate and was obtained by adding a known mass of sodium oxalate to the SRAT vessel just prior to the beginning of the SRAT cycle. However, as noted above, the oxalate concentration measurements of the raw sludge are uncertain.

Table 5 Qualification Run Acid Levels

\begin{tabular}{|l|c|c|c|}
\hline \multicolumn{1}{|c|}{ Run ID - Function } & $\begin{array}{c}\text { Acid, } \\
\mathbf{m o l} / \mathbf{L}\end{array}$ & Hsu factor & KMA factor $\boldsymbol{\dagger}$ \\
\hline SB7-1 - Low acid & 1.18 & $103 \%$ & $100 \%$ \\
\hline SB7-2 - High acid & 1.78 & $146 \%$ & $150 \%$ \\
\hline SB7-3 - Baseline & 1.30 & $107 \%$ & $110 \%$ \\
\hline SB7-4 - High Oxalate & 1.30 & $107 \%$ & $110 \%$ \\
\hline SC-11* & 1.05 & $118 \%$ & $110 \%$ \\
\hline
\end{tabular}

$\dagger$ Koopman minimum acid

* SC-11 pertains to SB7/Tank 51 qualification sample demonstration

SB3 studies showed acid consumption increased with increasing oxalate concentration; sodium oxalate was the compound used to introduce the oxalate into the sludge. Current stoichiometric acid equations, however, do not adjust the calculated acid demand for oxalate. Therefore, it is expected that increasing the oxalate will cause a decrease in excess acid.

\subsubsection{Qualification Elemental/Ion Analyses}

The following ten tables (Table 6 through 15) show general properties, anion concentrations, and elemental concentrations of the SRAT and SME products. Figure 14, in the Appendix, shows some ancillary data, and the $\mathrm{pH}$ profiles of the qualification runs. Of interest is the nitrite concentration measured for the low acid (100\% Koopman minimum acid) run; Table 8 shows that this value is $760 \mathrm{mg} / \mathrm{kg}$ slurry, which indicates a very low concentration. Thus, the Koopman minimum acid equation seems to have accurately predicted the amount of acid necessary to destroy nitrite. The anion chemistry, Table 9 , shows no unusual behavior.

Another noteworthy feature is that the high acid run exhibits the lowest mercury concentration in the slurry, about a third of the other three runs; this is true for both the SRAT and SME products. This behavior coincides with the unusually rapid decreases of the mercury time profile of SB6-G sludge. ${ }^{17}$ A later section will show similar time profile behavior of this work's SB7-A sludge. Note that in Table 8 the intermediate values of nitrite concentration were measured for the baseline and high oxalate runs (but not for the low and high acid runs). 
Table 6 Properties of Qualification SRAT Products

\begin{tabular}{|l|c|c|c|c|}
\hline & $\begin{array}{c}\text { SB7-1 } \\
\text { Low Acid }\end{array}$ & $\begin{array}{c}\text { SB7-2 } \\
\text { High Acid }\end{array}$ & $\begin{array}{c}\text { SB7-3 } \\
\text { Baseline Acid }\end{array}$ & $\begin{array}{c}\text { SB7-4 } \\
\text { High Oxalate }\end{array}$ \\
\hline Wt\% Total Solids & 25.2 & 23.5 & 24.5 & 24.8 \\
\hline Wt\% Insoluble Solids & 16.1 & 14.7 & 14.6 & 14.5 \\
\hline Wt\% Soluble Solids & 9.1 & 8.8 & 8.9 & 10.3 \\
\hline Wi\% Calcined Solids & 17.5 & 16.2 & 17.1 & 16.5 \\
\hline Slurry density, g/mL & 1.16 & 1.17 & 1.16 & 1.20 \\
\hline Supernate density, g/mL & 1.08 & 1.07 & 1.08 & 1.08 \\
\hline $\mathrm{pH}$ at $25^{\circ} \mathrm{C}$ & 8.0 & 8.8 & 8.9 & 8.7 \\
\hline $\mathrm{Wt} \% \mathrm{Hg}$, dried solids basis $\dagger$ & 0.070 & 0.024 & 0.072 & 0.062 \\
\hline
\end{tabular}

$\uparrow$ The mercury concentrations are uncertain (see section 3.1.4).

Table 7 Qualification SRAT Dewater Anions

\begin{tabular}{|l|c|c|c|c|}
\hline & $\begin{array}{c}\text { SB7-1 } \\
\text { Low Acid }\end{array}$ & $\begin{array}{c}\text { SB7-2 } \\
\text { High Acid }\end{array}$ & $\begin{array}{c}\text { SB7-3 } \\
\text { Baseline Acid }\end{array}$ & $\begin{array}{c}\text { SB7-4 } \\
\text { High Oxalate }\end{array}$ \\
\hline Nitrite, mg/L & 220 & $<100$ & 116 & $<100$ \\
\hline Nitrate, $\mathrm{mg} / \mathrm{L}$ & 3,250 & 701 & 3,450 & 3,410 \\
\hline Formate, $\mathrm{mg} / \mathrm{L}$ & 292 & 3,075 & 293 & 174 \\
\hline Sulfate, $\mathrm{mg} / \mathrm{L}$ & $<100$ & $<100$ & $<100$ & $<100$ \\
\hline Chloride, $\mathrm{mg} / \mathrm{L}$ & $<100$ & $<100$ & $<100$ & $<100$ \\
\hline
\end{tabular}

Oxalate values are not listed in this work because the method involving weighted dilution with water, which is not effective at dissolving certain insoluble oxalate species such as calcium oxalate, yield inaccurate lower bounds on the amount of oxalate in the SRAT product rather than an actual measurement of the total oxalate present. Attempts to use the acid spike method, ${ }^{18}$ the same as used in SB3 flowsheet studies, to obtain more accurate oxalate concentrations yielded values that were too great. The SB3 work also suffered from these problems ${ }^{19}$ and more work is needed to rectify this uncertainty. Nonetheless, despite the uncertainty, some useful information might still be obtained from other measurements of SB7-4.

SB7-4 nitrite levels indicate, as compared to the baseline, that increasing the oxalate seems to retard or diminish the ability of the nitrite consumption. It will be seen in a later section that the high oxalate run also exhibits a lower hydrogen generation. It can be concluded that oxalate consumes acid. 
Table 8 Qualification SRAT Product Anions

\begin{tabular}{|l|c|c|c|c|}
\hline & $\begin{array}{c}\text { SB7-1 } \\
\text { Low Acid }\end{array}$ & $\begin{array}{c}\text { SB7-2 } \\
\text { High Acid }\end{array}$ & $\begin{array}{c}\text { SB7-3 } \\
\text { Baseline Acid }\end{array}$ & $\begin{array}{c}\text { SB7-4 } \\
\text { High Oxalate }\end{array}$ \\
\hline Intermediate Nitrite & N/A & N/A & $<100$ & 612 \\
\hline Nitrite, $\mathrm{mg} / \mathrm{kg}$ & 760 & $<100$ & $<100$ & 175 \\
\hline Nitrate, $\mathrm{mg} / \mathrm{kg}$ & 24,700 & 24,800 & 25,400 & 27,700 \\
\hline Formate, $\mathrm{mg} / \mathrm{kg}$ & 36,900 & 35,400 & 38,500 & 35,100 \\
\hline Sulfate, $\mathrm{mg} / \mathrm{kg}$ & 1,930 & 1,815 & 1,715 & 1,925 \\
\hline Chloride, $\mathrm{mg} / \mathrm{kg}$ & 259 & 194 & 263 & 235 \\
\hline
\end{tabular}

+ Intermediate values of $\mathrm{NO}_{2}$ concentration were measured after about $75 \%$ of the SRAT reflux had elapsed. These are lower bounds, since the samples were not caustic quenched.

Table 9 Qualification SRAT Anion Reactions

\begin{tabular}{|l|c|c|c|c|}
\hline & $\begin{array}{c}\text { SB7-1 } \\
\text { Low Acid }\end{array}$ & $\begin{array}{c}\text { SB7-2 } \\
\text { High Acid }\end{array}$ & $\begin{array}{c}\text { SB7-3 } \\
\text { Baseline Acid }\end{array}$ & $\begin{array}{c}\text { SB7-4 } \\
\text { High Oxalate }\end{array}$ \\
\hline Nitrite Loss \% & $93 \%$ & $100 \%$ & $100 \%$ & $98 \%$ \\
\hline Net Nitrite-to-Nitrate \% & $20 \%$ & $-20 \%$ & $14 \%$ & $11 \%$ \\
\hline Formate Loss $\%$ & $25 \%$ & $50 \%$ & $26 \%$ & $24 \%$ \\
\hline Formate Lost, g & 35 & 104 & 39 & 34 \\
\hline
\end{tabular}


Table 10 Calcined Elemental Composition, wt $\%$, of SRAT Products $\left(1100^{\circ} \mathrm{C}\right)$

\begin{tabular}{|c|c|c|c|c|}
\hline Element & $\begin{array}{c}\text { SB7-1 } \\
\text { Low Acid }\end{array}$ & $\begin{array}{c}\text { SB7-2 } \\
\text { High Acid }\end{array}$ & $\begin{array}{c}\text { SB7-3 } \\
\text { Baseline Acid }\end{array}$ & $\begin{array}{c}\text { SB7-4 } \\
\text { High Oxalate }\end{array}$ \\
\hline $\mathrm{Al}$ & 15.9 & 16.0 & 15.6 & 15.2 \\
\hline $\mathrm{Ba}$ & 0.116 & 0.11 & 0.10 & 0.09 \\
\hline $\mathrm{Ca}$ & 0.857 & 0.87 & 0.81 & 0.80 \\
\hline $\mathrm{Ce}$ & 0.139 & 0.14 & 0.15 & 0.14 \\
\hline $\mathrm{Cr}$ & 0.051 & 0.05 & 0.05 & 0.05 \\
\hline $\mathrm{Cu}$ & 0.042 & 0.03 & 0.05 & 0.04 \\
\hline $\mathrm{Fe}$ & 19.1 & 19.2 & 19.3 & 18.0 \\
\hline $\mathrm{K}$ & 0.118 & 0.12 & 0.11 & 0.12 \\
\hline $\mathrm{La}$ & 0.070 & 0.07 & 0.07 & 0.07 \\
\hline $\mathrm{Mg}$ & 0.350 & 0.35 & 0.38 & 0.34 \\
\hline $\mathrm{Mn}$ & 4.26 & 4.2 & 4.38 & 4.22 \\
\hline $\mathrm{Na}$ & 15.9 & 16.1 & 15.7 & 17.4 \\
\hline $\mathrm{Ni}$ & 2.84 & 2.72 & 3.42 & 3.21 \\
\hline $\mathrm{Pb}$ & 0.026 & 0.028 & 0.02 & $<0.01$ \\
\hline $\mathrm{Rh}$ & $<0.1$ & $<0.1$ & $<0.1$ & $<0.1$ \\
\hline $\mathrm{Ru}$ & $<0.1$ & $<0.1$ & $<0.1$ & $<0.1$ \\
\hline $\mathrm{S}$ & 0.388 & 0.40 & 0.40 & 0.37 \\
\hline $\mathrm{Si}$ & 2.09 & 2.1 & 1.83 & 1.75 \\
\hline $\mathrm{Ti}$ & 0.033 & 0.03 & 0.04 & 0.04 \\
\hline $\mathrm{Zn}$ & 0.046 & 0.05 & 0.05 & 0.04 \\
\hline $\mathrm{Zr}$ & 0.254 & 0.25 & 0.25 & 0.23 \\
\hline & & & & \\
\hline
\end{tabular}

Comparison of the SRAT supernate product concentrations of the baseline and high oxalate runs of Table 11 reveals: a) decreased $\mathrm{Ca}$ and $\mathrm{Mg}$ concentrations in the high oxalate, b) stable $\mathrm{Mn}$ level, c) only a slightly higher $\mathrm{Na}$ concentration, and d) a greater $\mathrm{Ni}$ concentration. It would appear that the oxalate is causing $\mathrm{Ca}$ and $\mathrm{Mg}$ to form insoluble compounds either directly by attachment to oxalate or indirectly with some other anion. The reason for the enhancement of $\mathrm{Ni}$ solubility is not understood. Based on the SB7-Q recipe and on the amount of sodium oxalate added for the high oxalate run, the sodium concentration of the high oxalate run in the SRAT calcined measurement should be about $20 \%$ higher than in the other runs but Table 10 shows more modest differences, at most $10 \%$.

The sodium concentration of SB7-4 is higher due to the addition of sodium oxalate to the feed slurry for this test. The expected increase was roughly $3 \%(15.9$ to $18.9 \%)$, but the measured increase was smaller. 
Table 11 Elemental Composition SRAT Product Supernate

\begin{tabular}{|c|c|c|c|c|}
\hline Element & $\begin{array}{c}\text { SB7-1 } \\
\text { Low Acid } \\
\mathbf{m g} / \mathbf{L}\end{array}$ & $\begin{array}{c}\text { SB7-2 } \\
\text { High Acid } \\
\mathbf{m g} / \mathbf{L}\end{array}$ & $\begin{array}{c}\text { SB7-3 } \\
\text { Baseline } \\
\text { Acid, mg/L }\end{array}$ & $\begin{array}{c}\text { SB7-4 } \\
\text { High Oxalate } \\
\text { mg/L }\end{array}$ \\
\hline $\mathrm{Al}$ & 1.69 & 1.81 & 1.55 & 1.13 \\
\hline $\mathrm{B}$ & 2.09 & 5.85 & 1.89 & 1.19 \\
\hline $\mathrm{Ca}$ & 17.9 & 9.34 & 9.65 & 4.46 \\
\hline $\mathrm{Ce}$ & 0.384 & 0.344 & 0.400 & 0.457 \\
\hline $\mathrm{Cr}$ & $<0.1$ & $<0.1$ & $<0.1$ & $<0.1$ \\
\hline $\mathrm{Cu}$ & 0.874 & 0.848 & 0.163 & 0.598 \\
\hline $\mathrm{Fe}$ & $<0.1$ & $<0.1$ & $<1$ & $<1$ \\
\hline $\mathrm{K}$ & 483 & 418 & 436 & 395 \\
\hline $\mathrm{Li}$ & $<0.1$ & $<0.1$ & $<10$ & $<10$ \\
\hline $\mathrm{Mg}$ & 60.7 & 112 & 113 & 39.8 \\
\hline $\mathrm{Mn}$ & 328 & 486 & 845 & 667 \\
\hline $\mathrm{Ni}$ & 3.40 & 1.91 & 3.35 & 43.6 \\
\hline $\mathrm{S}$ & 789 & 785 & 871 & 991 \\
\hline $\mathrm{Si}$ & 19.5 & 29.2 & 15.0 & 13.0 \\
\hline $\mathrm{Sn}$ & 0.508 & 0.499 & 0.785 & 0.759 \\
\hline $\mathrm{Ti}$ & $<0.1$ & $<0.1$ & 0.193 & 0.169 \\
\hline $\mathrm{Zn}$ & $<0.1$ & $<0.1$ & $<0.1$ & $<0.1$ \\
\hline $\mathrm{Zr}$ & $<0.1$ & $<0.1$ & $<0.1$ & $<0.1$ \\
\hline
\end{tabular}

Table 12 Properties of Qualification SME Products

\begin{tabular}{|l|c|c|c|c|}
\hline & $\begin{array}{c}\text { SB7-1 } \\
\text { Low Acid }\end{array}$ & $\begin{array}{c}\text { SB7-2 } \\
\text { High Acid }\end{array}$ & $\begin{array}{c}\text { SB7-3 } \\
\text { Baseline }\end{array}$ & $\begin{array}{c}\text { SB7-4 } \\
\text { High Oxalate }\end{array}$ \\
\hline $\mathrm{W} \mathrm{t} \%$ Total Solids & 49.8 & 47.7 & 48.1 & 48.5 \\
\hline $\mathrm{W} \%$ Insoluble Solids & 41.3 & 39.3 & 39.3 & 39.1 \\
\hline $\mathrm{W} \%$ Soluble Solids & 8.6 & 8.4 & 8.8 & 9.5 \\
\hline $\mathrm{W} \%$ Calcined Solids & 43.0 & 41.1 & 41.7 & 41.4 \\
\hline Slurry density, $\mathrm{g} / \mathrm{mL}$ & 1.43 & 1.40 & 1.42 & 1.40 \\
\hline Supernate density, g/mL & 1.10 & 1.10 & 1.09 & 1.10 \\
\hline $\mathrm{pH}$ at $25^{\circ} \mathrm{C}$ & 7.7 & 8.2 & 8.3 & 8.4 \\
\hline $\mathrm{W} \mathrm{t} \% \mathrm{Hg}$ dried solids basis & 0.020 & 0.014 & 0.035 & 0.037 \\
\hline
\end{tabular}

Table 13 Qualification SME Product Anions

\begin{tabular}{|l|c|c|c|c|}
\hline & $\begin{array}{c}\text { SB7-1 } \\
\text { Low Acid }\end{array}$ & $\begin{array}{c}\text { SB7-2 } \\
\text { High Acid }\end{array}$ & $\begin{array}{c}\text { SB7-3 } \\
\text { Baseline }\end{array}$ & $\begin{array}{c}\text { SB7-4 } \\
\text { High Oxalate }\end{array}$ \\
\hline Nitrite, $\mathrm{mg} / \mathrm{kg}$ & 372 & $<100$ & $<100$ & $<100$ \\
\hline Nitrate, $\mathrm{mg} / \mathrm{kg}$ & 21,150 & 22,000 & 20,950 & 24,800 \\
\hline Formate, $\mathrm{mg} / \mathrm{kg}$ & 34,100 & 33,850 & 33,850 & 33,750 \\
\hline Sulfate, $\mathrm{mg} / \mathrm{kg}$ & 1,860 & 1,720 & 1,525 & 1,740 \\
\hline Chloride, $\mathrm{mg} / \mathrm{kg}$ & 272 & 216 & 234 & 216 \\
\hline
\end{tabular}


The SME elemental data for both the calcined and supernate phases are given below in Table 14 and Table 15. Frit 418 was used in all demonstrations. The actual waste loading for all four qualification runs varied from $35.4 \%$ to $35.7 \%$ and the flowsheet waste loading values varied from $34.9 \%$ to $36.0 \%$. These values agree well with each other and with the target waste loading of $36 \%$; thus, there was good control over the waste loading.

Table 14 Calcined Elemental Composition, wt $\%$, of SME Products $\left(1100^{\circ} \mathrm{C}\right)$

\begin{tabular}{|c|c|c|c|c|}
\hline Element & $\begin{array}{c}\text { SB7-1 } \\
\text { Low Acid }\end{array}$ & $\begin{array}{c}\text { SB7-2 } \\
\text { High Acid }\end{array}$ & $\begin{array}{c}\text { SB7-3 } \\
\text { Baseline }\end{array}$ & $\begin{array}{c}\text { SB7-4 } \\
\text { High Oxalate }\end{array}$ \\
\hline $\mathrm{Al}$ & 5.94 & 6.15 & 6.09 & 5.74 \\
\hline $\mathrm{B}$ & 1.42 & 1.44 & 1.49 & 1.41 \\
\hline $\mathrm{Ba}$ & 0.046 & 0.045 & 0.039 & 0.036 \\
\hline $\mathrm{Ca}$ & 0.460 & 0.392 & 0.351 & 0.334 \\
\hline $\mathrm{Ce}$ & 0.043 & 0.045 & 0.052 & 0.048 \\
\hline $\mathrm{Cr}$ & 0.035 & 0.037 & 0.033 & 0.027 \\
\hline $\mathrm{Cu}$ & 0.036 & 0.034 & 0.024 & 0.037 \\
\hline $\mathrm{Fe}$ & 6.99 & 6.93 & 6.95 & 6.49 \\
\hline $\mathrm{K}$ & 0.085 & 0.079 & 0.078 & 0.076 \\
\hline $\mathrm{La}$ & 0.028 & 0.029 & 0.023 & 0.022 \\
\hline $\mathrm{Li}$ & 2.19 & 2.25 & 2.22 & 2.19 \\
\hline $\mathrm{Mg}$ & 0.143 & 0.152 & 0.152 & 0.140 \\
\hline $\mathrm{Mn}$ & 1.42 & 1.49 & 1.58 & 1.45 \\
\hline $\mathrm{Na}$ & 9.87 & 9.81 & 9.52 & 9.99 \\
\hline $\mathrm{Ni}$ & 1.13 & 1.18 & 1.22 & 1.17 \\
\hline $\mathrm{Pb}$ & 0.014 & 0.012 & 0.012 & 0.012 \\
\hline $\mathrm{Rh}$ & $<0.1$ & $<0.1$ & $<0.1$ & $<0.1$ \\
\hline $\mathrm{Ru}$ & $<0.1$ & $<0.1$ & $<0.1$ & $<0.1$ \\
\hline $\mathrm{S}$ & 0.175 & 0.142 & 0.118 & 0.124 \\
\hline $\mathrm{Si}$ & 23.5 & 24.0 & 23.9 & 23.7 \\
\hline $\mathrm{Ti}$ & 0.064 & 0.068 & 0.061 & 0.054 \\
\hline $\mathrm{Zn}$ & 0.026 & 0.035 & 0.019 & 0.018 \\
\hline $\mathrm{Zr}$ & 0.192 & 0.195 & 0.185 & 0.174 \\
\hline & & & & \\
\hline
\end{tabular}

The SME product calcined elemental values indicate that sodium concentration level in SB7-4 is only slightly higher than those of the other runs; this is also the case for the SRAT products. The reasons for this are unknown, since the sodium oxalate addition to SB7-4 should have produced an increase of roughly one percent compared to SB $7-1$ through $3(9.7 \%$ to $10.9 \%)$. 
Table 15 Elemental Composition of Qualification SME Supernate Products

\begin{tabular}{|c|c|c|c|c|}
\hline Element & $\begin{array}{c}\text { SB7-1 } \\
\text { Low Acid } \\
\mathbf{m g} / \mathbf{L}\end{array}$ & $\begin{array}{c}\text { SB7-2 } \\
\text { High Acid } \\
\mathbf{m g} / \mathbf{L}\end{array}$ & $\begin{array}{c}\text { SB7-3 } \\
\text { Baseline } \\
\text { Acid, mg/L }\end{array}$ & $\begin{array}{c}\text { SB7-4 } \\
\text { High Oxalate } \\
\mathbf{m g} / \mathbf{L}\end{array}$ \\
\hline $\mathrm{Al}$ & 1.76 & 1.61 & 1.26 & 1.55 \\
\hline $\mathrm{B}$ & 35.3 & 17.2 & 13.6 & 41.6 \\
\hline $\mathrm{Ca}$ & 32.3 & 30.7 & 16.4 & 5.33 \\
\hline $\mathrm{Ce}$ & 1.53 & 1.51 & 0.604 & 1.14 \\
\hline $\mathrm{Cr}$ & $<0.1$ & $<0.1$ & $<0.1$ & $<0.1$ \\
\hline $\mathrm{Cu}$ & 1.63 & 0.857 & 0.263 & 0.278 \\
\hline $\mathrm{Fe}$ & $<0.1$ & $<0.1$ & $<1$ & $<1$ \\
\hline $\mathrm{K}$ & 615 & 595 & 550 & 504 \\
\hline $\mathrm{Li}$ & $<0.1$ & $<0.1$ & 244 & 327 \\
\hline $\mathrm{Mg}$ & 177 & 232 & 151 & 32.7 \\
\hline $\mathrm{Mn}$ & 1760 & 1855 & 1211 & 930 \\
\hline $\mathrm{Ni}$ & 21.2 & 7.10 & 6.70 & 38.4 \\
\hline $\mathrm{Rh}$ & $<1$ & $<1$ & $<1$ & 1.32 \\
\hline $\mathrm{Ru}$ & $<1$ & $<1$ & $<1$ & $<1$ \\
\hline $\mathrm{S}$ & 1080 & 1225 & 1222 & 1253 \\
\hline $\mathrm{Si}$ & 21.6 & 38.6 & 18.1 & 17.3 \\
\hline $\mathrm{Sn}$ & 2.70 & 2.40 & 1.40 & 1.24 \\
\hline $\mathrm{Ti}$ & $<0.1$ & $<0.1$ & 0.182 & 0.166 \\
\hline $\mathrm{Zn}$ & $<0.1$ & $<0.1$ & $<0.1$ & $<0.1$ \\
\hline $\mathrm{Zr}$ & $<0.1$ & $<0.1$ & $<0.1$ & $<0.1$ \\
\hline & & & & \\
\hline
\end{tabular}

\subsubsection{Qualification GC Results}

The qualification runs did not exceed hydrogen peak generation rate limits, 0.65 and $0.223 \mathrm{lb} / \mathrm{hr}$ for the SRAT and SME cycles, respectively. Table 16 shows the peak gas generation rates as measured by the GC during the SRAT cycles. More detailed GC time profiles are shown in Figures 2,3, and 4. Since these figures are congested and do not show the SME data as clearly, SME-only data are given in the Appendix; see Figures 16-18. Hydrogen production was highest for the highest acid run, as expected. The next highest producer of hydrogen was the baseline run, at $110 \%$ acid level. The high oxalate run produced less hydrogen than the baseline: All runs exhibit similar peak $\mathrm{CO}_{2}$ rates. The nitrous oxide rates are similar and relatively high for the high acid and baseline runs but are low for the low acid and high oxalate cases. Based on the behavior of SB7 4 , less hydrogen generated and less nitrite destroyed, it is apparent that oxalate consumes acid.

Table 16 Maximum SRAT Gas Generation Rates

\begin{tabular}{|l|c|c|c|c|}
\hline \multicolumn{1}{|c|}{ Gas } & $\begin{array}{c}\text { SB7-1 } \\
\text { Low Acid }\end{array}$ & $\begin{array}{c}\text { SB7-2 } \\
\text { High Acid }\end{array}$ & $\begin{array}{c}\text { SB7-3 } \\
\text { Baseline } \\
\text { Acid }\end{array}$ & $\begin{array}{c}\text { SB7-4 } \\
\text { High Oxalate }\end{array}$ \\
\hline $\mathrm{H}_{2}, \mathrm{lb} / \mathrm{hr}$ & 0.00 & 0.52 & 0.034 & 0.00 \\
\hline $\mathrm{N}_{2} \mathrm{O}, \mathrm{lb} / \mathrm{hr}$ & 19.1 & 29.5 & 30.8 & 18.4 \\
\hline $\mathrm{CO}_{2}, \mathrm{lb} / \mathrm{hr}$ & 543 & 545 & 490 & 509 \\
\hline
\end{tabular}


Table 17 contains the SME gas generation rates. The SME hydrogen generation trends are similar to those of the SRAT: greatest value from the high acid run and the lowest from the low acid and high oxalate cases. However, there is more variation in $\mathrm{CO}_{2}$ and $\mathrm{N}_{2} \mathrm{O}$ production (than in the SRAT cycle). The high acid yielded the greatest $\mathrm{CO}_{2}$ generation while the low acid and high oxalate runs yielded the least. $\mathrm{N}_{2} \mathrm{O}$ production was different in that the high acid run produced none of the gas while the high oxalate and baseline runs produced the most.

Table 17 Maximum SME Gas Generation Rates

\begin{tabular}{|l|c|c|c|c|}
\hline \multicolumn{1}{|c|}{ Gas } & $\begin{array}{c}\text { SB7-1 } \\
\text { Low Acid }\end{array}$ & $\begin{array}{c}\text { SB7-2 } \\
\text { High Acid }\end{array}$ & $\begin{array}{c}\text { SB7-3 } \\
\text { Baseline }\end{array}$ & $\begin{array}{c}\text { SB7-4 } \\
\text { High Oxalate }\end{array}$ \\
\hline $\mathrm{H}_{2}, \mathrm{lb} / \mathrm{hr}$ & 0.002 & 0.18 & 0.14 & 0.02 \\
\hline $\mathrm{N}_{2} \mathrm{O}, \mathrm{lb} / \mathrm{hr}$ & 0.35 & 0.00 & 1.10 & 0.87 \\
\hline $\mathrm{CO}_{2}, \mathrm{lb} / \mathrm{hr}$ & 22.2 & 134 & 48.3 & 22.6 \\
\hline
\end{tabular}

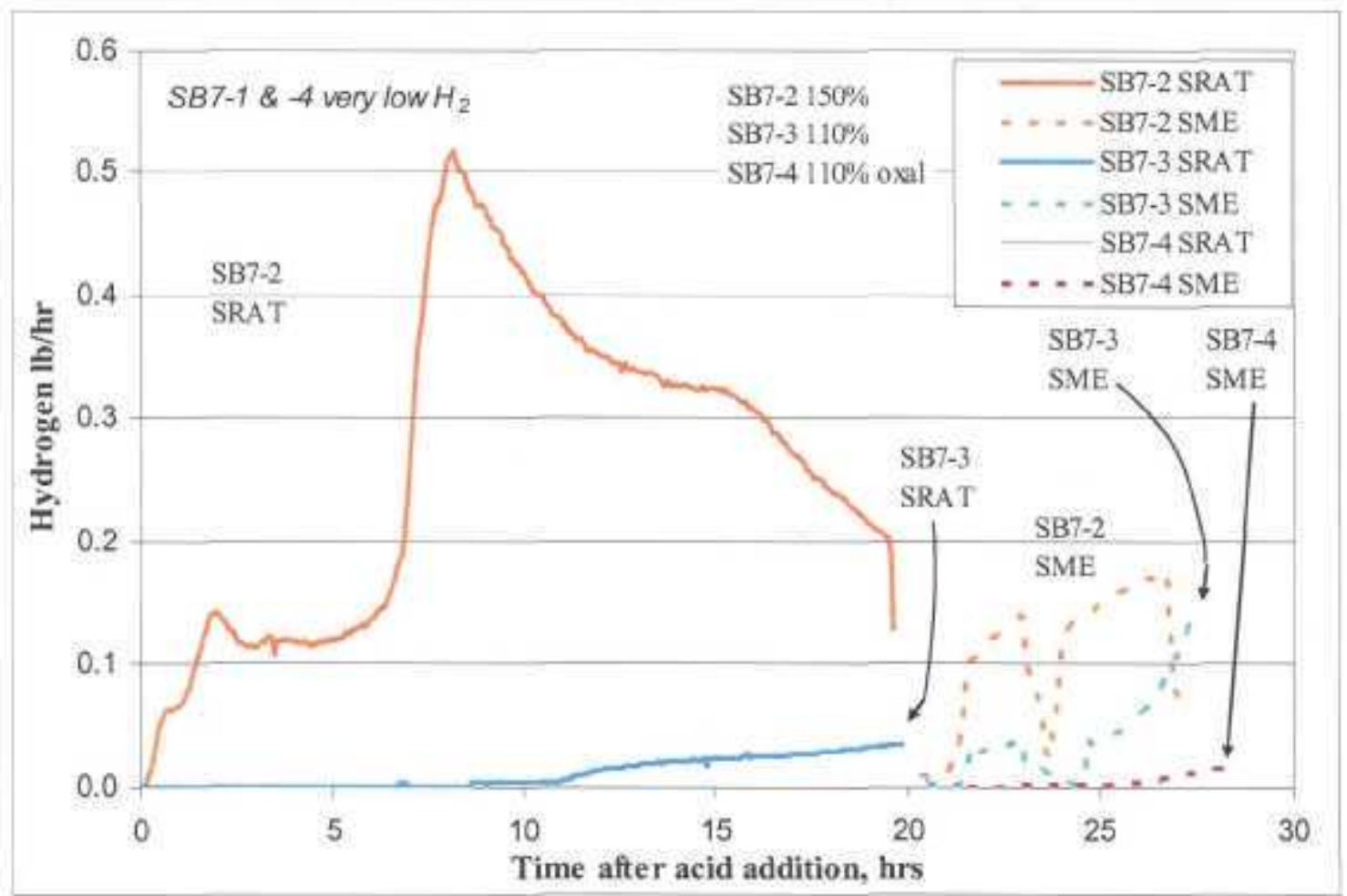

Figure 2 Qualification SRAT/SME Hydrogen Profiles

Both $\mathrm{CO}_{2}$ and $\mathrm{N}_{2} \mathrm{O}$ production are greater in the high acid run, Figures 3 and 4 . The secondary humps between 5 and 10 hours after the end of acid addition coincide for all three gases. 


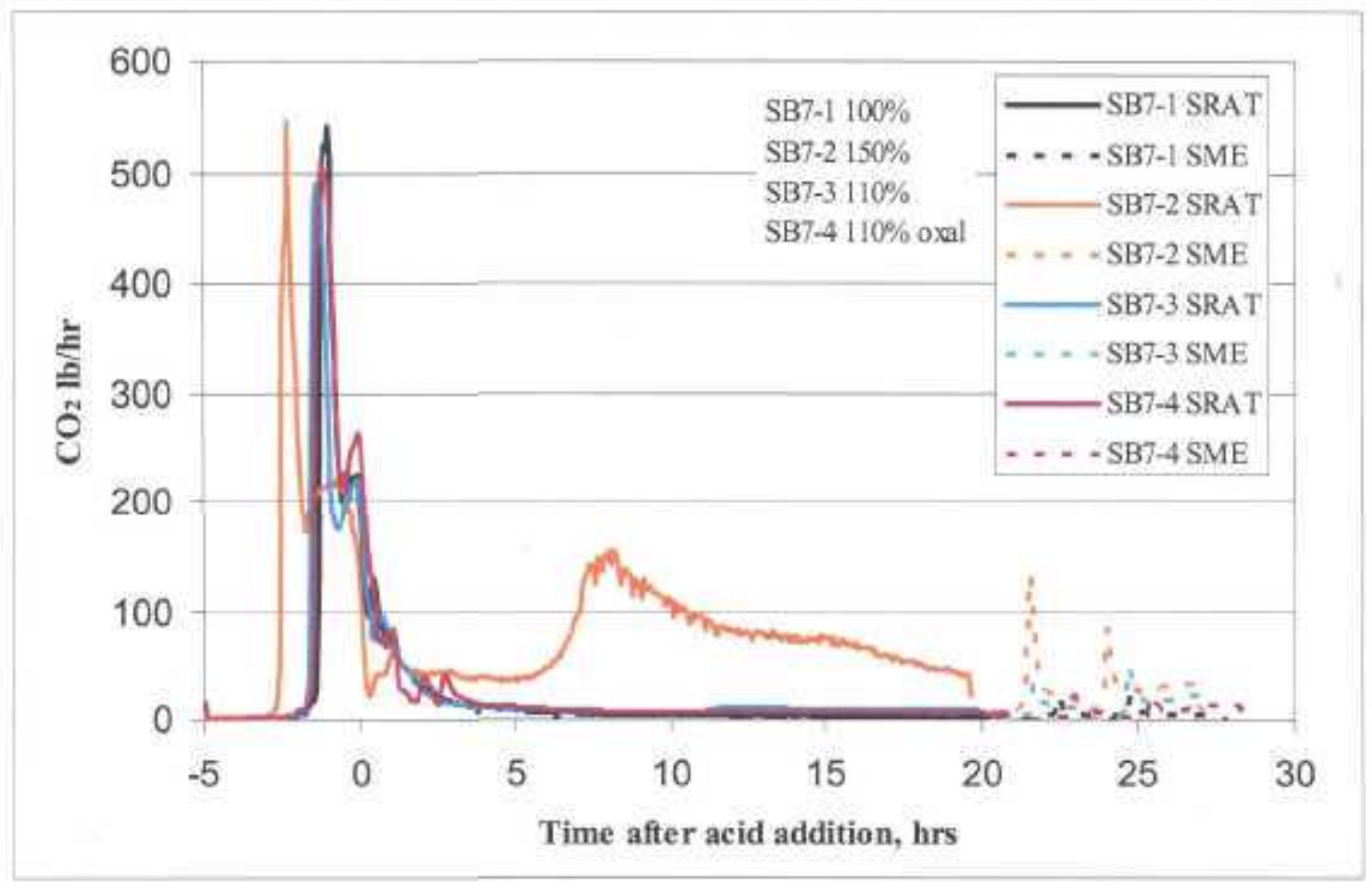

Figure 3 Qualification SRAT/SME $\mathrm{CO}_{2}$ Profiles

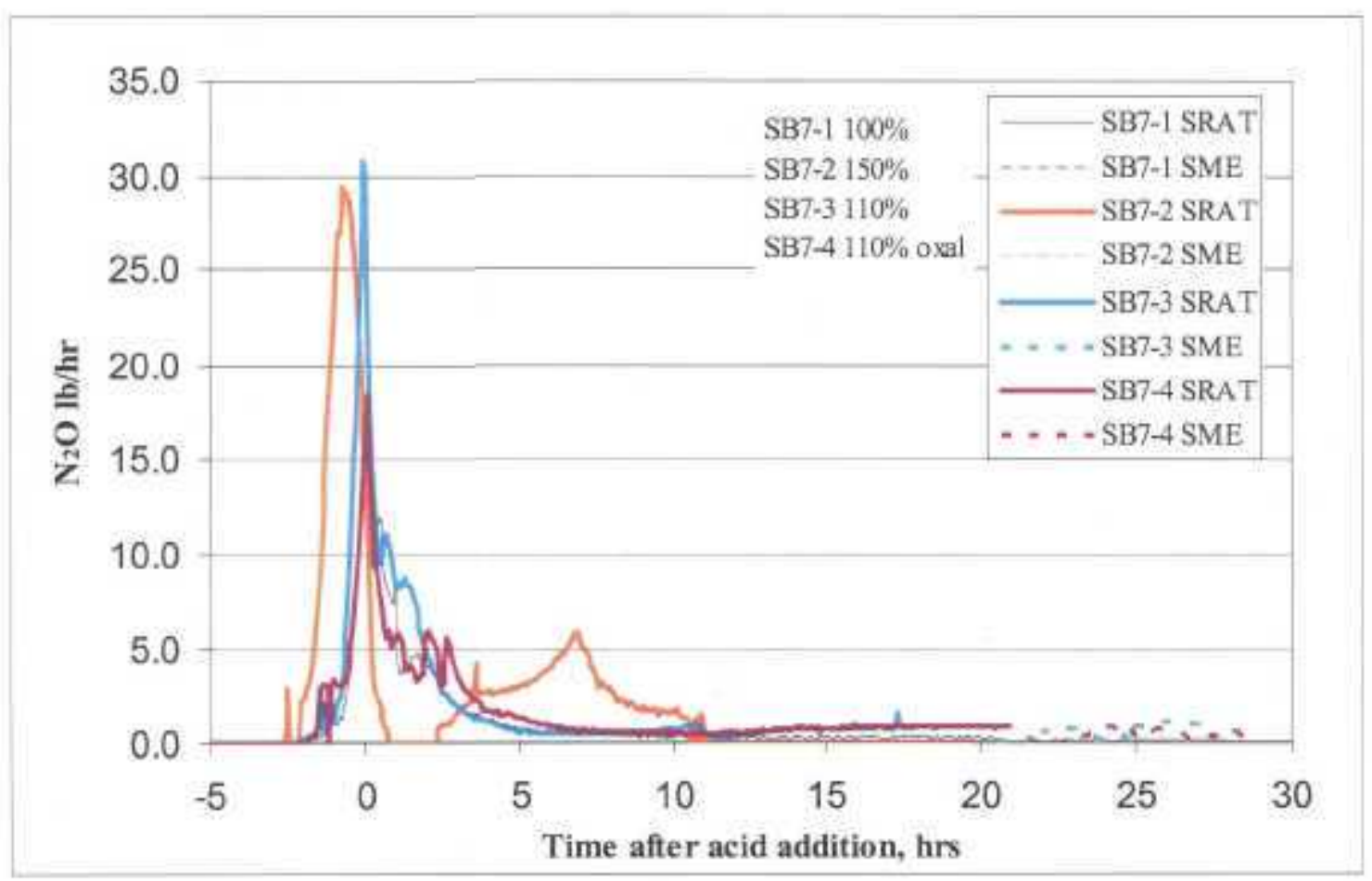

Figure 4 Qualification SRAT/SME $\mathrm{N}_{2} \mathrm{O}$ Profiles 


\subsubsection{Qualification Ammonia/Ammonium Results}

The available data of ammonia and ammonium generation, the former measured in the outlet of the SRAT condenser and the latter captured in the ammonia scrubber liquid, are sparse but indicate nonetheless that limited excess acid tends to prevent generation of these two species. The gas measurement of the baseline run was performed at an earlier time than the others but there is likely to be little interference from $\mathrm{NO}_{x}$ since the $\mathrm{GC}$ data in Figure 4 shows that the $\mathrm{N}_{2} \mathrm{O}$ concentration was low after five hours of reflux.

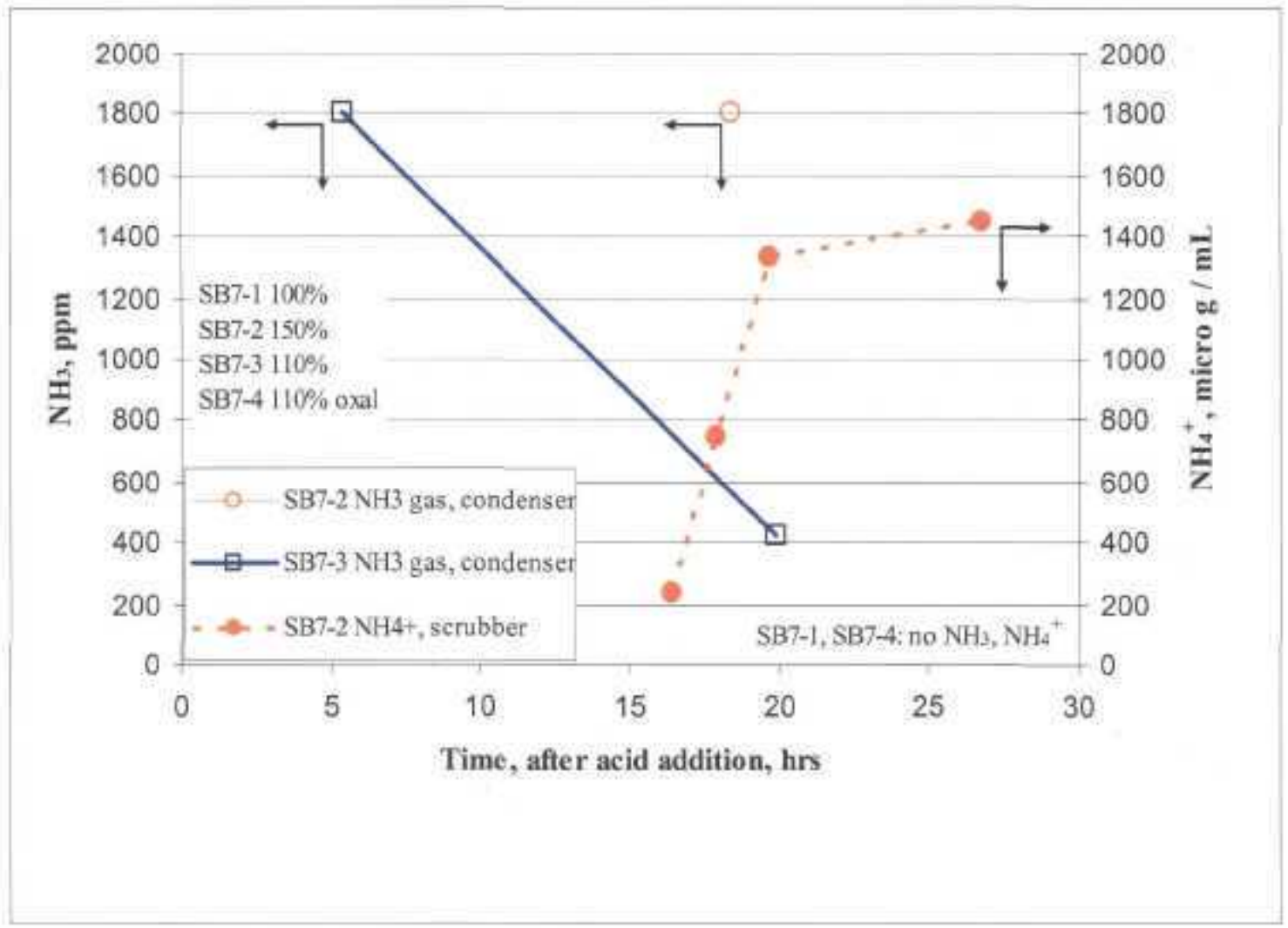

Figure 5 Qualification SRAT Ammonia and Ammonium Concentrations

\subsubsection{Qualification Mercury Results}

The concentration of mercury was measured via the sample taken from in the SRAT/SME kettle and in the gas phase at the outlet of the SRAT condenser; the MWWT was also used to collect $\mathrm{Hg}$. Mercury concentrations in the SRAT and SME product slurries are tabulated; see Table 18.

Table 18 Mercury Composition in Qualification SRAT/SME Slurries

\begin{tabular}{|l|c|c|c|c|}
\hline & $\begin{array}{c}\text { SB7-1 } \\
\text { Low Acid }\end{array}$ & $\begin{array}{c}\text { SB7-2 } \\
\text { High Acid }\end{array}$ & $\begin{array}{c}\text { SB7-3 } \\
\text { Baseline Acid }\end{array}$ & $\begin{array}{c}\text { SB7-4 } \\
\text { High Oxalate }\end{array}$ \\
\hline SRAT product, $\mathrm{Wt} \% \mathrm{Hg}$, dried solids & 0.070 & 0.024 & 0.072 & 0.062 \\
\hline SME product, $\mathrm{Wt} \% \mathrm{Hg}$, dried solids & 0.020 & 0.014 & 0.035 & 0.037 \\
\hline
\end{tabular}


Figure 6 shows the $\mathrm{Hg}$ time profile of all four qualification slurries; the same amount of mercury was trimmed into each of the runs. Note that the first values at the end of acid addition refer to a slumy before dewatering and thus are dilute relative to the rest of the data which correspond to sampling during SRAT reflux, i.e., after dewatering was completed. As mentioned above, the high acid run, SB7-2, shows a sudden drop in mercury concentration, consistent with SB6 behavior. ${ }^{17}$ However, the behavior of high oxalate run is even more puzzling; the initial concentration of mercury in the slurry of the high oxalate run is anomalously low. It should be about ten times greater since the same amount of mercury was trimmed in. The reason for this very low mercury concentration after the end of acid addition could be associated with the increase of oxalate which could catalyze the production and agglomeration of elemental mercury. Little was learned about the interactions between oxalate and mercury during the Sludge Batch 3 (SB3) testing, because SB3 sludge had a very low mercury concentration in the starting sludge, about thirty times less than the current mercury level.

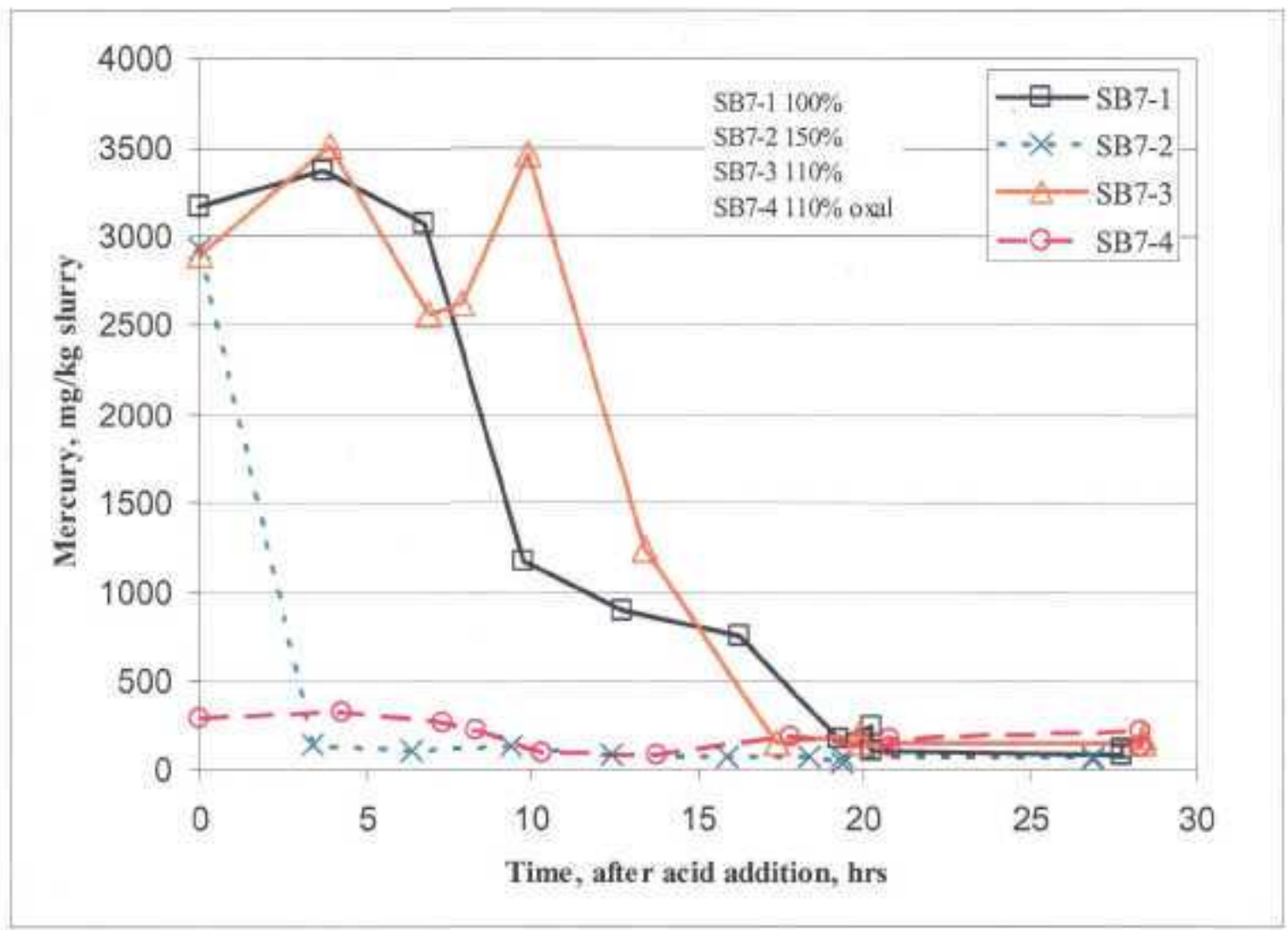

Figure 6 Qualification Slurry Mercury Measurements

Mercury gas measurements are shown in Figure 7; these measurements are too sparse to provide additional information than what is already shown in Table 6 , low acid and high oxalate tend to decrease $\mathrm{Hg}$ concentration in the kettle. The gas measurement of the baseline run was performed at an earlier time than the others but there is likely to be little interference from $\mathrm{NO}_{x}$ since the $\mathrm{GC}$ data in Figure 4 shows that the $\mathrm{N}_{2} \mathrm{O}$ concentration was low after five hours of reflux.

By comparing the slurry and gaseous mercury concentrations in Figures 6 and 7, the following observations are made: a) SB7-1 has a slow decrease in the slurry and a low gas concentration, b) 
SB7-2 shows a substantial gas concentration late in the reflux regime despite a very sudden and substantial decrease of the slurry mercury very early in the reflux, c) SB7-3 slurry concentrations slowly decrease while the gas increases substantially during the same time interval, and d) SB7-4 exhibits an end-of-acid slurry mercury concentration that is a factor of ten lower than the other runs but a gas concentration roughly equal to that of the low acid run. Due to the sparseness of the gas data and to the uncertainty in the slurry mercury levels, little more can be speculated.

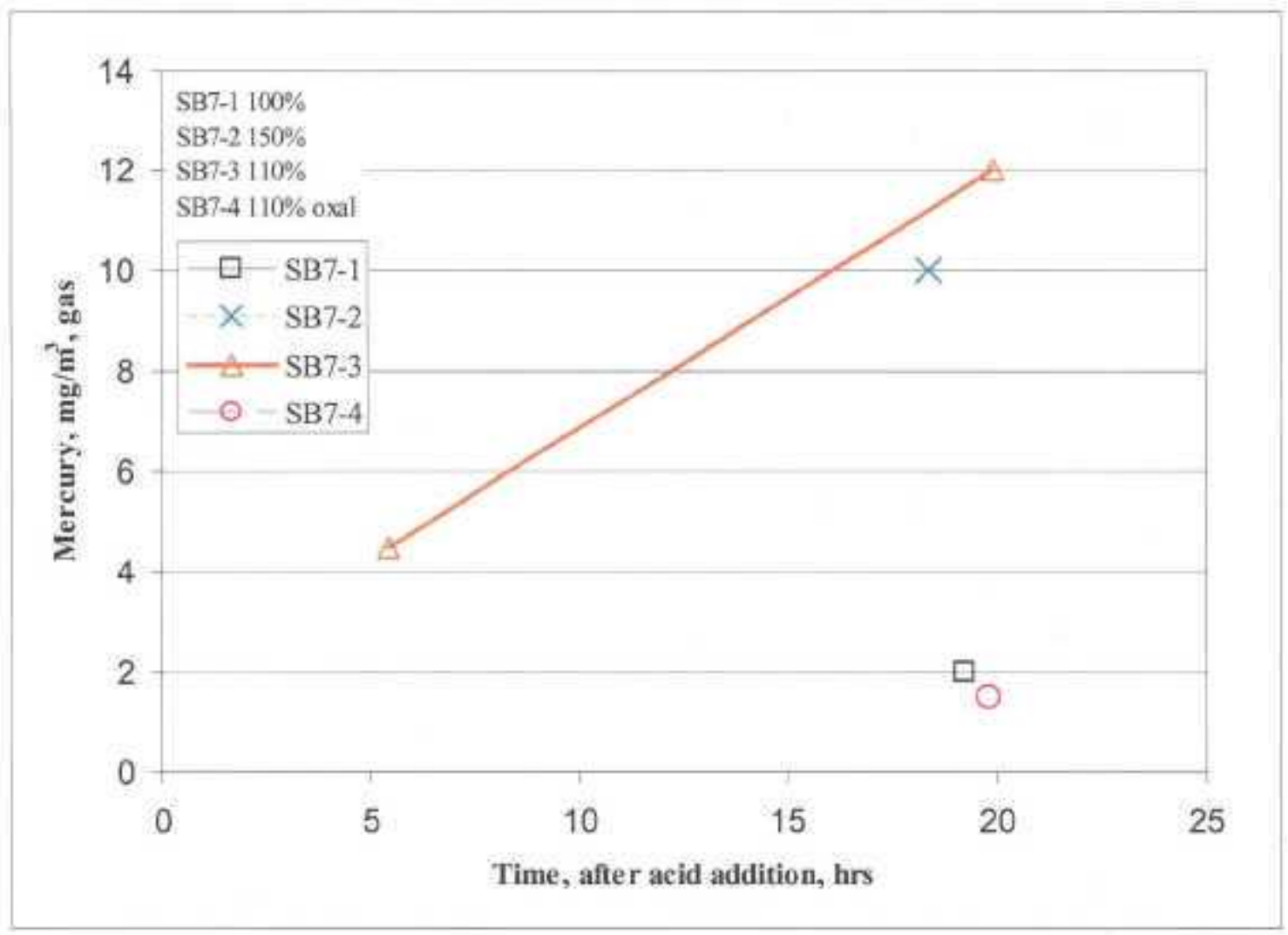

Figure 7 Qualification Gaseous Mercury Measurements

In order to understand the fate of mercury in the system, a mass balance is shown in Table 19. The last column indicates that more than half of the mercury is unaccounted for in each of the four runs. The average $\mathrm{Hg}$ gas concentration is listed and, taking into account the time interval and volumetric flow rate of the total off-gases, a very small mass was lost to off-gassing, several milligrams. The uncertainty of $\mathrm{Hg}$ gas concentration due to sparse data, Figure 7 , is thus irrelevant due to the small mass loss. Nonetheless, these estimated $\mathrm{Hg}$ gas masses are included in the calculation of missing $\mathrm{Hg}$ in Table 19. It can be speculated that the "missing mercury" was likely to have been in the SRAT/SME kettle. 
Table 19 Qualification Mercury Balance

\begin{tabular}{|c|c|c|c|c|c|c|c|}
\hline Run ID & $\begin{array}{c}\text { Hg } \\
\text { input, } \\
\text { g }\end{array}$ & $\begin{array}{c}\text { SRAT } \\
\text { Dewater } \\
\text { recovery, } \\
\text { Hg (aq), g }\end{array}$ & $\begin{array}{c}\text { SRAT } \\
\text { MWWT } \\
\text { recovery, g } \\
+\end{array}$ & $\begin{array}{c}\text { SME } \\
\text { product } \\
\text { recovery, } \\
\text { g }\end{array}$ & $\begin{array}{c}\text { Average } \\
{[\mathbf{H g}] \text { gas, }} \\
\text { mg/ m }\end{array}$ & $\begin{array}{c}\text { Total Hg } \\
\text { recovery, g }\end{array}$ & $\begin{array}{c}\text { Missing } \\
\mathbf{H g} \%\end{array}$ \\
\hline SB7-1 & 12.90 & 0.22 & 4.18 & 0.27 & 2 & 4.67 & 64 \\
\hline SB7-2 & 12.90 & 0.01 & 1.61 & 0.16 & 10 & 1.79 & 86 \\
\hline SB7-3 & 12.90 & 0.20 & 3.61 & 0.43 & 8 & 4.25 & 67 \\
\hline SB7-4 & 12.90 & 0.12 & 3.01 & 0.49 & 1.5 & 3.62 & 72 \\
\hline
\end{tabular}

† The $\mathrm{Hg}$ masses listed in the SRAT MWWT are from the solid phase only because the combination of low aqueous concentrations and low overall mass of the liquid make the dissolved $\mathrm{Hg}$ masses very low, less than $10 \mathrm{mg}$; nonetheless, though not listed, these masses have been used in the calculation of the total recovered $\mathrm{Hg}$.

More evidence that the missing mercury for SB7-2 was stuck in the kettle can be obtained by examining the mercury levels in the combined SRAT MWWT dewater condensate, Table 20. The high acid run demonstrates: a) a relatively low level of dissolved $\mathrm{Hg}$ in the SRAT MWWT dewater condensate, b) a relatively lower value of undissolved mercury in the MWWT at the end of the SRAT run (Table 19), and c) a very sudden and overwhelming decrease in SRAT slurry mercury (Figure 6) between the end of acid addition and the end of dewatering. If the mercury did not end up in the off-gas system, then it is likely that it remained in the vessel.

Table 20 Mercury Levels in Qualification Dewater Condensate

\begin{tabular}{|c|c|}
\hline Run ID & {$\left[\mathrm{Hg}_{\text {ar }} \mathbf{m g} / \mathbf{L}\right.$ condensate } \\
\hline SB7-1 & 223 \\
\hline SB7-2 & 12.9 \\
\hline SB7-3 & 222 \\
\hline SB7-4 & 155 \\
\hline
\end{tabular}

\subsubsection{Qualification Rheology}

Rheology measurements were obtained for both the SRAT products, Table 21, and SME products, Table 22. Figures 22 through 29 show the flow curves of the qualification SRAT and SME products. Because of time-dependence of some up curves, the down eurves were used to determine the rheological properties of the slurries. As expected the high acid qualification run, SB7-2, shows the smallest yield stress and consistency by the end of the SRAT cycle. The second thinnest SRAT product is the high oxalate run, SB7-4. The SRAT product with the highest yield stress is that of the baseline run, while the highest consistency is shown by the low acid run (though it's closely followed by the baseline run and the difference is negligible, within the uncertainty of the measurements). SB $7-4$ had the highest concentration of soluble solids, perhaps due to the additional oxalate, as well as having the lowest yield stress of the three low acid runs. 
Table 21 Qualification SRAT Products Rheology

\begin{tabular}{|l|c|c|c|c|}
\hline & $\begin{array}{c}\text { SB7-1 } \\
\text { Low Acid }\end{array}$ & $\begin{array}{c}\text { SB7-2 } \\
\text { High Acid }\end{array}$ & $\begin{array}{c}\text { SB7-3 } \\
\text { Baseline } \\
\text { Acid }\end{array}$ & $\begin{array}{c}\text { SB7-4 } \\
\text { High } \\
\text { Oxalate }\end{array}$ \\
\hline Yield Stress, Pa, Down & 2.9 & 1.4 & 3.3 & 2.2 \\
\hline Consistency, cP, Down & 12.7 & 4.7 & 12.6 & 9.9 \\
\hline Wt \% IS & 16.1 & 14.7 & 14.6 & 14.5 \\
\hline
\end{tabular}

The SME rheology, exhibits a somewhat different trend; this is not unusual since the addition of frit greatly affects the theology. The smallest yield stress still corresponds to the high acid run but the smallest consistency pertains to the high oxalate run. Like the SRAT products, the SME product with the highest yield stress is that of the baseline run while the highest consistency is shown by the low acid run. The reasons for this are unclear.

Table 22 Qualification SME Products Rheology

\begin{tabular}{|l|c|c|c|c|}
\hline & $\begin{array}{c}\text { SB7-1 } \\
\text { Low Acid }\end{array}$ & $\begin{array}{c}\text { SB7-2 } \\
\text { High Acid }\end{array}$ & $\begin{array}{c}\text { SB7-3 } \\
\text { Baseline } \\
\text { Acid }\end{array}$ & $\begin{array}{c}\text { SB7-4 } \\
\text { High } \\
\text { Oxalate }\end{array}$ \\
\hline Yield Stress, Pa, Down & 20 & 8.3 & 24 & 12.0 \\
\hline Consistency, cP, Down & 38 & 31 & 31 & 25 \\
\hline Wt \% IS & 41.3 & 39.3 & 39.3 & 39.1 \\
\hline
\end{tabular}

\subsection{Flowsheet CPC Simulation}

Five runs were performed for the flowsheet portion of this work, as identified by run numbers SB7-5 through SB7-9. Table 23 shows the acid stoichiometric factors and acid added.

Table 23 Flowsheet Runs Acid Levels

\begin{tabular}{|l|c|c|c|}
\hline \multicolumn{1}{|c|}{ Run ID - Function } & $\begin{array}{c}\text { Acid, } \\
\mathbf{m o l} / \mathbf{L}\end{array}$ & Hsu factor & KMA factor $\boldsymbol{~}$ \\
\hline SB7-5 - Low acid & 1.18 & $102 \%$ & $100 \%$ \\
\hline SB7-6 - High acid & 1.80 & $155 \%$ & $150 \%$ \\
\hline SB7-7 - ARP-MCU & 1.57 & $107 \%$ & $110 \%$ \\
\hline SB7-8 - Extended & 1.33 & $112 \%$ & $110 \%$ \\
\hline SB7-9 - Baseline Acid & 1.33 & $112 \%$ & $110 \%$ \\
\hline
\end{tabular}

$\uparrow$ Koopman minimum acid

\subsubsection{Flowsheet Elemental/Ion Analyses}

The following ten tables (Tables 24 through 33 ) show general properties, anion concentrations, and elemental concentrations of the SRAT and SME products. Figure 15, in the Appendix, shows some ancillary data, the $\mathrm{pH}$ profiles of the flowsheet runs. Of interest is the "intermediate" nitrite concentration measured for the low acid ( $100 \%$ Koopman minimum acid) run; Table 26 shows that this value is $472 \mathrm{mg} / \mathrm{kg}$ slurry, which indicates a very low concentration and by the end of the 
SRAT cycle the nitrite was consumed. Thus, the Koopman minimum acid equation again (see qualification case above) seems to have accurately predicted the amount of acid necessary to destroy nitrite. The other SRAT products, including the low acid one show complete destruction of nitrite. The anion chemistry, Table 27 , shows no unusual behavior.

Another noteworthy feature is that the high acid run exhibits the lowest mercury concentration in the slurry, roughly half of some other runs; this is true for both the SRAT and SME products for both the flowsheet and qualification (see above) runs. Again, this behavior coincides with the unusually rapid decreases of the mercury time profile of SB6-G sludge. ${ }^{1}$ A later section will show similar time profile behavior of this work's SB7-Q and SB7-A sludges.

Table 24 Properties of Flowsheet SRAT Products

\begin{tabular}{|l|c|c|c|c|c|}
\hline & $\begin{array}{c}\text { SB7-5 } \\
\text { Low } \\
\text { Acid }\end{array}$ & $\begin{array}{c}\text { SB7-6 } \\
\text { High } \\
\text { Acid }\end{array}$ & $\begin{array}{c}\text { SB7-7 } \\
\text { ARP-SRAT } \\
\text { Products }\end{array}$ & $\begin{array}{c}\text { SB7-8 } \\
\text { Extended }\end{array}$ & $\begin{array}{c}\text { SB7-9 } \\
\text { Baseline } \\
\text { Acid }\end{array}$ \\
\hline Wt\% Total Solids & 24.5 & 23.7 & 25.7 & 24.2 & 23.9 \\
\hline Wt $\%$ Insoluble Solids & 15.8 & 14.7 & 15.4 & 15.6 & 14.4 \\
\hline Wt $\%$ Soluble Solids & 8.7 & 9.0 & 10.3 & 8.6 & 9.5 \\
\hline Wt\% Calcined & 17.1 & 15.8 & 17.6 & 17.1 & 16.7 \\
\hline Slurry density, g/mL & 1.14 & 1.18 & 1.19 & 1.14 & 1.11 \\
\hline Supernate density, g/mL & 1.07 & 1.07 & 1.08 & 1.07 & 1.07 \\
\hline pH at $25^{\circ} \mathrm{C}$ & 8.3 & 7.9 & 7.6 & 8.6 & 7.9 \\
\hline $\mathrm{Wt} \% \mathrm{Hg}$, solids basis $\dagger$ & 0.042 & 0.021 & - & 0.123 & 0.040 \\
\hline
\end{tabular}

$\uparrow$ The mercury concentrations are uncertain (see section 3.2.4).

Table 25 Flowsheet SRAT Dewater Anions

\begin{tabular}{|l|c|c|c|c|c|}
\hline & $\begin{array}{c}\text { SB7-5 } \\
\text { Low Acid }\end{array}$ & $\begin{array}{c}\text { SB7-6 } \\
\text { High } \\
\text { Acid }\end{array}$ & $\begin{array}{c}\text { SB7-7 } \\
\text { ARP-SME } \\
\text { Products }\end{array}$ & $\begin{array}{c}\text { SB7-8 } \\
\text { Extended }\end{array}$ & $\begin{array}{c}\text { SB7-9 } \\
\text { Baseline } \\
\text { Acid }\end{array}$ \\
\hline Nitrite, $\mathrm{mg} / \mathrm{L}$ & $<100$ & $<100$ & $<100$ & $<100$ & $<100$ \\
\hline Nitrate, $\mathrm{mg} / \mathrm{L}$ & 4360 & 2430 & 5410 & 3620 & 4495 \\
\hline Formate, $\mathrm{mg} / \mathrm{L}$ & 205 & $<100$ & 260 & 234.5 & 249.5 \\
\hline Sulfate, $\mathrm{mg} / \mathrm{L}$ & $<100$ & $<100$ & $<100$ & $<100$ & $<100$ \\
\hline Chloride, $\mathrm{mg} / \mathrm{L}$ & $<100$ & $<100$ & $<100$ & $<100$ & $<100$ \\
\hline
\end{tabular}


Table 26 Flowsheet SRAT Product Anions

\begin{tabular}{|l|c|c|c|c|c|}
\hline & $\begin{array}{c}\text { SB7-5 } \\
\text { Low } \\
\text { Acid }\end{array}$ & $\begin{array}{c}\text { SB7-6 } \\
\text { High } \\
\text { Acid }\end{array}$ & $\begin{array}{c}\text { SB7-7 } \\
\text { ARP-SRAT } \\
\text { Products }\end{array}$ & $\begin{array}{c}\text { SB7-8 } \\
\text { Extended }\end{array}$ & $\begin{array}{c}\text { SB7-9 } \\
\text { Baseline } \\
\text { Acid }\end{array}$ \\
\hline Intermediate Nitrite & 472 & $<100$ & $<100 \ddagger$ & $<100$ & $<100$ \\
\hline Nitrite, $\mathrm{mg} / \mathrm{kg}$ & $<100$ & $<100$ & $<100$ & $<100$ & $<100$ \\
\hline Formate, $\mathrm{mg} / \mathrm{kg}$ & 36,750 & 42,050 & 43,850 & 36,400 & 38,050 \\
\hline Nitrate, $\mathrm{mg} / \mathrm{kg}$ & 20,100 & 23,850 & 23,450 & 21,850 & 22,700 \\
\hline Sulfate, $\mathrm{mg} / \mathrm{kg}$ & 1,250 & 1,170 & 2,290 & 1,310 & 1,155 \\
\hline Chloride, $\mathrm{mg} / \mathrm{kg}$ & 307 & 250 & 488 & 324 & 307 \\
\hline
\end{tabular}

$\uparrow$ Intermediate values of $\mathrm{NO}_{2}{ }^{-}$concentration were measured after $75 \%$ of the SRAT reflux had elapsed (these samples were not caustic quenched, and are presumed to be lower bounds on nitrite)

$\ddagger$ During the ARP-MCU run, the intermediate value of $\mathrm{NO}_{2}$ concentration was measured after about $75 \%$ of the total SRAT post-dewater interval (i.e., MCU boiling + SRAT reflux) had elapsed or about half-way during the reflux process.

Table 27 Flowsheet SRAT Anion Reactions

\begin{tabular}{|l|c|c|c|c|c|}
\hline & $\begin{array}{c}\text { SB7-5 } \\
\text { Low Acid }\end{array}$ & $\begin{array}{c}\text { SB7-6 } \\
\text { High Acid }\end{array}$ & $\begin{array}{c}\text { SB7-7 } \\
\text { ARP-SRAT } \\
\text { Products }\end{array}$ & $\begin{array}{c}\text { SB7-8 } \\
\text { Extended }\end{array}$ & $\begin{array}{c}\text { SB7-9 } \\
\text { Baseline } \\
\text { Acid }\end{array}$ \\
\hline Nitrite Los5\% & 100 & 100 & 100 & 100 & 100 \\
\hline Net Nitrite-to-Nitrate \% & 7.4 & 2.2 & 1.0 & 14.5 & 16.9 \\
\hline Formate Loss\% & 22.1 & 35.4 & 22.8 & 29.8 & 25.5 \\
\hline Formate Lost, g & 31.6 & 76.0 & 34.9 & 47.6 & 40.2 \\
\hline
\end{tabular}


Table 28 Calcined Elemental Composition, wt \%, of Flowsheet SRAT Products $\left(1100^{\circ} \mathrm{C}\right)$

\begin{tabular}{|c|c|c|c|c|c|}
\hline Element & $\begin{array}{c}\text { SB7-5 } \\
\text { Low Acid }\end{array}$ & $\begin{array}{c}\text { SB7-6 } \\
\text { High Acid }\end{array}$ & $\begin{array}{c}\text { SB7-7 } \\
\text { ARP-SRAT } \\
\text { Products }\end{array}$ & $\begin{array}{c}\text { SB7-8 } \\
\text { Extended }\end{array}$ & $\begin{array}{c}\text { SB7-9 } \\
\text { Baseline } \\
\text { Acid }\end{array}$ \\
\hline $\mathrm{Al}$ & 15.7 & 15.5 & 13.8 & 15.5 & 15.4 \\
\hline $\mathrm{Ba}$ & 0.109 & 0.111 & 0.112 & 0.119 & 0.117 \\
\hline $\mathrm{Ca}$ & 0.845 & 0.845 & 0.873 & 0.794 & 0.794 \\
\hline $\mathrm{Ce}$ & 0.162 & 0.168 & 0.147 & 0.184 & 0.184 \\
\hline $\mathrm{Cr}$ & 0.070 & 0.070 & 0.075 & 0.080 & 0.078 \\
\hline $\mathrm{Cu}$ & 0.074 & 0.082 & 0.072 & 0.039 & 0.046 \\
\hline $\mathrm{Fe}$ & 20.3 & 20.0 & 17.8 & 19.6 & 19.7 \\
\hline $\mathrm{K}$ & 0.113 & 0.126 & 0.117 & 0.119 & 0.113 \\
\hline $\mathrm{La}$ & 0.081 & 0.081 & 0.072 & 0.089 & 0.089 \\
\hline $\mathrm{Li}$ & $<0.1$ & $<0.1$ & $<0.1$ & $<0.1$ & $<0.1$ \\
\hline $\mathrm{Mg}$ & 0.408 & 0.409 & 0.490 & 0.453 & 0.444 \\
\hline $\mathrm{Mn}$ & 4.97 & 4.89 & 4.45 & 5.05 & 5.00 \\
\hline $\mathrm{Na}$ & 14.3 & 14.6 & 16.7 & 14.7 & 15.0 \\
\hline $\mathrm{Ni}$ & 3.39 & 3.28 & 2.77 & 3.27 & 3.30 \\
\hline $\mathrm{Pb}$ & 0.023 & 0.025 & 0.030 & 0.030 & 0.022 \\
\hline $\mathrm{Rh}$ & $<0.1$ & $<0.1$ & $<0.1$ & $<0.1$ & $<0.1$ \\
\hline $\mathrm{Ru}$ & $<0.1$ & $<0.1$ & $<0.1$ & $<0.1$ & $<0.1$ \\
\hline $\mathrm{S}$ & 0.354 & 0.351 & 0.419 & 0.383 & 0.340 \\
\hline $\mathrm{Si}$ & 1.79 & 1.76 & 1.57 & 1.74 & 1.72 \\
\hline $\mathrm{Ti}$ & 0.027 & 0.030 & 2.96 & 0.030 & 0.030 \\
\hline $\mathrm{Zn}$ & 0.063 & 0.061 & 0.068 & 0.064 & 0.063 \\
\hline $\mathrm{Zr}$ & 0.253 & 0.263 & 0.261 & 0.269 & 0.268 \\
\hline & & & & & \\
\hline
\end{tabular}


Table 29 Elemental Composition of Flowsheet SRAT Product Supernate

\begin{tabular}{|c|c|c|c|c|c|}
\hline Element & $\begin{array}{c}\text { SB7-5 } \\
\text { Low Acid } \\
\mathbf{m g} / \mathbf{L}\end{array}$ & $\begin{array}{c}\text { SB7-6 } \\
\text { High Acid } \\
\mathbf{m g} / \mathbf{L}\end{array}$ & $\begin{array}{c}\text { SB7-7 } \\
\text { ARP-SRAT } \\
\text { Products, } \\
\text { mg/L }\end{array}$ & $\begin{array}{c}\text { SB7-8 } \\
\text { Extended } \\
\text { mg/L }\end{array}$ & $\begin{array}{c}\text { SB7-9 } \\
\text { Baseline } \\
\text { Acid, mg/L }\end{array}$ \\
\hline $\mathrm{Al}$ & 0.946 & 0.867 & 0.949 & 0.435 & 0.382 \\
\hline $\mathrm{B}$ & 1.32 & 1.36 & 1.13 & 0.898 & 0.737 \\
\hline $\mathrm{Ca}$ & 17.2 & 47.1 & 8.71 & 5.87 & 28.2 \\
\hline $\mathrm{Ce}$ & 0.168 & 1.55 & $<0.1$ & 0.45 & $<0.1$ \\
\hline $\mathrm{Cr}$ & $<0.1$ & $<0.1$ & $<0.1$ & $<0.1$ & $<0.1$ \\
\hline $\mathrm{Cu}$ & 0.262 & 0.670 & 0.18 & $<0.1$ & $<0.1$ \\
\hline $\mathrm{Fe}$ & $<1$ & $<1$ & $<1$ & $<1$ & $<1$ \\
\hline $\mathrm{K}$ & 403 & 366 & 743 & 487 & 442 \\
\hline $\mathrm{Li}$ & $<10$ & $<10$ & $<10$ & $<10$ & $<10$ \\
\hline $\mathrm{Mg}$ & 70.1 & 368 & 235 & 21.5 & 166 \\
\hline $\mathrm{Mn}$ & 285 & 3565 & 905 & 70.0 & 1043 \\
\hline $\mathrm{Ni}$ & 0.170 & 6.75 & 7.02 & $<0.1$ & 0.397 \\
\hline $\mathrm{Rh}$ & $<1$ & 1 & $<1$ & $<1$ & $<1$ \\
\hline $\mathrm{Ru}$ & $<1$ & 2 & $<1$ & $<1$ & $<1$ \\
\hline $\mathrm{S}$ & 731 & 684 & 1039 & 639 & 619 \\
\hline $\mathrm{Si}$ & 23.4 & 27.8 & 23.2 & 60.0 & 14.4 \\
\hline $\mathrm{Sn}$ & 0.351 & 3.31 & $\mathrm{~N} / \mathrm{A}$ & $\mathrm{N} / \mathrm{A}$ & $\mathrm{N} / \mathrm{A}$ \\
\hline $\mathrm{Ti}$ & 0.164 & 0.170 & $<0.1$ & $<0.1$ & $<0.1$ \\
\hline $\mathrm{Zn}$ & $<0.1$ & $<0.1$ & $<0.1$ & $<0.1$ & $<0.1$ \\
\hline $\mathrm{Zr}$ & $<0.1$ & $<0.1$ & $<0.1$ & $<0.1$ & $<0.1$ \\
\hline & & & & & \\
\hline
\end{tabular}

The SME elemental data for both the calcined and supernate phases are given below. The waste loading targets for four of the five flowsheet runs, excluding the ARP-MCU, varied were $36.0 \%$ and the actual waste loading values varied from $36.9 \%$ to $37.3 \%$. The ARP-MCU run yielded a waste loading of $34.6 \%$. Despite the slightly lesser value of SB7-7, all five values agree sufficiently well with each other and indicate good control over the waste loading; Frit 418 was used.

Table 30 Properties of Flowsheet SME Products

\begin{tabular}{|l|c|c|c|c|c|}
\hline & $\begin{array}{c}\text { SB7-5 } \\
\text { Low Acid }\end{array}$ & $\begin{array}{c}\text { SB7-6 } \\
\text { High } \\
\text { Acid }\end{array}$ & $\begin{array}{c}\text { SB7-7 } \\
\text { ARP-SME } \\
\text { Products }\end{array}$ & $\begin{array}{c}\text { SB7-8 } \\
\text { Extended }\end{array}$ & $\begin{array}{c}\text { SB7-9 } \\
\text { Baseline }\end{array}$ \\
\hline $\mathrm{Wt} \%$ Total Solids & 47.9 & 47.9 & 52.8 & 48.0 & 47.7 \\
\hline $\mathrm{Wt} \%$ Insoluble Solids & 39.7 & 39.5 & 41.8 & 40.3 & 38.7 \\
\hline $\mathrm{Wt} \%$ Soluble Solids & 8.2 & 8.4 & 11.1 & 7.7 & 9.0 \\
\hline $\mathrm{Wt} \%$ Calcined & 41.2 & 40.7 & 45.1 & 41.7 & 40.9 \\
\hline Slurry density, g/mL & 1.32 & 1.40 & 1.47 & 1.40 & 1.38 \\
\hline Supernate density, g/mL & 1.09 & 1.10 & 1.12 & 1.09 & 1.09 \\
\hline $\mathrm{pH}$ at $25^{\circ} \mathrm{C}$ & 8.1 & 7.4 & 7.4 & 8.2 & 7.6 \\
\hline $\mathrm{Wt} \% \mathrm{Hg}$, total solids & 0.109 & 0.010 & -- & 0.028 & 0.021 \\
\hline
\end{tabular}


Table 31 Flowsheet SME Product Anions

\begin{tabular}{|l|c|c|c|c|c|}
\hline & $\begin{array}{c}\text { SB7-5 } \\
\text { Low Acid }\end{array}$ & $\begin{array}{c}\text { SB7-6 } \\
\text { High } \\
\text { Acid }\end{array}$ & $\begin{array}{c}\text { SB7-7 } \\
\text { ARP-SME } \\
\text { Products }\end{array}$ & $\begin{array}{c}\text { SB7-8 } \\
\text { Extended }\end{array}$ & $\begin{array}{c}\text { SB7-9 } \\
\text { Baseline } \\
\text { Acid }\end{array}$ \\
\hline Nitrite, $\mathrm{mg} / \mathrm{kg}$ & $<100$ & $<100$ & $<100$ & $<100$ & $<100$ \\
\hline Nitrate, $\mathrm{mg} / \mathrm{kg}$ & 19,550 & 21,050 & 21,500 & 18,400 & 19,600 \\
\hline Formate, $\mathrm{mg} / \mathrm{kg}$ & 35,400 & 39,350 & 43,800 & 33,250 & 35,450 \\
\hline Sulfate, $\mathrm{mg} / \mathrm{kg}$ & 1,020 & 1,130 & 2,205 & 1,100 & 1,065 \\
\hline Chloride, $\mathrm{mg} / \mathrm{kg}$ & 235 & 225 & 466 & 282 & 271 \\
\hline
\end{tabular}

Table 32 Calcined Elemental Composition, wt $\%$, of Flowsheet SME Products $\left(1100^{\circ} \mathrm{C}\right)$

\begin{tabular}{|c|c|c|c|c|c|}
\hline Element & $\begin{array}{c}\text { SB7-5 } \\
\text { Low Acid }\end{array}$ & $\begin{array}{c}\text { SB7-6 } \\
\text { High Acid }\end{array}$ & $\begin{array}{c}\text { SB7-7 } \\
\text { ARP-SME } \\
\text { Products }\end{array}$ & $\begin{array}{c}\text { SB7-8 } \\
\text { Extended }\end{array}$ & $\begin{array}{c}\text { SB7-9 } \\
\text { Baseline }\end{array}$ \\
\hline $\mathrm{Al}$ & 5.92 & 5.93 & 5.36 & 6.11 & 5.93 \\
\hline $\mathrm{B}$ & 1.42 & 1.38 & 1.42 & 1.42 & 1.43 \\
\hline $\mathrm{Ba}$ & 0.039 & 0.042 & 0.042 & 0.041 & 0.042 \\
\hline $\mathrm{Ca}$ & 0.351 & 0.366 & 0.372 & 0.377 & 0.353 \\
\hline $\mathrm{Ce}$ & 0.060 & 0.059 & 0.051 & 0.061 & 0.062 \\
\hline $\mathrm{Cr}$ & 0.037 & 0.044 & 0.031 & 0.028 & 0.046 \\
\hline $\mathrm{Cu}$ & 0.027 & 0.020 & 0.038 & 0.025 & 0.034 \\
\hline $\mathrm{Fe}$ & 7.39 & 7.27 & 6.74 & 7.31 & 7.07 \\
\hline $\mathrm{K}$ & 0.074 & 0.089 & 0.119 & 0.090 & 0.086 \\
\hline $\mathrm{La}$ & 0.027 & 0.030 & 0.025 & 0.029 & 0.030 \\
\hline $\mathrm{Li}$ & 2.21 & 2.22 & 2.18 & $<0.1$ & 2.22 \\
\hline $\mathrm{Mg}$ & 0.162 & 0.163 & 0.196 & 0.171 & 0.172 \\
\hline $\mathrm{Mn}$ & 1.81 & 1.76 & 1.61 & 1.81 & 1.73 \\
\hline $\mathrm{Na}$ & 9.28 & 9.22 & 9.91 & 9.73 & 9.58 \\
\hline $\mathrm{Ni}$ & 1.18 & 1.17 & 1.03 & 1.20 & 1.17 \\
\hline $\mathrm{Pb}$ & 0.013 & 0.012 & 0.012 & 0.012 & 0.012 \\
\hline $\mathrm{Rh}$ & $<0.1$ & $<0.1$ & $<0.1$ & $<0.1$ & $<0.1$ \\
\hline $\mathrm{Ru}$ & $<0.1$ & $<0.1$ & $<0.1$ & $<0.1$ & $<0.1$ \\
\hline $\mathrm{S}$ & 0.106 & 0.119 & 0.138 & 0.110 & 0.103 \\
\hline $\mathrm{Si}$ & 23.9 & 23.9 & 22.2 & 23.4 & 22.5 \\
\hline $\mathrm{Ti}$ & 0.052 & 0.055 & 1.15 & 0.058 & 0.056 \\
\hline $\mathrm{Zn}$ & 0.021 & 0.035 & 0.025 & 0.023 & 0.024 \\
\hline $\mathrm{Zr}$ & 0.173 & 0.190 & 0.182 & 0.186 & 0.189 \\
\hline
\end{tabular}


Table 33 Elemental Composition of Flowsheet SME Product Supernates

\begin{tabular}{|c|c|c|c|c|c|}
\hline Element & $\begin{array}{c}\text { SB7-5 } \\
\text { Low Acid } \\
\text { mg/L }\end{array}$ & $\begin{array}{c}\text { SB7-6 } \\
\text { High Acid } \\
\mathbf{m g} / \mathbf{L}\end{array}$ & $\begin{array}{c}\text { SB7-7 } \\
\text { ARP-SRAT } \\
\text { Products, } \\
\mathbf{m g} / \mathbf{L}\end{array}$ & $\begin{array}{c}\text { SB7-8 } \\
\text { Extended } \\
\mathbf{m g} / \mathbf{L}\end{array}$ & $\begin{array}{c}\text { SB7-9 } \\
\text { Baseline } \\
\text { Acid, mg/L }\end{array}$ \\
\hline $\mathrm{Al}$ & 1.02 & 1.04 & 0.934 & 0.351 & 0.340 \\
\hline $\mathrm{B}$ & 6.38 & 24.3 & 36.3 & 6.20 & 10.8 \\
\hline $\mathrm{Ca}$ & 42.0 & 71.9 & 32.7 & 29.6 & 49.1 \\
\hline $\mathrm{Ce}$ & 0.731 & 2.64 & 0.446 & $<0.1$ & $<0.1$ \\
\hline $\mathrm{Cr}$ & $<0.1$ & $<0.1$ & $<0.1$ & $<0.1$ & $<0.1$ \\
\hline $\mathrm{Cu}$ & 0.556 & 0.793 & 0.222 & 0.225 & 0.168 \\
\hline $\mathrm{Fe}$ & $<1$ & $<1$ & 18.2 & $<1$ & $<1$ \\
\hline $\mathrm{K}$ & 507 & 482 & 1118 & 633 & 585 \\
\hline $\mathrm{Li}$ & 223 & 228 & $<10$ & $<10$ & $<10$ \\
\hline $\mathrm{Mg}$ & 178 & 506 & 469 & 89.8 & 299 \\
\hline $\mathrm{Mn}$ & 1457 & 5827 & 3306 & 413 & 2757 \\
\hline $\mathrm{Ni}$ & 1.48 & 19.0 & 37.7 & 0.243 & 4.23 \\
\hline $\mathrm{Rh}$ & $<1$ & 1 & $<1$ & $<1$ & $<1$ \\
\hline $\mathrm{Ru}$ & $<1$ & 5 & $<1$ & $<1$ & $<1$ \\
\hline $\mathrm{S}$ & 961 & 942 & 1527 & 880 & 859 \\
\hline $\mathrm{Si}$ & 15.5 & 41.9 & 33.4 & 24.4 & 15.3 \\
\hline $\mathrm{Sn}$ & 1.57 & 5.73 & $\mathrm{~N} / \mathrm{A}$ & $\mathrm{N} / \mathrm{A}$ & $\mathrm{N} / \mathrm{A}$ \\
\hline $\mathrm{Ti}$ & 0.186 & 0.167 & $<0.1$ & $<0.1$ & $<0.1$ \\
\hline $\mathrm{Zn}$ & $<0.1$ & $<0.1$ & $<0.1$ & $<0.1$ & $<0.1$ \\
\hline $\mathrm{Zr}$ & $<0.1$ & $<0.1$ & $<0.1$ & $<0.1$ & $<0.1$ \\
\hline & & & & & \\
\hline
\end{tabular}

\subsubsection{Flowsheet GC Results}

Similar to the qualification data, the flowsheet runs did not exceed the hydrogen peak generation rate design basis limit, 0.65 and $0.223 \mathrm{lb} / \mathrm{hr}$ for the SRAT and SME cycles, respectively. Table 34 shows the peak gas generation rates as measured by the GC during the SRAT cycles. More detailed GC time profile data are shown in Figures 8,9, and 10. Since these figures are congested and do not show the SME data as clearly, SME-only data are given in the Appendix; see Figures 19-21. Hydrogen production was highest for the highest acid run, as expected. The next highest producers of hydrogen were the baseline and extended runs, both at $110 \%$ acid level. The ARPMCU SB7-7 run exhibited reduced hydrogen production, perhaps due to additional oxalate consumption of acid. This is similar to the behavior exhibited by the high oxalate run, SB7-4.

Table 34 Maximum SRAT Gas Generation Rates

\begin{tabular}{|l|c|c|c|c|c|}
\hline \multicolumn{1}{|c|}{ Gas } & $\begin{array}{c}\text { SB7-5 } \\
\text { Low Acid }\end{array}$ & $\begin{array}{c}\text { SB7-6 } \\
\text { High Acid }\end{array}$ & $\begin{array}{c}\text { SB7-7 } \\
\text { ARP-SME Products }\end{array}$ & $\begin{array}{c}\text { SB7-8 } \\
\text { Extended }\end{array}$ & $\begin{array}{c}\text { SB7-9 } \\
\text { Baseline }\end{array}$ \\
\hline $\mathrm{H}_{2}, \mathrm{lb} / \mathrm{hr}$ & 0.005 & 0.31 & 0.02 & 0.06 & 0.06 \\
\hline $\mathrm{N}_{2} \mathrm{O}, \mathrm{lb} / \mathrm{hr}$ & 15.4 & 30.2 & 13.8 & 15.5 & 27.6 \\
\hline $\mathrm{CO}_{2}, \mathrm{lb} / \mathrm{hr}$ & 540 & 629 & 571 & 305 & 699 \\
\hline
\end{tabular}




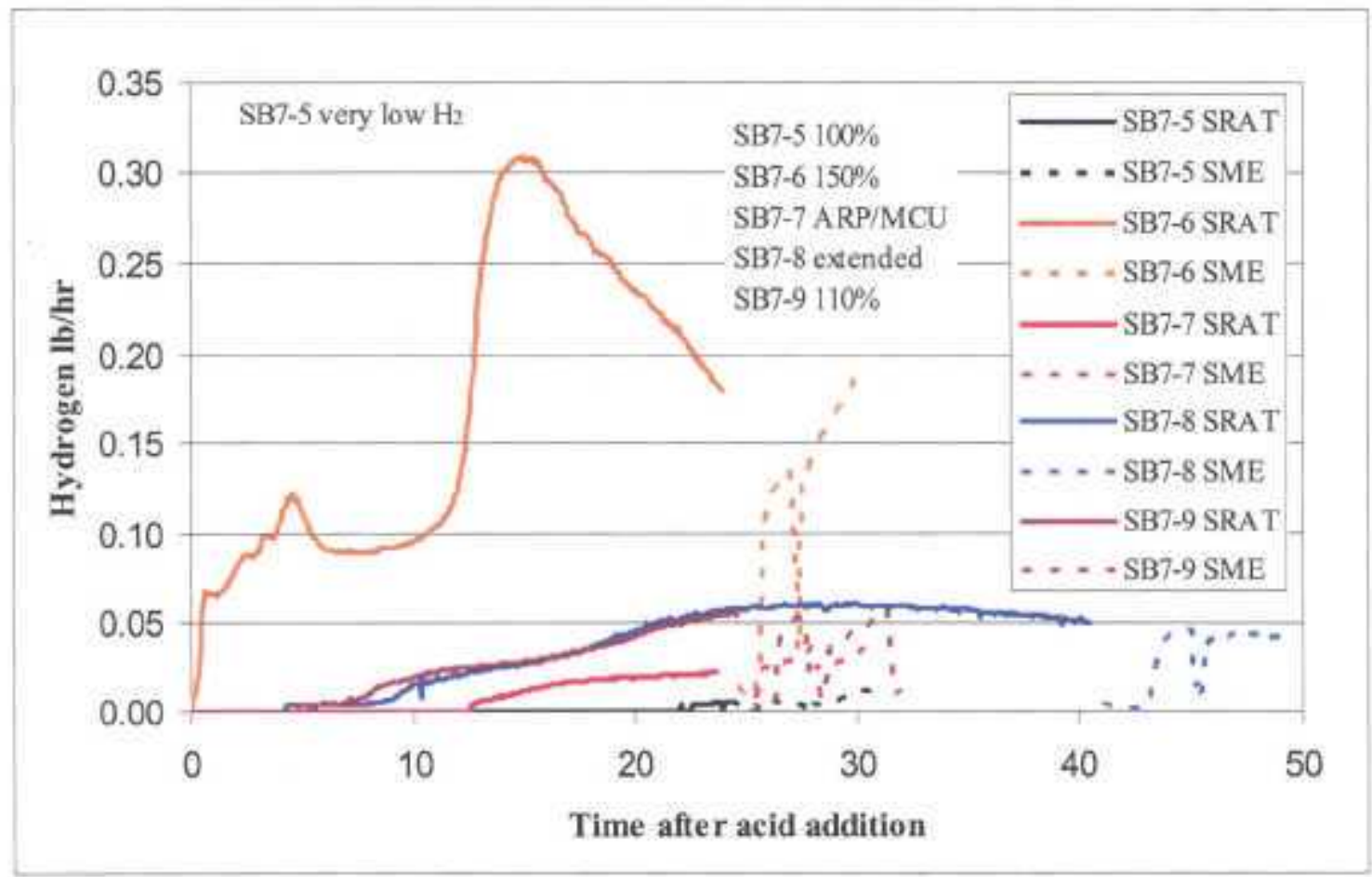

Figure 8 Flowsheet SRAT/SME Hydrogen Profiles

Both $\mathrm{CO}_{2}$ and $\mathrm{N}_{2} \mathrm{O}$ production are greater in the high acid run, Figure 9 and Figure 10, following acid addition. The secondary humps between about 12 and 17 hours after the end of acid addition coincide for all three gases. 


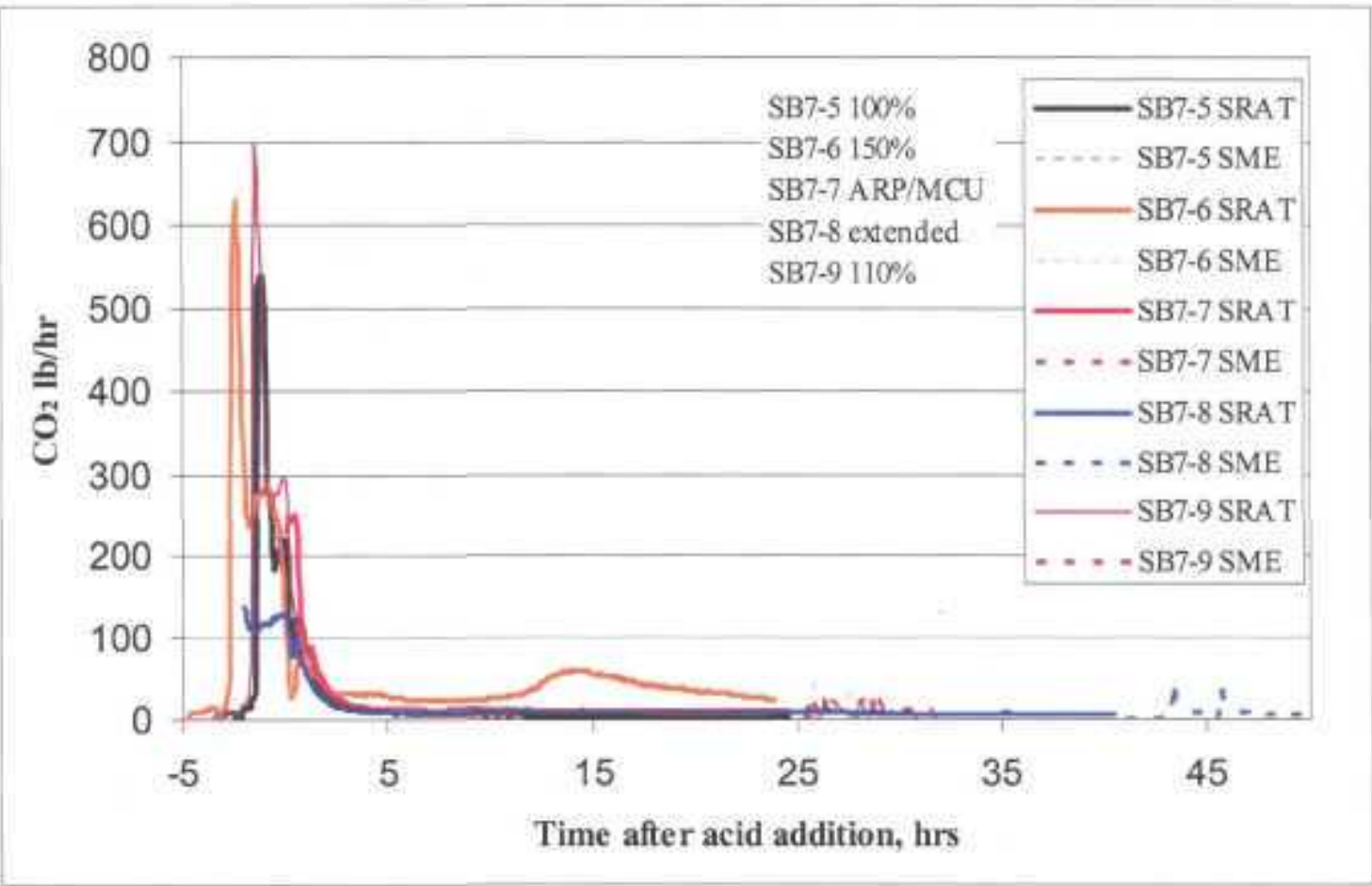

Figure 9 Flowsheet SRAT/SME $\mathrm{CO}_{2}$ Profiles

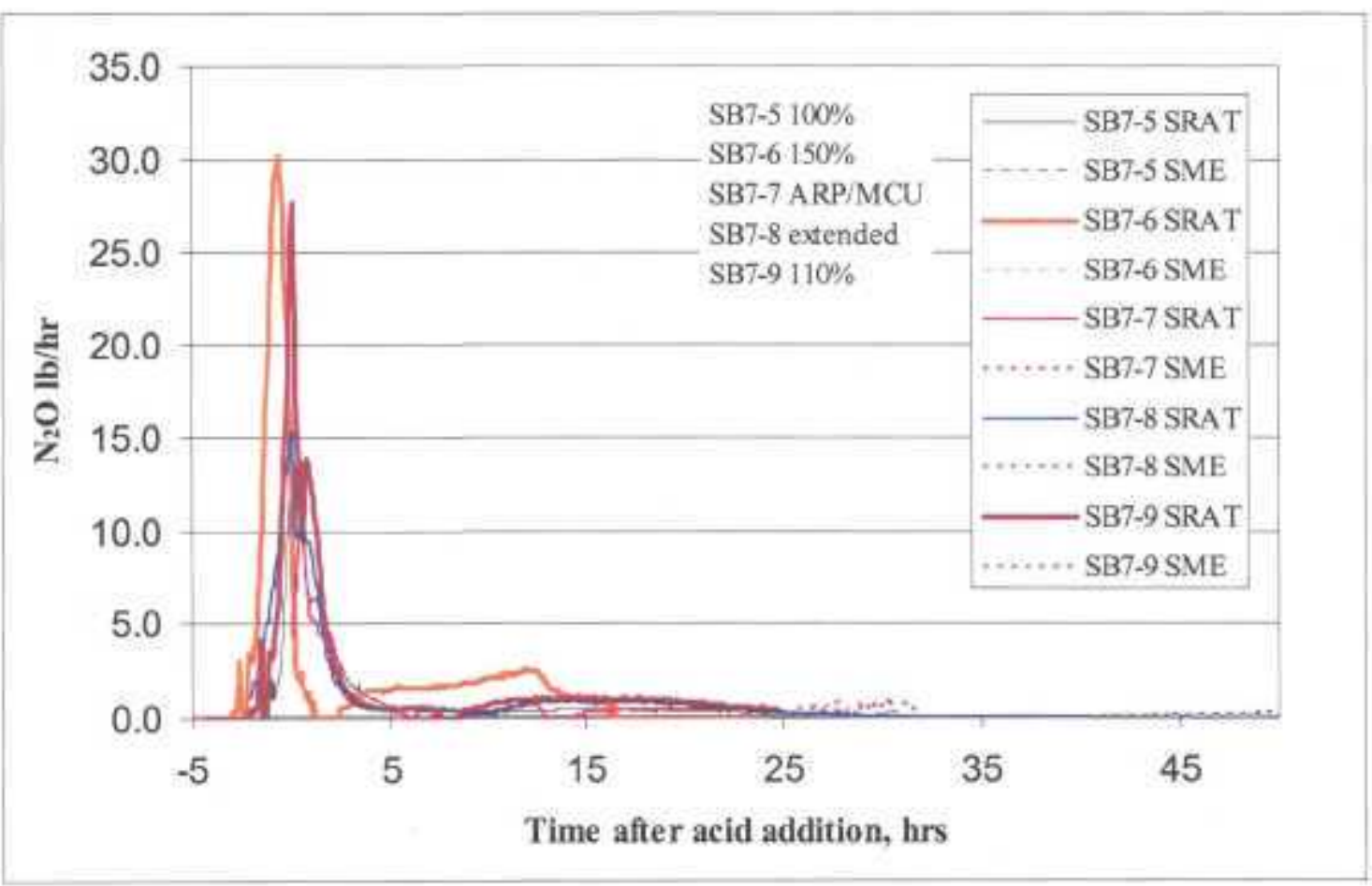

Figure 10 Flowsheet SRAT/SME $\mathrm{N}_{2} \mathrm{O}$ Profiles 


\subsubsection{Flowsheet Ammonia/Ammonium Results}

The concentrations of the ammonia in the ammonia scrubber liquid and of ammonia gas at the outlet of the SRAT condenser are shown in Figure 11. The low acid and ARP-MCU runs did not exhibit production of ammonia or ammonium; this behavior is similar to the behavior of the qualification low acid and high oxalate runs. By contrast, the flowsheet high acid, extended and baseline runs did exhibit ammonia and ammonium generation; again, the high acid and baseline qualification runs also demonstrated the generation of these species. Moreover, the onset of ammonia and ammonium generation of SB7 is similar to that of the previous SB6 study ${ }^{17}$ : as the $\mathrm{pH}$ levels rise above neutral, ammonium and ammonia are produced; see the $\mathrm{pH}$ time profiles in the Appendix, Figure 15.

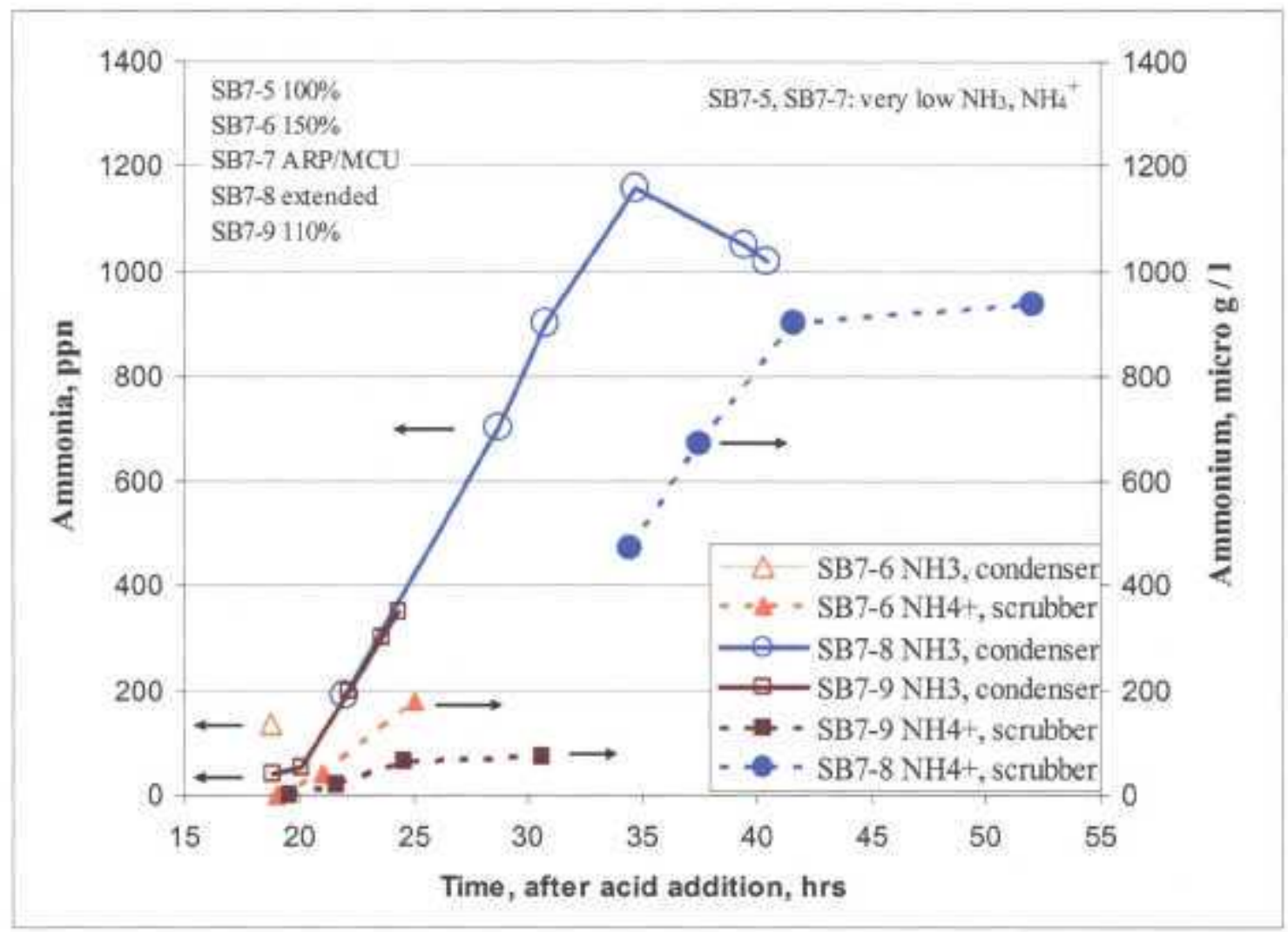

Figure 11 Flowsheet SRAT Ammonia and Ammonium Concentrations

\subsubsection{Flowsheet Mercury Results}

The concentration of mercury was measured in the SRAT/SME kettle and in the gas phase at the outlet of the SRAT condenser; the MWWT was also used to collect $\mathrm{Hg}$. Mercury concentrations in the SRAT and SME product slurries are tabulated; see Table 35 . There are no values listed for SB7-7 ARP-MCU mercury concentrations because the measured values are several times greater than possible, given the initial amount of mercury that was added to the vessel; see Figure 12 and the following discussion. 
Table 35 Mercury Composition in Flowsheet SRAT/SME Product Slurries

\begin{tabular}{|l|c|c|c|c|c|}
\hline & $\begin{array}{c}\text { SB7-5 } \\
\text { Low Acid }\end{array}$ & $\begin{array}{c}\text { SB7-6 } \\
\text { High Acid }\end{array}$ & $\begin{array}{c}\text { SB7-7 } \\
\text { ARP-SME } \\
\text { Products }\end{array}$ & $\begin{array}{c}\text { SB7-8 } \\
\text { Extended }\end{array}$ & $\begin{array}{c}\text { SB7-9 } \\
\text { Baseline }\end{array}$ \\
\hline SRAT, Wt\% Hg, dried solids & 0.042 & 0.021 & -- & 0.123 & 0.040 \\
\hline SME, Wt\% Hg, dried solids & 0.109 & 0.010 & -- & 0.028 & 0.021 \\
\hline
\end{tabular}

Figure 12 shows the $\mathrm{Hg}$ time profile of all five flowsheet slurries. Note that the first values at the end of acid addition refer to a slurry before dewatering and thus are dilute relative to the rest of the data which correspond to sampling during SRAT reflux, i.e., after dewatering was completed. As mentioned above, the high acid run, SB7-6, shows a sudden drop in mercury concentration, consistent with SB6 behavior. ${ }^{1 ?}$

There is an anomalously low value of mercury concentration in the slurry of SB7-5, the low acid case. The qualification high oxalate run exhibited similar behavior, a value that is also ten times too low. By contrast, the ARP-MCU run exhibits slurry concentrations that are several times too great, greater than the amount of $\mathrm{Hg}$ that was trimmed into the system. The reasons for this are unclear but it is unlikely the result of sampling of agglomerated drops of elemental mercury; a two phase mixture of mercury in the slurry would tend to give very low values not larger ones.

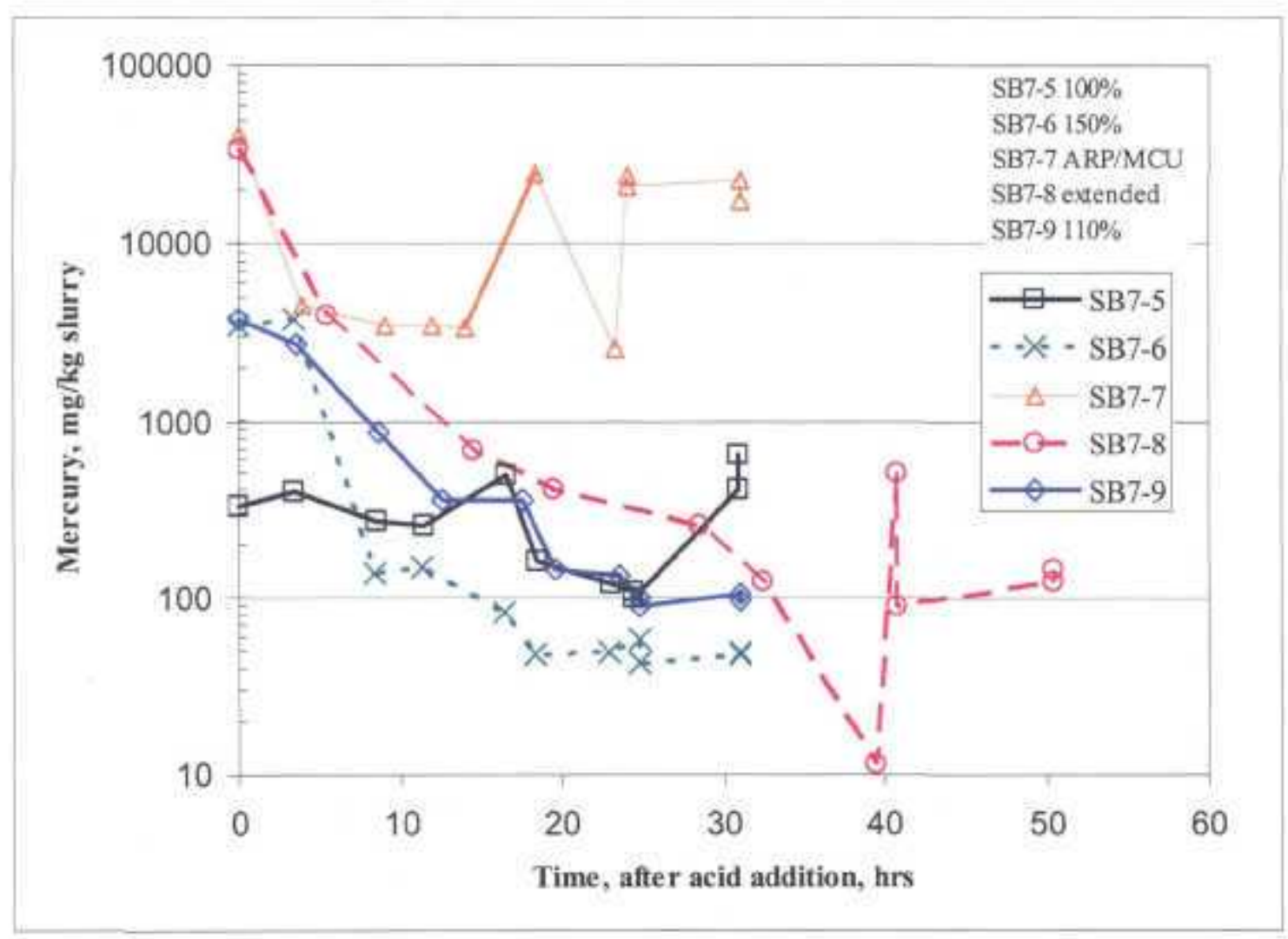

Figure 12 Flowsheet Slurry Mercury Measurements 
Mercury gas measurements are shown in Figure 13. There is nothing unusual to be seen in these sparse data. However, it is obvious that the high acid run causes a greater concentration of mercury in the gas phase. The extended run also exhibits a substantial gaseous concentration of $\mathrm{Hg}$.

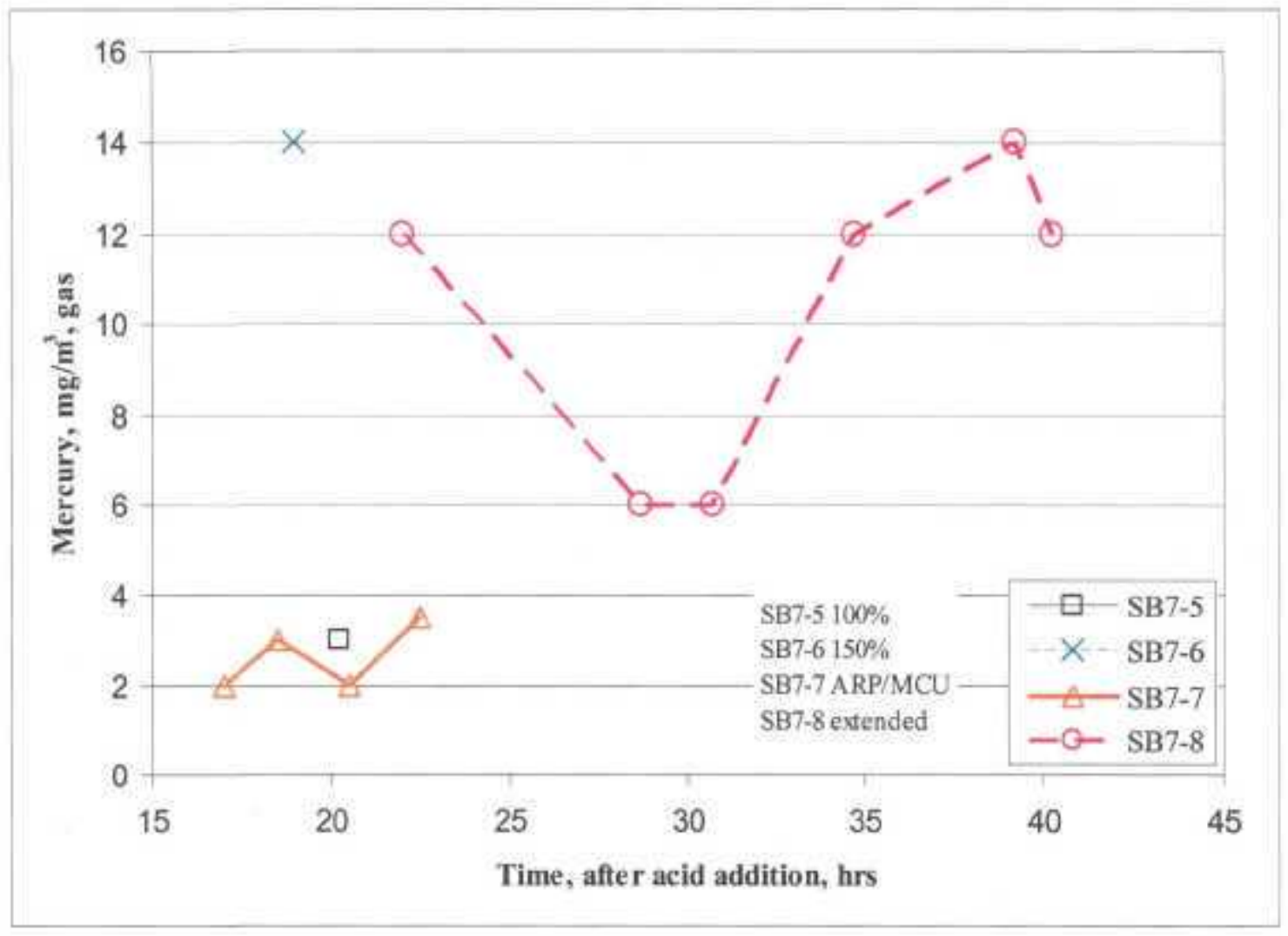

Figure 13 Flowsheet Gaseous Mercury Measurements

In order to understand the fate of mercury in the system, a mass balance is shown in Table 36. The last column indicates that more than half of the mercury is unaccounted for in each of the five runs that has sufficient data. The average $\mathrm{Hg}$ gas concentration is listed and, taking into account the time interval and volumetric flow rate of the total off-gases, a very small mass was lost to off-gassing, several milligrams. The uncertainty of $\mathrm{Hg}$ gas concentration due to somewhat sparse data, Figure 13, is thus irrelevant due to the small mass loss. Nonetheless, these estimated $\mathrm{Hg}$ gas masses are included in the calculation of missing $\mathrm{Hg}$ in Table 36 . There are missing data: a) the aqueous and solid $\mathrm{Hg}$ masses in the SRAT MWWT of SB7-8 and SB7-9 were not measured, the samples were not saved, and thus the data are unavailable and b) the mercury concentration (both replicated measurements) in the SME product of the SB7-7 ARP-MCU run are about an order of magnitude greater than is possible; the values suggest about $54.2 \mathrm{~g}$ which is greater than the total amount of $\mathrm{Hg}$ trimmed in, $14.31 \mathrm{~g}$.

These flowsheet runs, like the qualification runs, exhibit "missing mercury"; greater than half is unaccounted for. It is likely that the missing mercury was present in the apparatus but not sampled. Two possible mechanisms are: a) the matter in the kettle is very heterogeneous and the mercury, present as small, dense agglomerates, was unlikely to be sampled and b) the mercury 
became stuck in a film on the inner walls of the apparatus, primarily the kettle. Based on the data available, loss of mercury by off-gassing is negligible.

Table 36 Flowsheet Mercury Balance

\begin{tabular}{|c|c|c|c|c|c|c|c|c|}
\hline $\begin{array}{c}\text { Run } \\
\text { ID }\end{array}$ & $\begin{array}{c}\text { Hg } \\
\text { input, } \\
\mathbf{g}\end{array}$ & $\begin{array}{c}\text { SRAT } \\
\text { Dewater } \\
\text { recovery, } \\
\text { Hg (aq), }\end{array}$ & $\begin{array}{c}\text { SRAT } \\
\text { MWWT } \\
\text { recovery, } \\
\mathbf{g}+\end{array}$ & $\begin{array}{c}\text { SME } \\
\text { MWWT } \\
\text { recovery, } \\
\mathbf{g}\end{array}$ & $\begin{array}{c}\text { SME } \\
\text { product } \\
\text { recovery, } \mathbf{g}\end{array}$ & $\begin{array}{c}\text { Average } \\
{[\mathbf{H g} \text { gas, }} \\
\mathbf{m g} / \mathbf{m}^{3}\end{array}$ & $\begin{array}{c}\text { Total Hg } \\
\text { recovery, g }\end{array}$ & $\begin{array}{c}\text { Missing } \\
\mathbf{H g} \%\end{array}$ \\
\hline SB7-5 & 14.78 & 0.22 & 4.72 & 0 & 1.23 & 3 & 6.17 & 58 \\
\hline SB7-6 & 14.78 & 0.01 & 2.42 & 0 & 0.12 & 14 & 2.55 & 83 \\
\hline SB7-7 & 14.31 & 0.02 & 4.86 & 0.80 & - & 3 & 5.68 & $>60$ \\
\hline SB7-8 & 14.78 & 0.20 & N/A & N/A & 0.29 & 10 & - & - \\
\hline SB7-9 & 14.78 & 0.20 & N/A & N/A & 0.20 & - & - & - \\
\hline
\end{tabular}

+ The Hg masses listed in the SRAT MWWT are from the solid phase only because the combination of low aqueous concentrations and low overall mass of the liquid make the dissolved $\mathrm{Hg}$ masses very low, less than $10 \mathrm{mg}$; nonetheless, though not listed, these masses have been used in the calculation of the total recovered $\mathrm{Hg}$. The water and mercury from the SRAT MWWT of SB7-8 and SB7-9 were not saved and thus the aqueous and solid Hg mass data are unavailable.

More evidence that the missing mercury for SB7-6 was stuck in the kettle can be obtained by examining the mercury levels in the combined SRAT MWWT dewater condensate, Table 37. The high acid run demonstrates: a) a relatively low level of dissolved Hg in the SRAT MWWT dewater condensate, b) a relatively lower value of undissolved mercury in the MWWT at the end of the SRAT run (Table 36), and c) a very sudden and overwhelming decrease in SRAT slurry mercury (Figure 12) between the end of acid addition and the end of dewatering. If the mercury did not end up in the off-gas system, then it is likely that it remained in the vessel. This phenomenon was observed during the qualification and SB6 work.

Table 37 Mercury Levels in Flowsheet Dewater Condensate

\begin{tabular}{|c|c|}
\hline Run ID & {$\left[\mathbf{H g}_{\operatorname{man}} \mathbf{m g} / \mathbf{L}\right.$ condensate } \\
\hline SB7-5 & 251 \\
\hline SB7-6 & 7.28 \\
\hline SB7-7 & 8.05 \\
\hline SB7-8 & 232 \\
\hline SB7-9 & 229 \\
\hline
\end{tabular}

Moreover, the SRP-MCU run, while exhibiting a comparable recovery in the SRAT MWWT at the end of reflux, yields a low value of aqueous dewater condensate in the MWWT (this is very similar to that of the high acid run). It is unclear why this occurred.

\section{2,5 Flowsheet Rheology}

Rheology measurements were obtained for both the SRAT products, Table 38, and SME products, Table 39. Figures 30 through 39 show the flow curves of the flowsheet SRAT and SME products. Because of time-dependence of some up curves, the down curves were utilized to determine 
Theological properties. As expected the high acid flowsheet run, SB7-6, shows the smallest yield stress and consistency by the end of the SRAT cycle. The second thinnest SRAT product by yield stress is the baseline run, SB7-9, while the thinnest by consistency is the extended run, SB78. The thickest SRAT products correspond to either the low acid or ARP-MCU run. These runs had the highest insoluble solids wt $\%$.

Table 38 Flowsheet SRAT Product Rheology

\begin{tabular}{|l|c|c|c|c|c|}
\hline & $\begin{array}{c}\text { SB7-5 } \\
\text { Low Acid }\end{array}$ & $\begin{array}{c}\text { SB7-6 } \\
\text { High } \\
\text { Acid }\end{array}$ & $\begin{array}{c}\text { SB7-7 } \\
\text { ARP-SRAT } \\
\text { Products }\end{array}$ & $\begin{array}{c}\text { SB7-8 } \\
\text { Extended }\end{array}$ & $\begin{array}{c}\text { SB7-9 } \\
\text { Baseline }\end{array}$ \\
\hline Yield Stress, Pa, Down & 4.7 & 1.1 & 4.1 & 7.1 & 3.3 \\
\hline Consistency, cP, Down & 16 & 5.5 & 14 & 8.1 & 14 \\
\hline Wt \% insoluble solids & 15.8 & 14.7 & 15.4 & 15.6 & 14.4 \\
\hline
\end{tabular}

Because the slurries were concentrated to different levels of insoluble solids in the SME process, Table 39 , and since the rheology is very sensitive to this value, the trends have changed relative to those of the SRAT products. Here, the smallest yield stress still corresponds to the high acid run but the rest of the data suggest more complex behavior.

Table 39 Flowsheet SME Product Rheology

\begin{tabular}{|l|c|c|c|c|c|}
\hline & $\begin{array}{c}\text { SB7-5 } \\
\text { Low Acid }\end{array}$ & $\begin{array}{c}\text { SB7-6 } \\
\text { High } \\
\text { Acid }\end{array}$ & $\begin{array}{c}\text { SB7-7 } \\
\text { ARP-SME } \\
\text { Products }\end{array}$ & $\begin{array}{c}\text { SB7-8 } \\
\text { Extended }\end{array}$ & $\begin{array}{c}\text { SB7-9 } \\
\text { Baseline }\end{array}$ \\
\hline Yield Stress, Pa, Down & 34.8 & 12.0 & 23.4 & 37.4 & 28.3 \\
\hline Consistency, cP, Down & 52.4 & 23.5 & 49.7 & 33.1 & 46.2 \\
\hline Wt \% insoluble solids & 39.7 & 39.5 & 41.8 & 40.3 & 38.7 \\
\hline
\end{tabular}

\subsection{Conclusions}

DWPF Chemical Process Cell (CPC) flowsheet testing was completed with qualification and Flowsheet simulants for Sludge Batch 7. The goals were to determine reasonable operating conditions and detect any possible difficulties or issues regarding the processing of the blend SB6/SB7 (i.e., flowsheet or Tank 40) and the "pure" SB7 (i.e., qualification or Tank 51) sludge. The testing covered the domain from 100 to $150 \%$ of the Koopman minimum acid (KMA) equation or about 102 to $155 \%$ using the current DWPF-Hsu acid equation.

Nitrite ion concentrations were reduced to 760 and $<100 \mathrm{mg} / \mathrm{kg}$ slurry in the qualification and flowsheet $100 \%$ acid (KMA) SRAT products. These data indicate that the Koopman equation accurately models the acid needs of the qualification simulant and those of the flowsheet simulant to a lesser degree. However, even though the flowsheet value could mean an overestimate of the needed acid for nitrite destruction, an intermediate value of nitrite concentration, measured after $75 \%$ of the SRAT reflux had elapsed, yielded a small value of $472 \mathrm{mg} / \mathrm{kg}$. This indicates that while the acid need of the flowsheet simulant was overestimated by KMA, this is a negligible difference. 
The high acid runs produced the highest hydrogen gas generation, but both the flowsheet and qualification cases never exceeded about $85 \%$ of the maximum allowable hydrogen generation rate in the SRAT and SME cycles. The acid processing window for SB7 blended feed is approximately 102 to $155 \%$ Hsu. It is recommended that $110 \%$ KMA or $112 \%$ Hsu be used for SB7 processing.

There were few problems with SB7 simulant processing. A very small amount of foaming was detected around the agitator shafts during SB7-2 (qualification, high acid) and SB7-5 (flowsheet, low acid) but this foaming was not considered problematic. Also there were no instances of ammonia scrubber column flooding. Based on the simulants, the SRAT or SME products, both qualification and flowsheet, should not cause significant issues with mixing or transferring since the rheology was within DWPF limits. The SME product data indicate that all of the runs satisfied the $36 \%$ waste loading target. The performance of an extended run at the prototypical DWPF conditions ( 1 gallon per minute acid addition and $3000 \mathrm{lb} / \mathrm{hr}$ of steam) did not cause any significant problems or changes in gas generation or rheology. Mercury stripping was not satisfactory and the reasons remain unclear. As with SB6, the high acid runs appeared to undergo a very sudden drop of mercury; it is possible that this is due to some complexation of mercury with noble metals in the SRAT vessel.

The addition of simulated Actinide Removal Process (ARP) and Modular Caustic Side Solvent Extraction Unit (MCU) streams to the SRAT cycle did not influence the recommended acid stoichiometry. The increase of oxalate concentration in the qualification study did not cause any processing difficulties but decreases in both hydrogen production and mercury stripping were observed. This observation is relevant as part of the SB7 originates from Tank 7 which, after the enhanced chemical cleaning, contains a high concentration of oxalate.

Initial attempts to quantify oxalate in the SRAT product slurry were suspiciously high using the acid strike method developed during Sludge Batch 3, and subsequent analyses of the nine SME products yielded slurry oxalate values that appeared to be roughly double the amount of oxalate in the starting feed slurry. Further study showed that the acid strike method, when applied to the 5 and $10 \mathrm{ppm}$ oxalate standard solutions, gave results of 16.6 and $19.9 \mathrm{ppm}$. The working hypothesis is that the acid strike matrix is interacting with something internal to the ion chromatograph to produce artificially high oxalate readings. The water dilution oxalate measurements are uncertain, since it is likely that the method does not take into account any undissolved oxalates, such as calcium oxalate. Further method development work is needed so that SME slurry total oxalate can be determined, since it is an input to the current redox model equation and it is present in non-trivial quantities; consequently, the redox predictions were too uncertain to discuss. Once this method is finalized, the samples will be reanalyzed and the report revised with the updated values. Nonetheless, experimental redox measurements of the flowsheet SME products are underway and will be published in a separate report.

There are enduring questions about the fate of mercury. The mercury balance has not been fully closed and as much as $58 \%$ to $86 \%$ of the mercury is unaccounted for. It is likely that the mercury either stuck to the inner surfaces of the apparatus, mostly in the SRAT/SME kettle, or it is possible that the mercury was reduced to the elemental form and remained as part of a heterogeneous, globular component in the SME product; this second possibility would also make sampling difficult because of the small likelihood of capturing a piece of isolated globules of mercury in the slurry, even under agitation. Unlike the Phase III SB6 high acid runs, ${ }^{15}$ there was no visible deposition of mercury or mercury amalgams on the agitator shaft or blades. 
There was a significant amount of ammonium and ammonia generated as the $\mathrm{pH}$ rose above neutral during the SRAT cycles, as was the case for SB6. ${ }^{15,17}$ Secondary peak production of hydrogen, $\mathrm{CO}_{2}$, and $\mathrm{N}_{2} \mathrm{O}$ in the high acid runs of both flowsheet and qualification simulant seem to coincide around the same time, suggesting that a common reactant may be involved in the production of these gases. The production of ammonia and ammonium is likely related to these precursor gases and there is speculation from the SB6 Phase III study that a possible mechanism for producing ammonia would involve a catalyst of either Ru or a mereury amalgam; ${ }^{15}$ there is no evidence here that would either support or discard these possibilities.

\subsection{Recommendations and Path Forward}

It is recommended that DWPF process SB7 at the following acid stoichiometry: $110 \%$ KMA or about $112 \%$ Hsu. If the need should arise, small steps of $5 \%$ increases in acid stoichiometry up to about $155 \%$ Hsu could be used in the search for optimal processing.

Method development is needed to obtain more accurate oxalate concentrations. Once these are resolved, a follow-up to this report (revision 1) will be issued that includes new slurry oxalate values. Moreover, predicted redox values were not included in this report because of the considerable uncertainty in oxalate concentration, which can affect values by \pm 0.05 . Nonetheless, experimental redox measurements of the flowsheet SME products, to be published in a separate report, are underway.

There are unanswered questions regarding the fate of mercury. A follow-up study to this work is being performed and published in a separate report. It involves a detailed analysis of the mercury balance from SRAT/SME cycles, including a detailed examination of the remaining material and apparatus coatings from the flowsheet runs of SB7. Another investigation could involve the characterization of mercury or amalgam species in the SME products from this work; this is similar to the aforementioned Phase III SB6 study which revealed mercury amalgams coating the shaft and agitator blades and free mercury in the SME product sludge. It is possible that these amalgams could be resistant to steam stripping. More information is needed regarding the speciation and fate of the "missing mercury" in SB7. 
SRNL-STI-2011-00006

Revision 0

\subsection{References}

1. Bricker, J.M., Technical Task Request for Sludge Batch 7 Flowsheet Studies, HLWDWPF-TTR-2010-0012, Savannah River Site, Aiken, SC 29808, 2010

2. Fernandez, A.I., Task Technical and Quality Assurance Plan for Sludge Batch 7 Simulant Flowsheet Studies, SRNL-RP-2010-0071, Savannah River National Laboratory, Aiken, SC 29808,2010

3. Ketusky, E.T., Re-investigating the Process Impacts from Oxalic Acid High Level Waste Tank Cleaning, WSRC-STI-2008-00036, Westinghouse Savannah River Company, Aiken, SC 29808, 2008

4. Adu-Wusu, K., et al., Waste Tank Heel Chemical Cleaning Summary, WSRC-TR-200300401, Westinghouse Savannah River Company, Aiken, SC 29808, 2003

5. Davis, N., et al., Enhanced Chemical Cleaning: A New Process for Chemically Cleaning Savannah River Waste Tanks-9100, WSRC-STI-2008-00035, Washington Savannah River Company, Aiken, SC 29808, 2009

6. Poirier, M.R., et al, Removing Sludge Heels from Savannah River Site Waste Tanks by Oxalic Acid Dissolution-9120, SRNL-SETI-2008-00466, Savannah River National Laboratory, Aiken, SC 29808, 2008

7. Stone, M.E., Lab-Scale CPC Equipment Set-Up, SRNL-PSE-2006-00074, Savannah River National Laboratory, Aiken, SC 29808, 2010

8. Koopman, D.C., A Comparison of Rheology Data for Radioactive and Simulant Savannah River Site Waste, WSRC-TR-2004-00044, Savannah River National Laboratory, Aiken, SC 29808, 2004

9. Newell, J.D., Simulant Development for Sludge Batch 6, SRNL-STI-2010-00219, Savannah River National Laboratory, Aiken, SC 29808, 2010

10. Pareizs, I.M. and D.R. Click, Chemical Characterization Results of the SRNL-Washed Tank 5I Sludge Batch 7 Qualification Sample, SRNL-L3100-2010-00252, Savannah River National Laboratory, Aiken, SC 29808, 2010

11. Fellinger, T.L., et al., Macrobatch 3 Acceptrance Evaluation - data from the Shielded Cells Demonstration of Defense Waste Processing Facility's Feed Preparation Cycles for Macrobatch 3 (Sludge Batch 2), WSRC-RP-2001-00971, Washington Savannah River Company, Aiken, SC 29808, 2001

12. Pareizs, J.M., et al., Sludge Batch 3 Qualification in the SRTC Shielded Cells, WSRCTR-2004-00050, Washington Savannah River Technology Company, Aiken, SC 29808. 2004

13. Pareizs, J.M., Demonstration of the DWPF Flowsheet in the SRNL Shielded Cells in Support of Sludge Batch 4 Qualification, WSRC-STI-2007-00053, Savannah River National Laboratory, Aiken, SC 29808, 2007

14. Pareizs, J.M., et al., Sludge Washing and Demonstration of the DWPF Flowsheet in the SRNL Shielded Cells for Sludge Batch 5 Qualification, SRNS-STI-2008-00111, Savannah River National Laboratory, Aiken, SC 29808, 2008

15. Koopman, D.C., Sludge Batch 6/Tank 40 Simulant Chemical Process Cell Simulations, SRNL-STI-2010-00212, Savannah River National Laboratory, Aiken, SC 29808, 2010

16. Koopman, D.C., D.R. Best, and B.R. Pickenheim, SRAT Chemistry and Acid Consumption During Simulated DWPF Melter Feed Preparation, WSRC-STI-200800131, Washington Savannah River Company, Aiken, SC 29808, 2008

17. Fernandez, A.I., Sludge Batch 6 Supplemental SRAT Runs: Effects of Yield Stress and Cycle Time Increase, SRNL-STI-2010-00307, Savannah River National Laboratory, Aiken, SC 29808, 2010 
18. Coleman, C.J., Method to Determine Oxalate in High-Level Shudge by Ion Chromatography, WSRC-TR-2002-00497, Westinghouse Savannah River Company, Aiken, SC 29808, 2002

19. Herman, C.C., et al., Sludge Batch 3 Simulant Flowsheet Studies: Final Phase SRAT/SME Results, WSRC-TR-2003-00422, Westinghouse Savannah River Company, Aiken, SC 29808, 2003 
SRNL-STI-2011-00006

Revision 0

Appendix A 


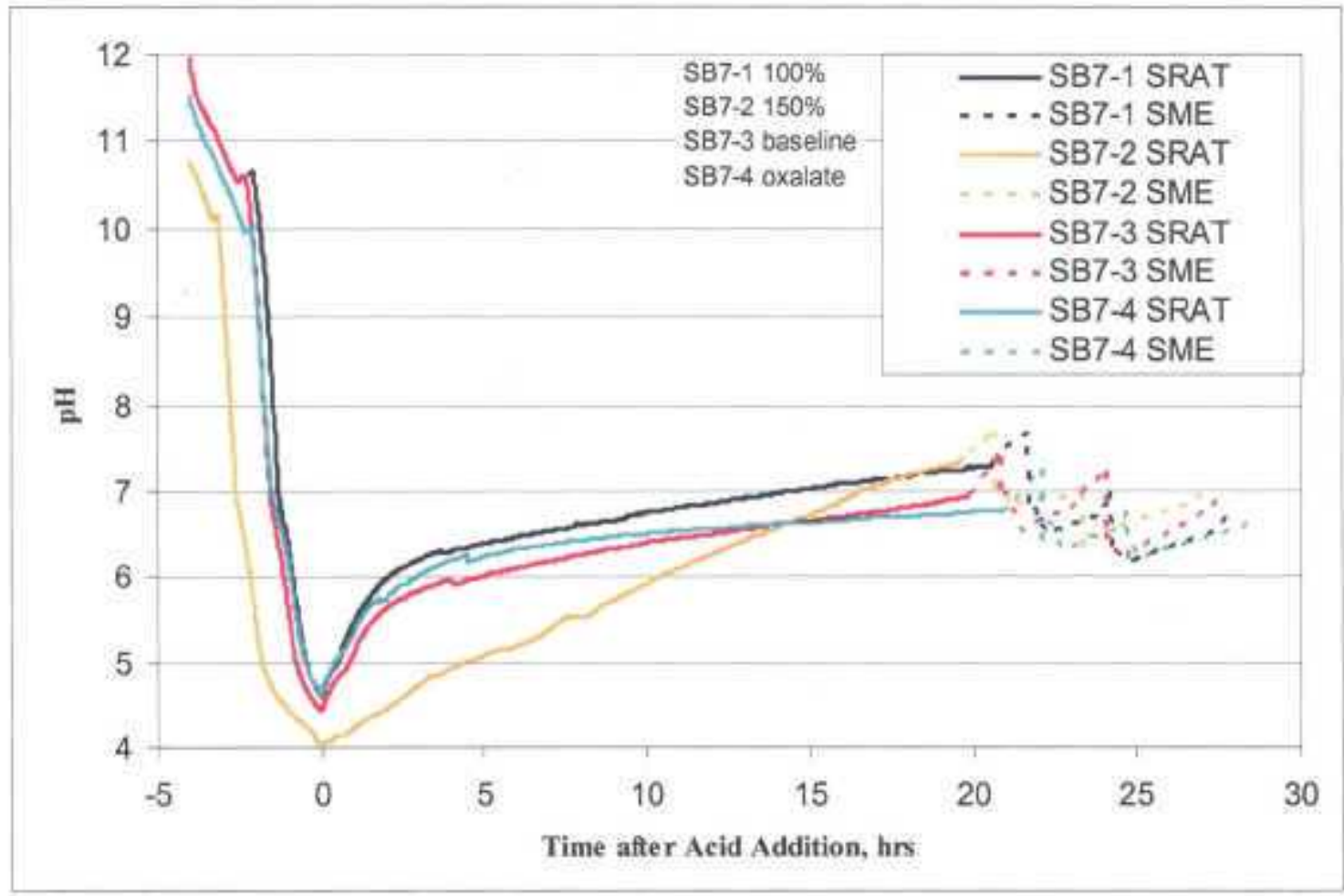

Figure 14 Qualification pH Time Profiles

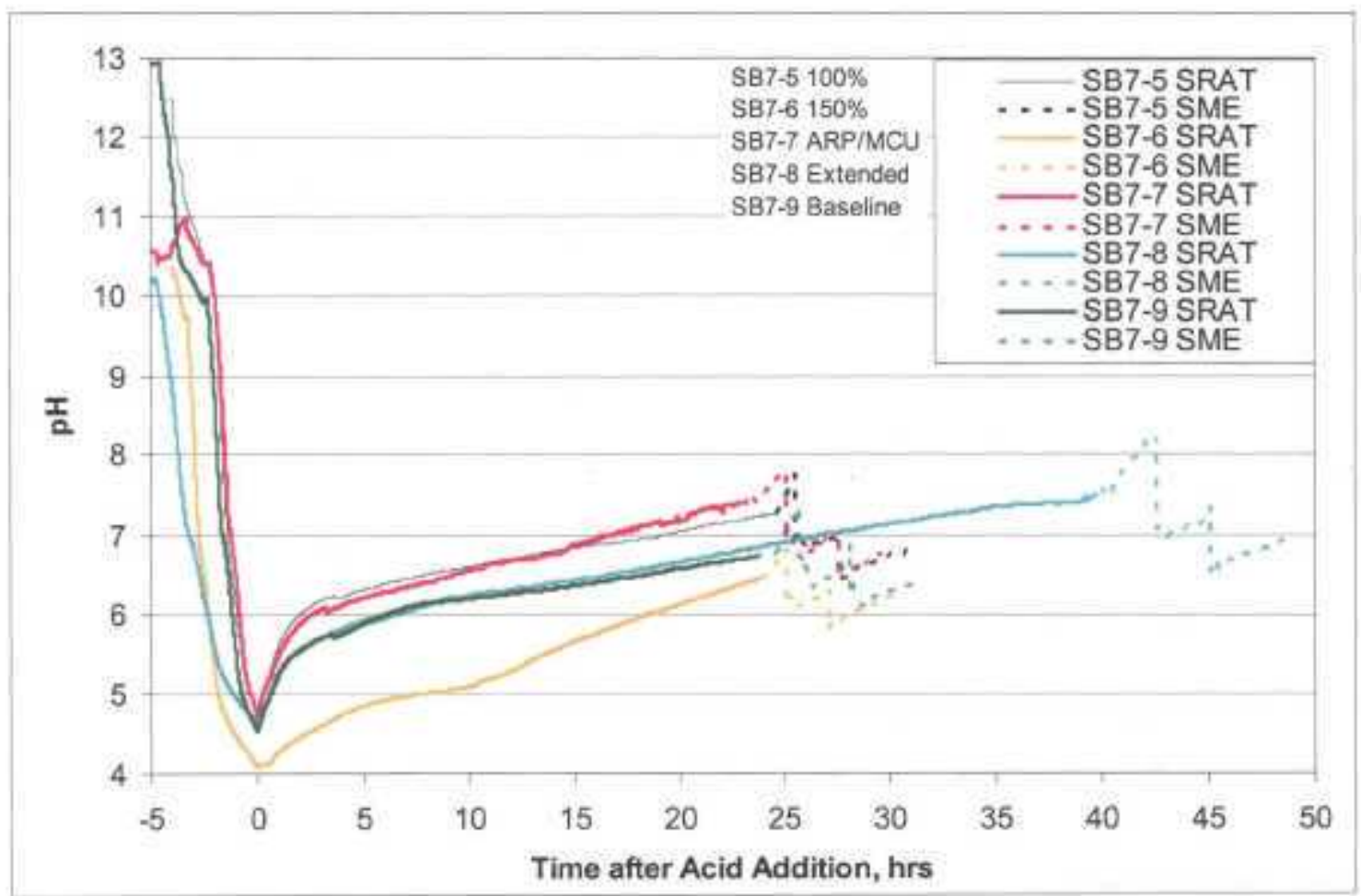

Figure 15 Flowsheet pH Time Profiles 


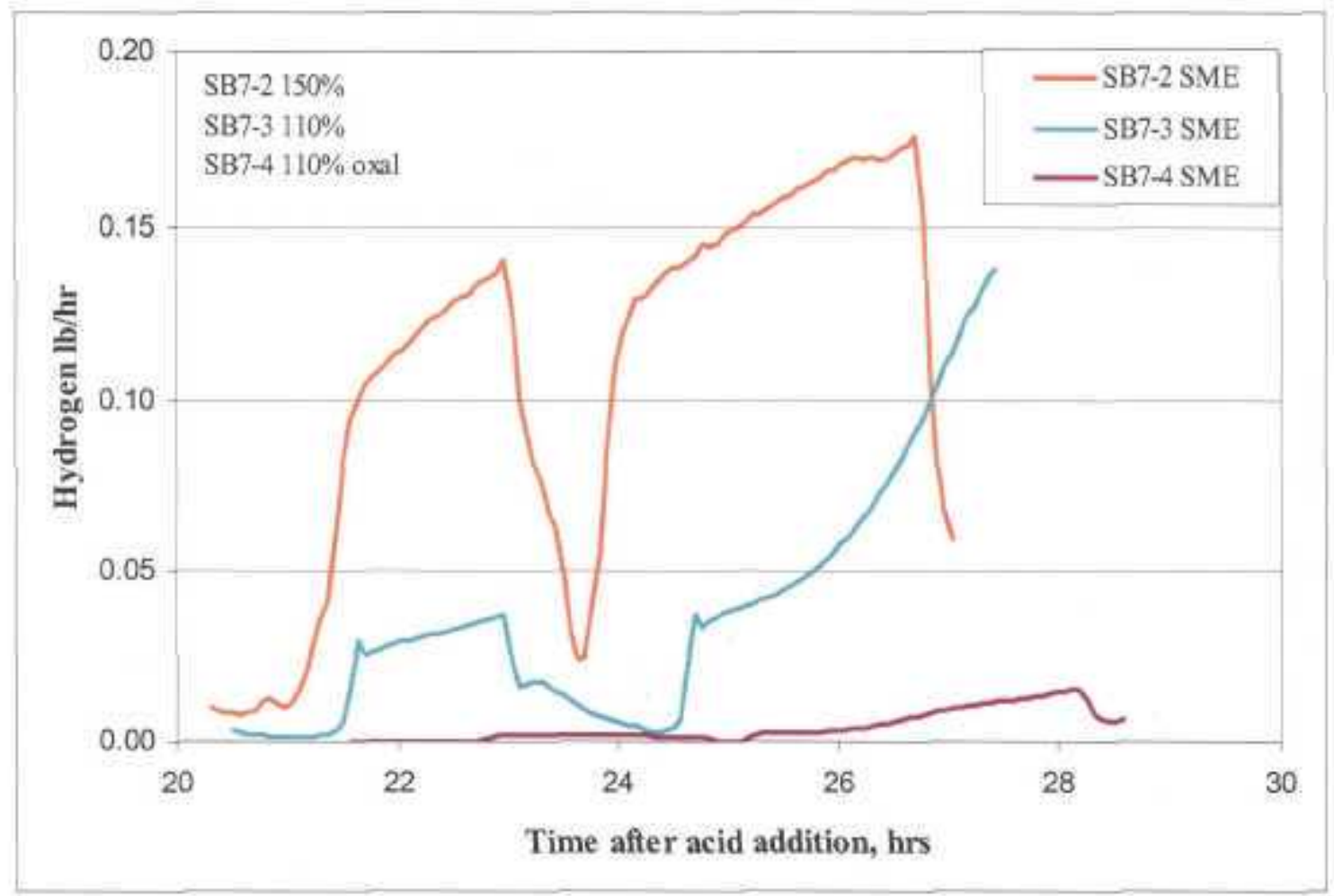

Figure 16 Qualification SME Hydrogen Generation

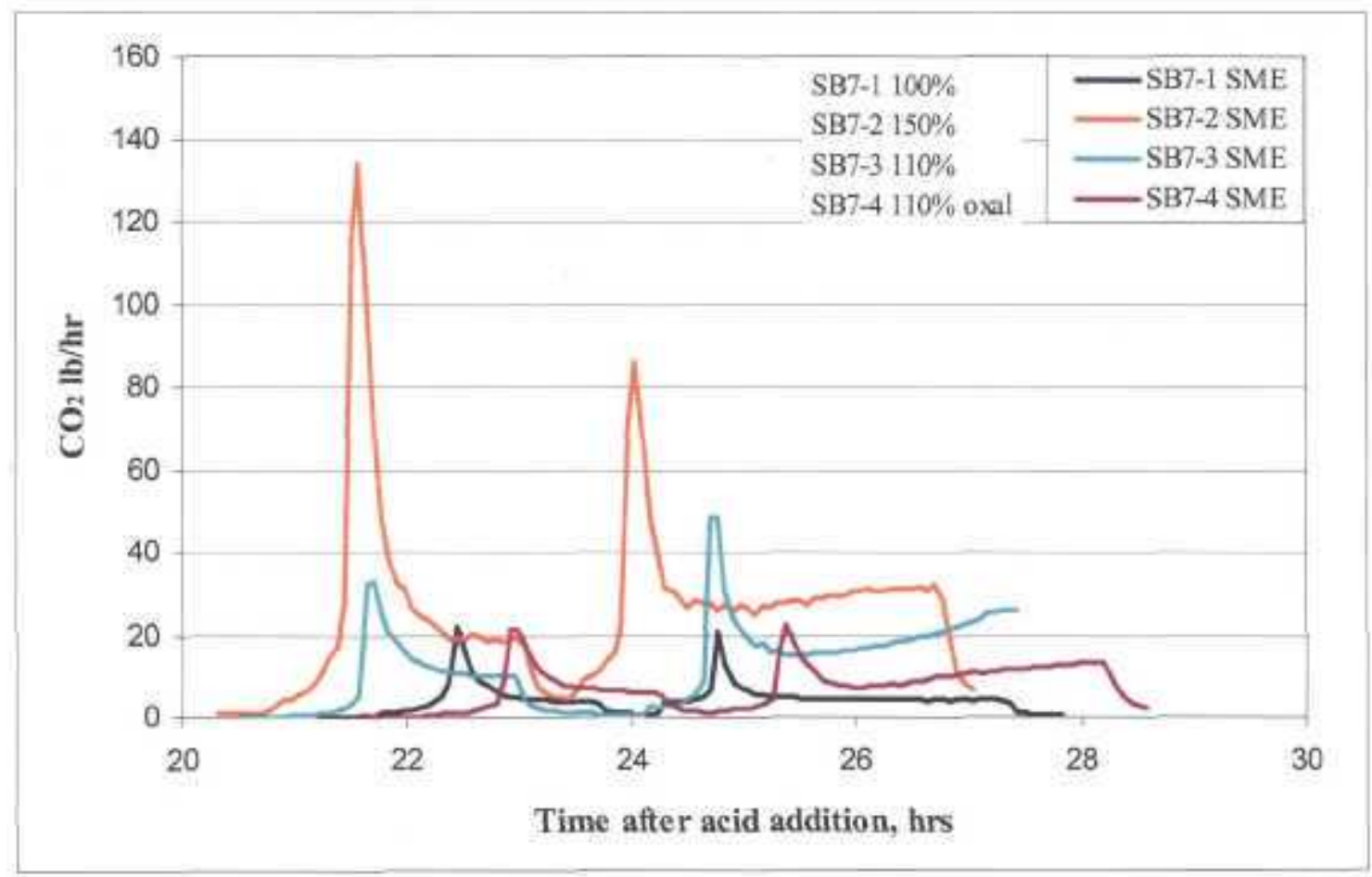

Figure 17 Qualification SME $\mathrm{CO}_{2}$ Generation 


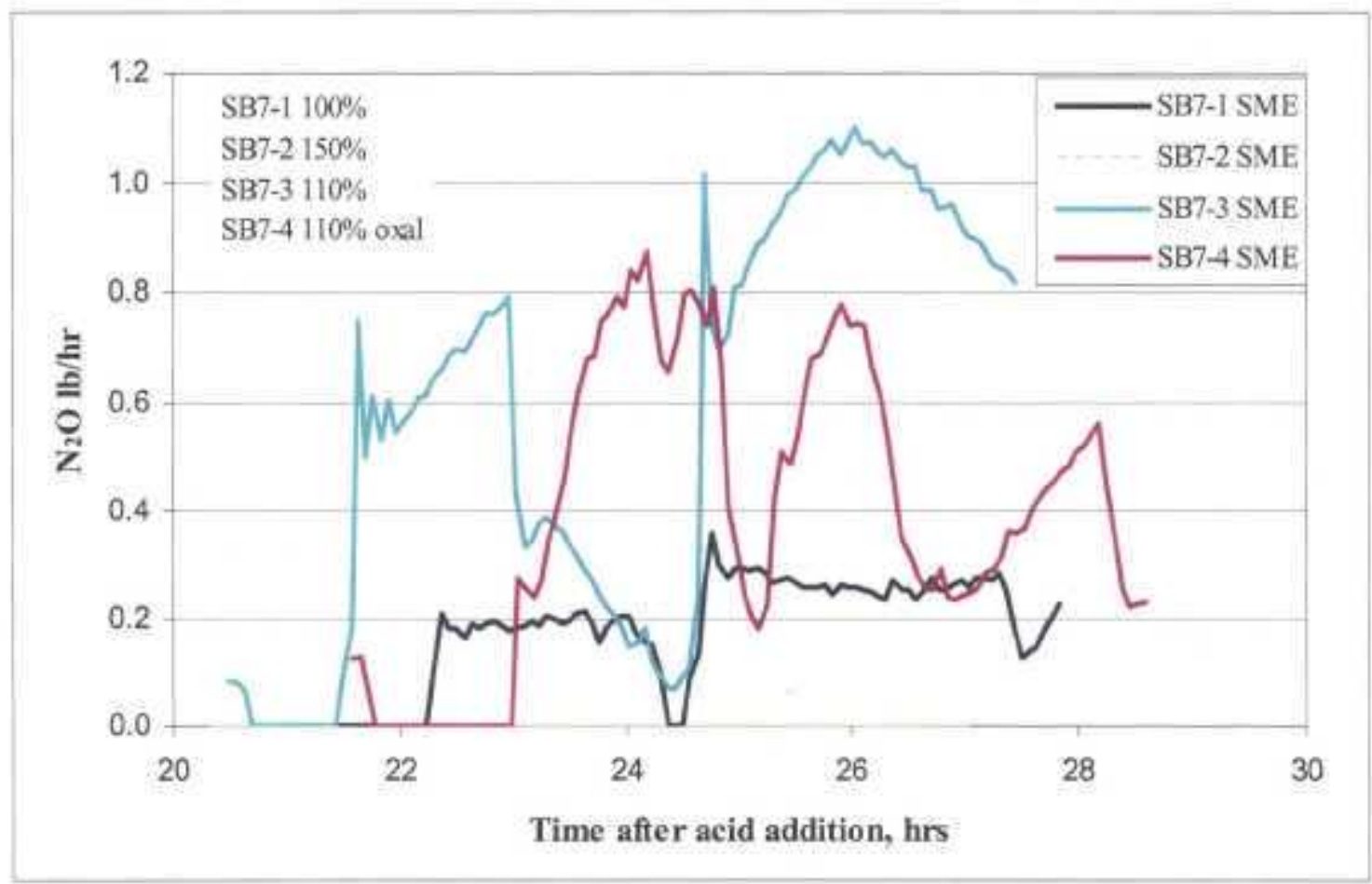

Figure 18 Qualification SME $\mathrm{N}_{2} \mathrm{O}$ Generation

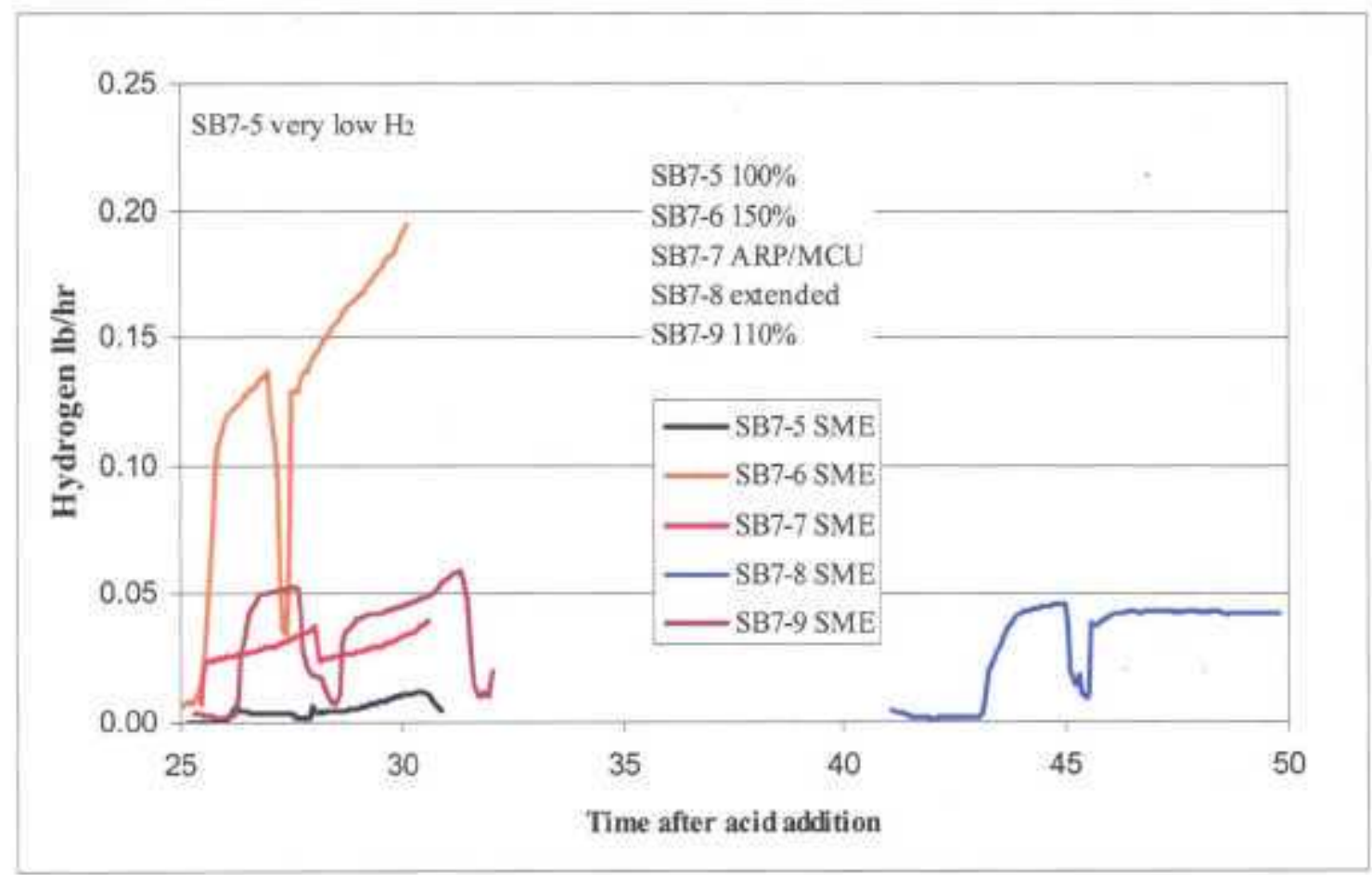

Figure 19 Flowsheet SME Hydrogen Generation 


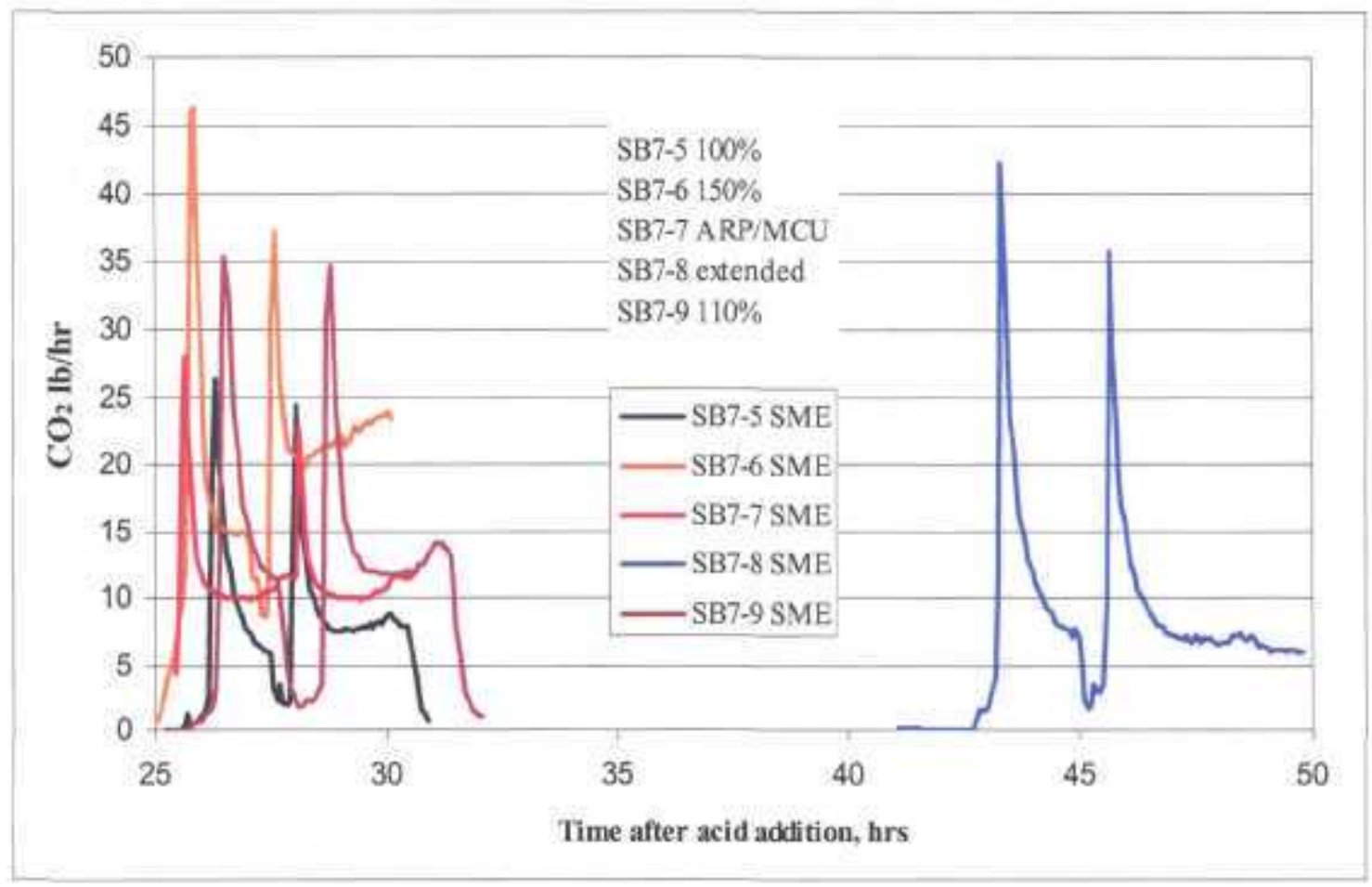

Figure 20 Flowsheet SME $\mathrm{CO}_{2}$ Generation

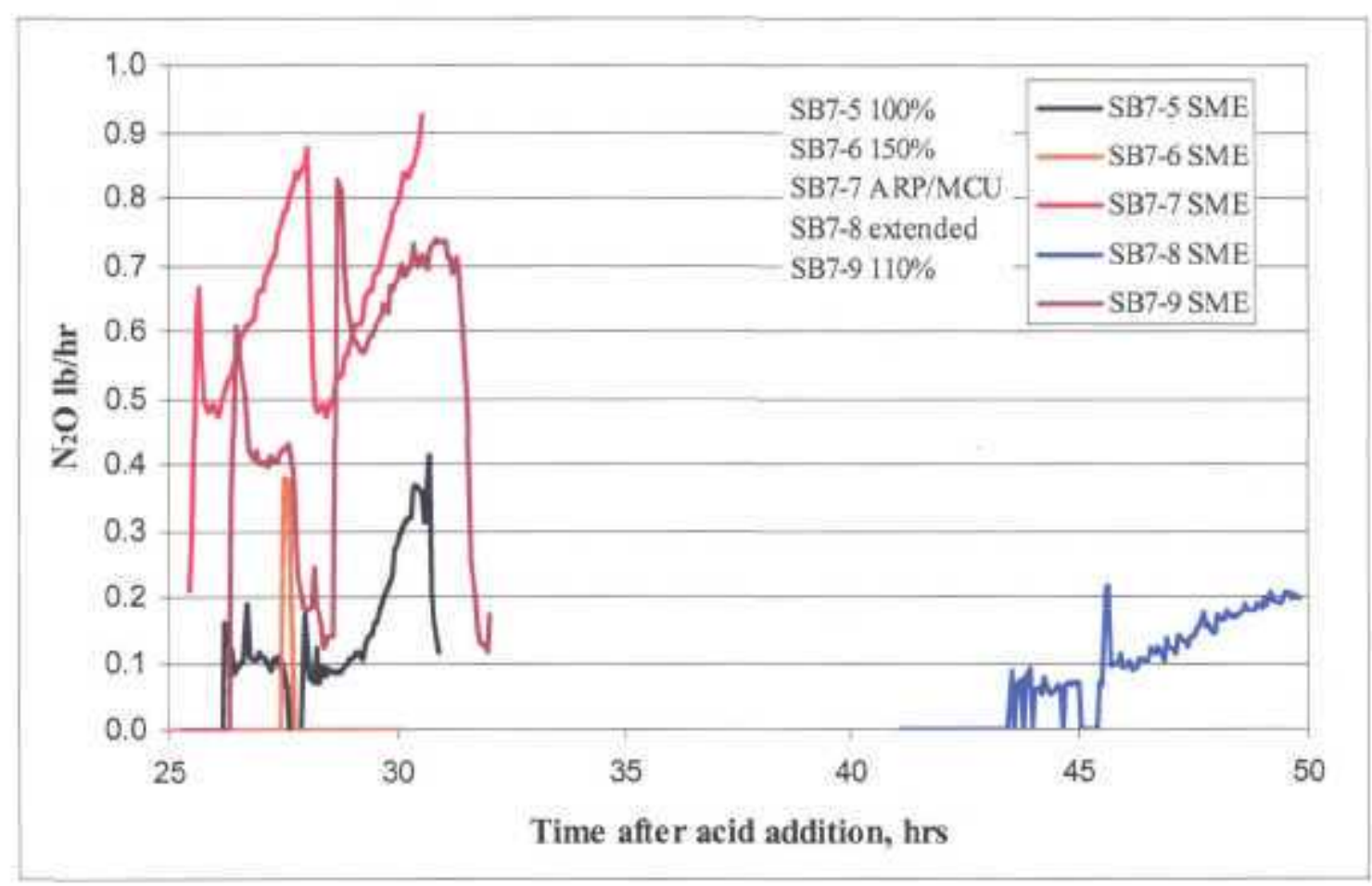

Figure 21 Flowsheet $\mathrm{SME} \mathrm{N}_{2} \mathrm{O}$ Generation 


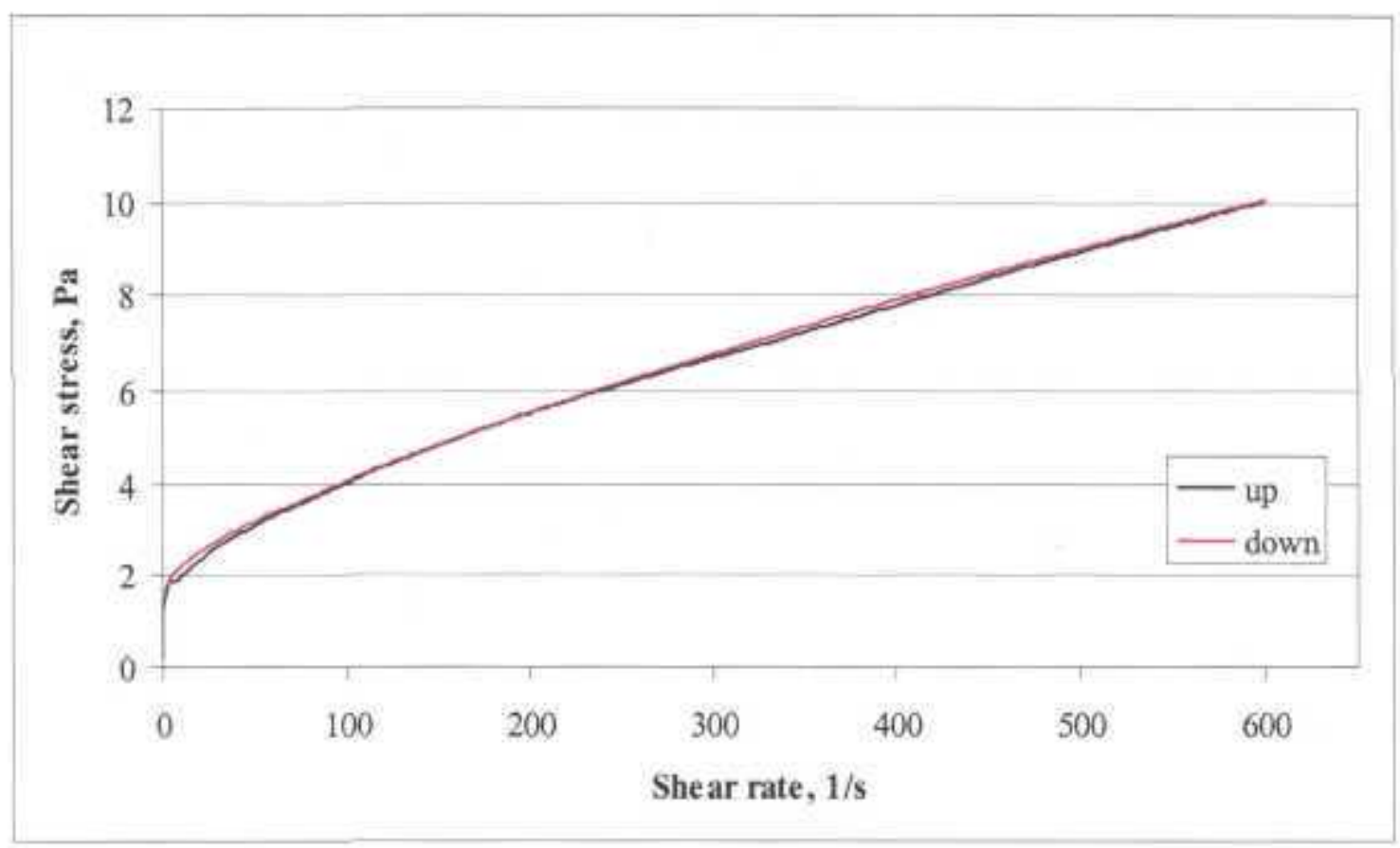

Figure 22 SB7-1 SRAT Rheology Flow Curve

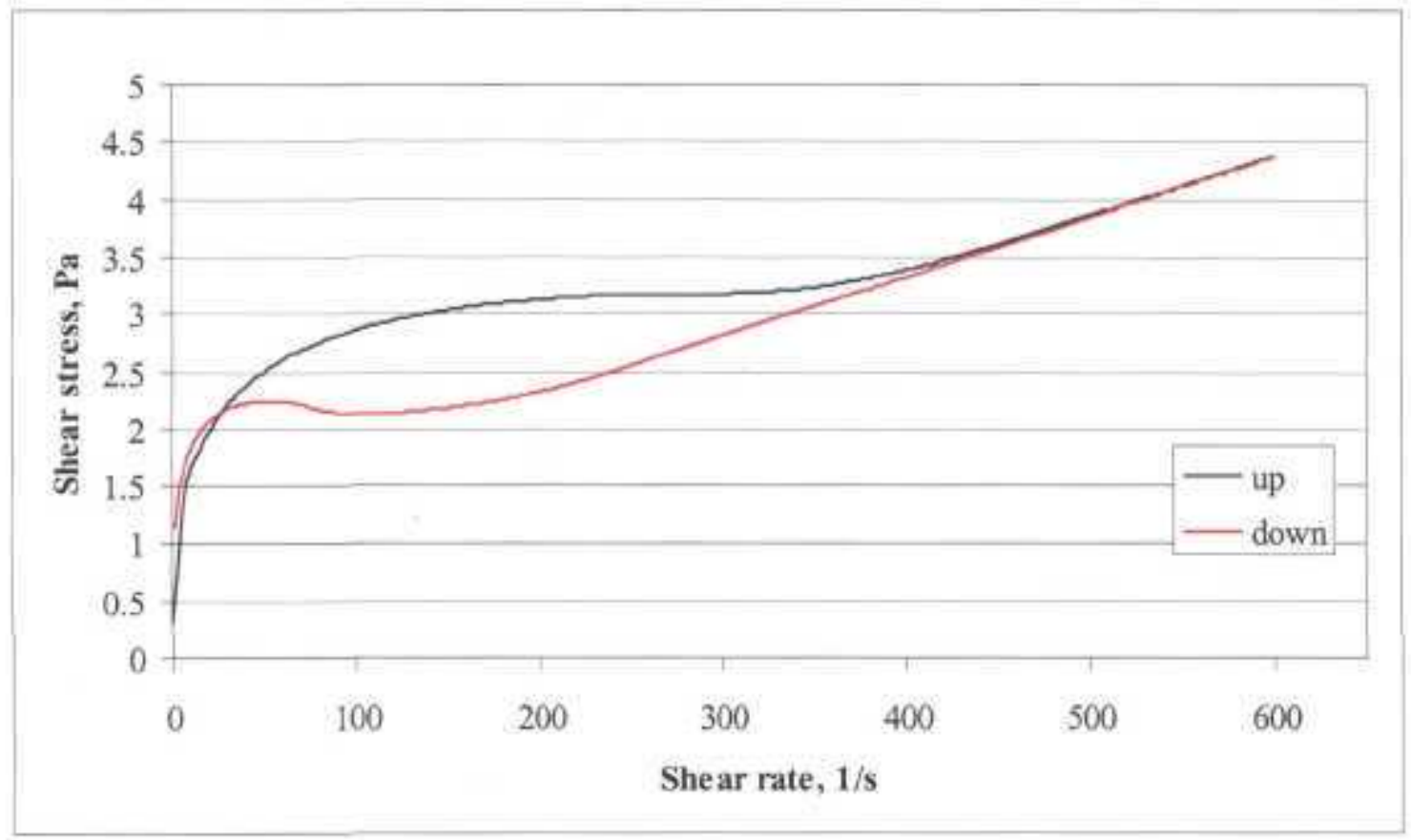

Figure 23 SB7-2 SRAT Rheology Flow Curve 

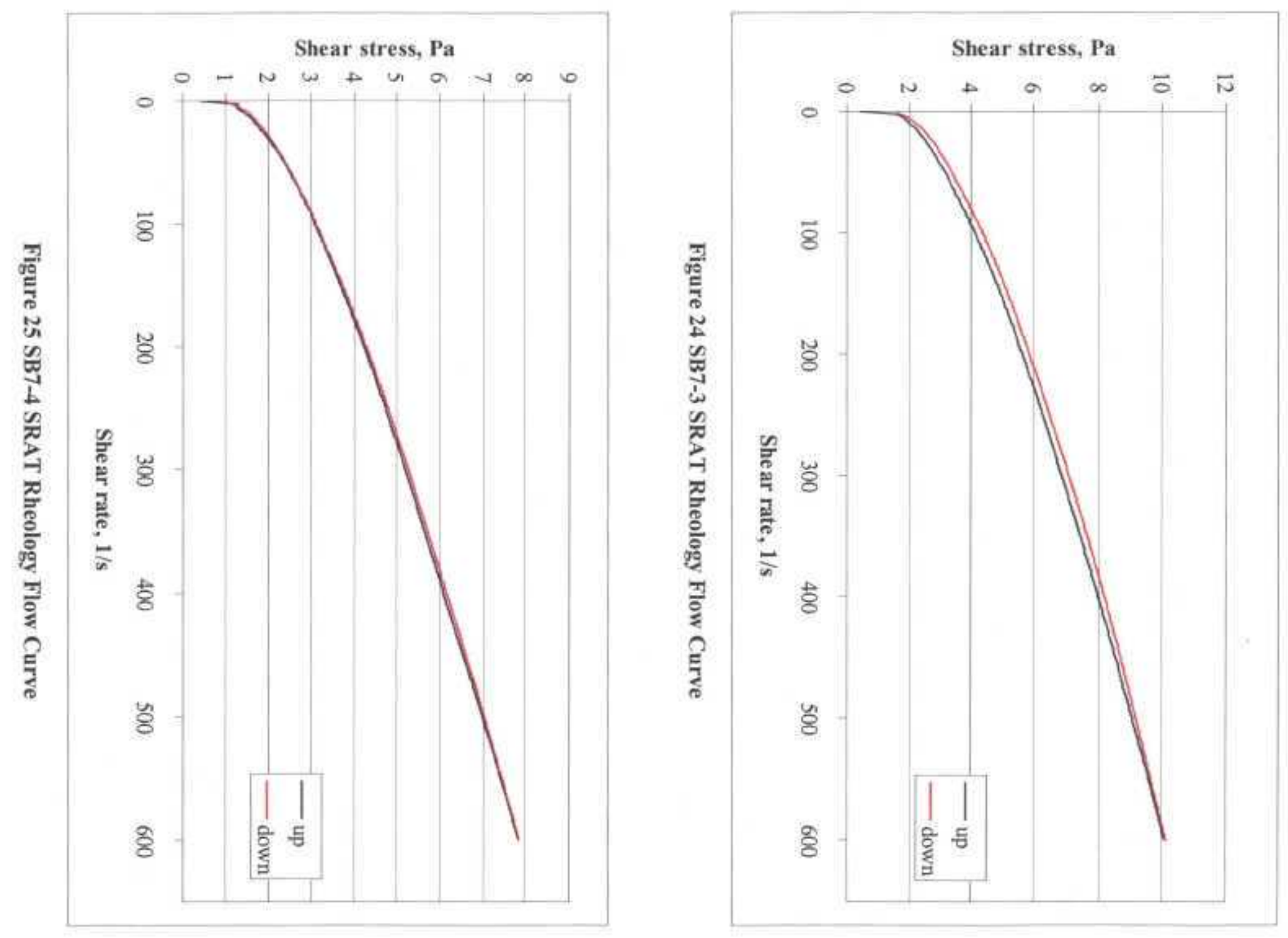

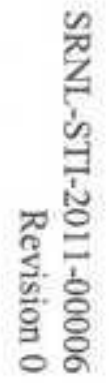




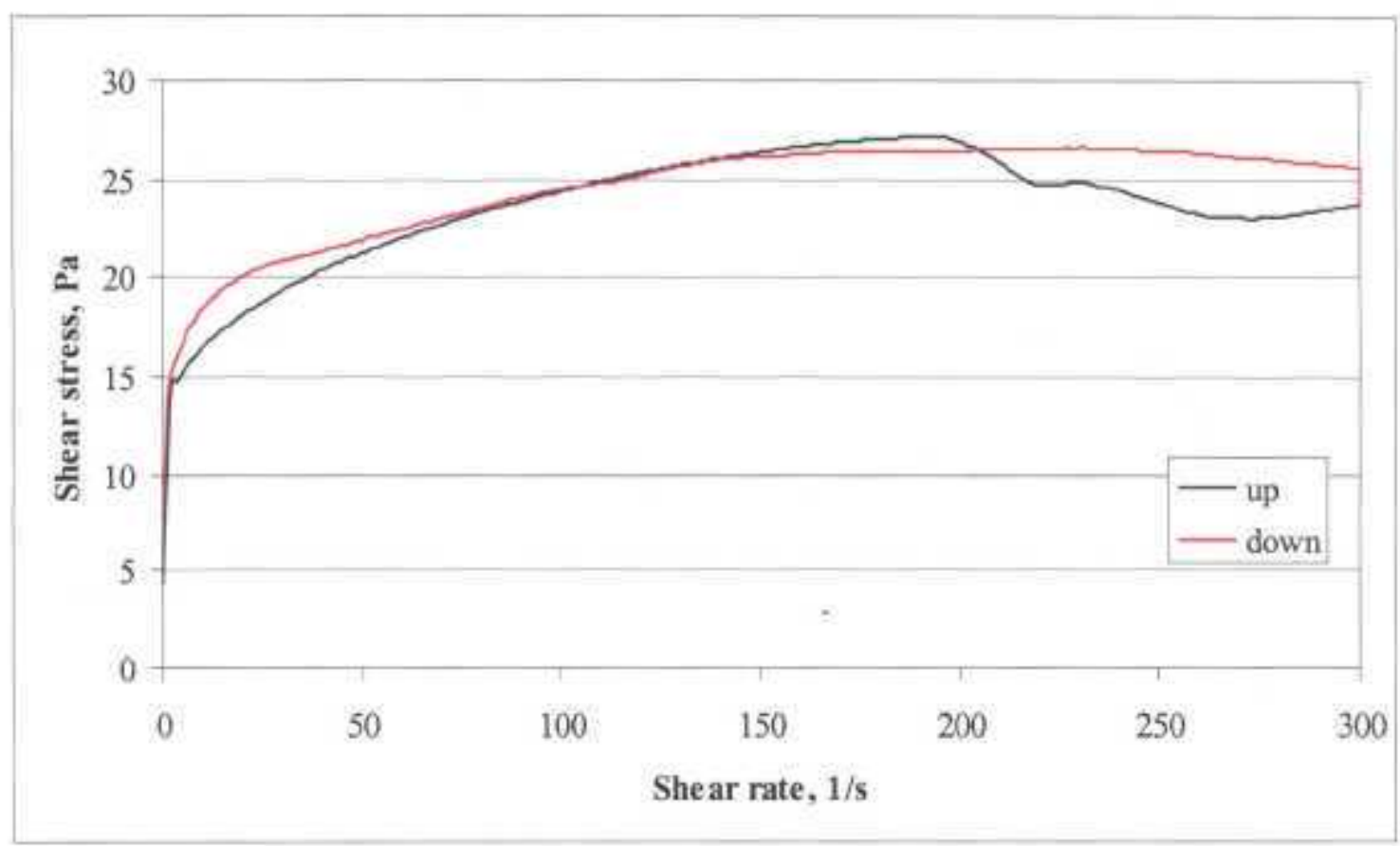

Figure 26 SB7-1 SME Rheology Flow Curve

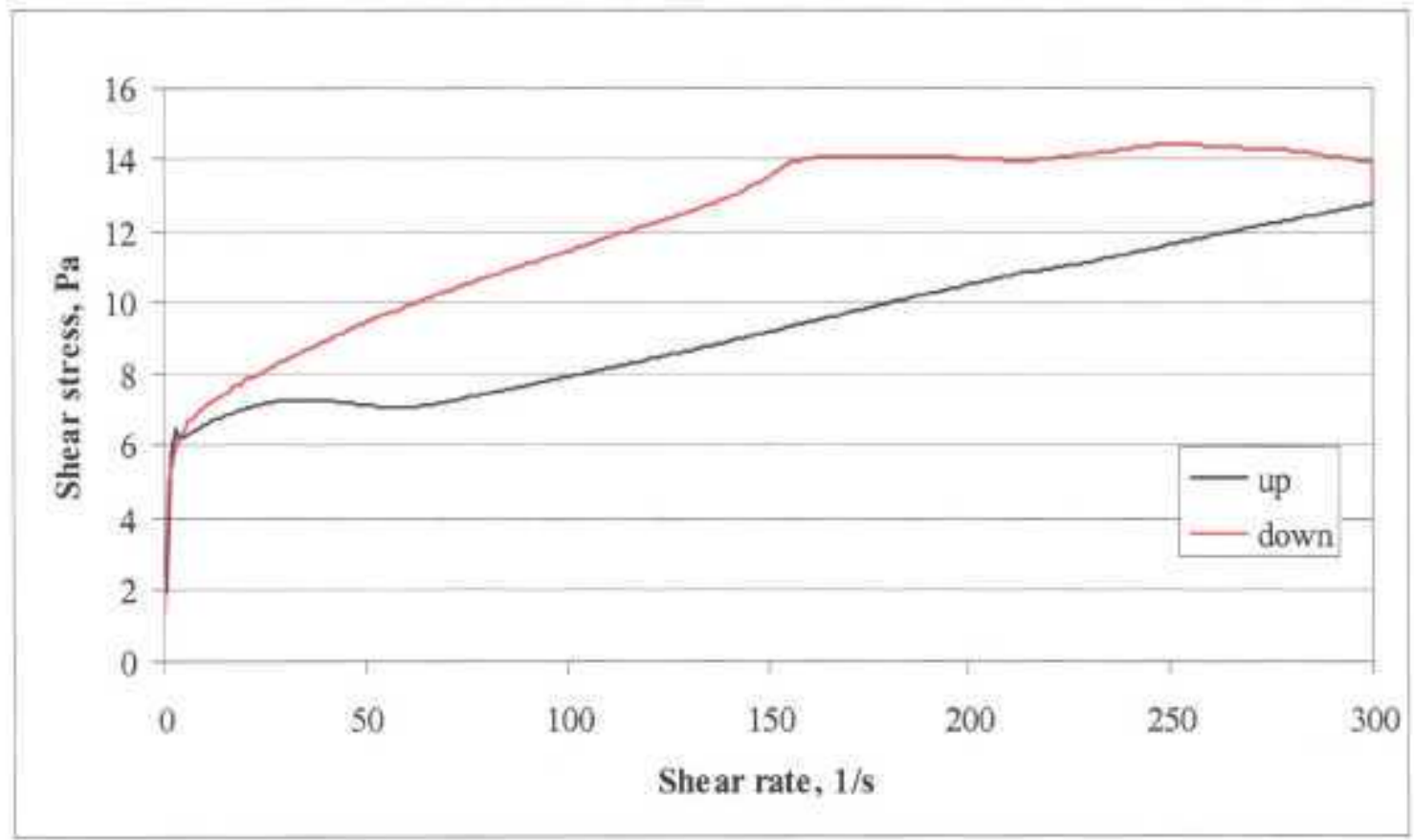

Figure 27 SB7-2 SME Rheology Flow Curve 


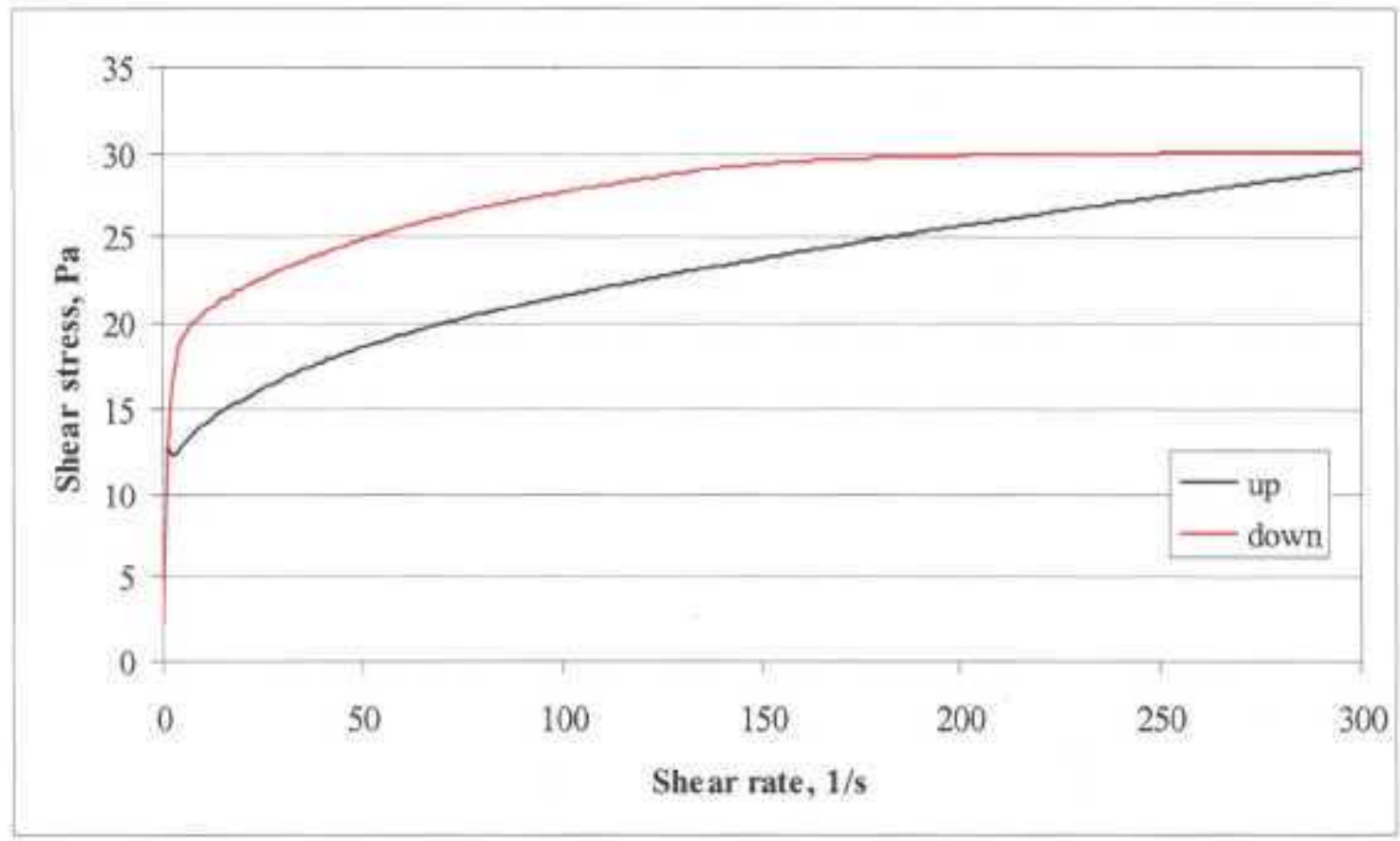

Figure 28 SB7-3 SME Rheology Flow Curve

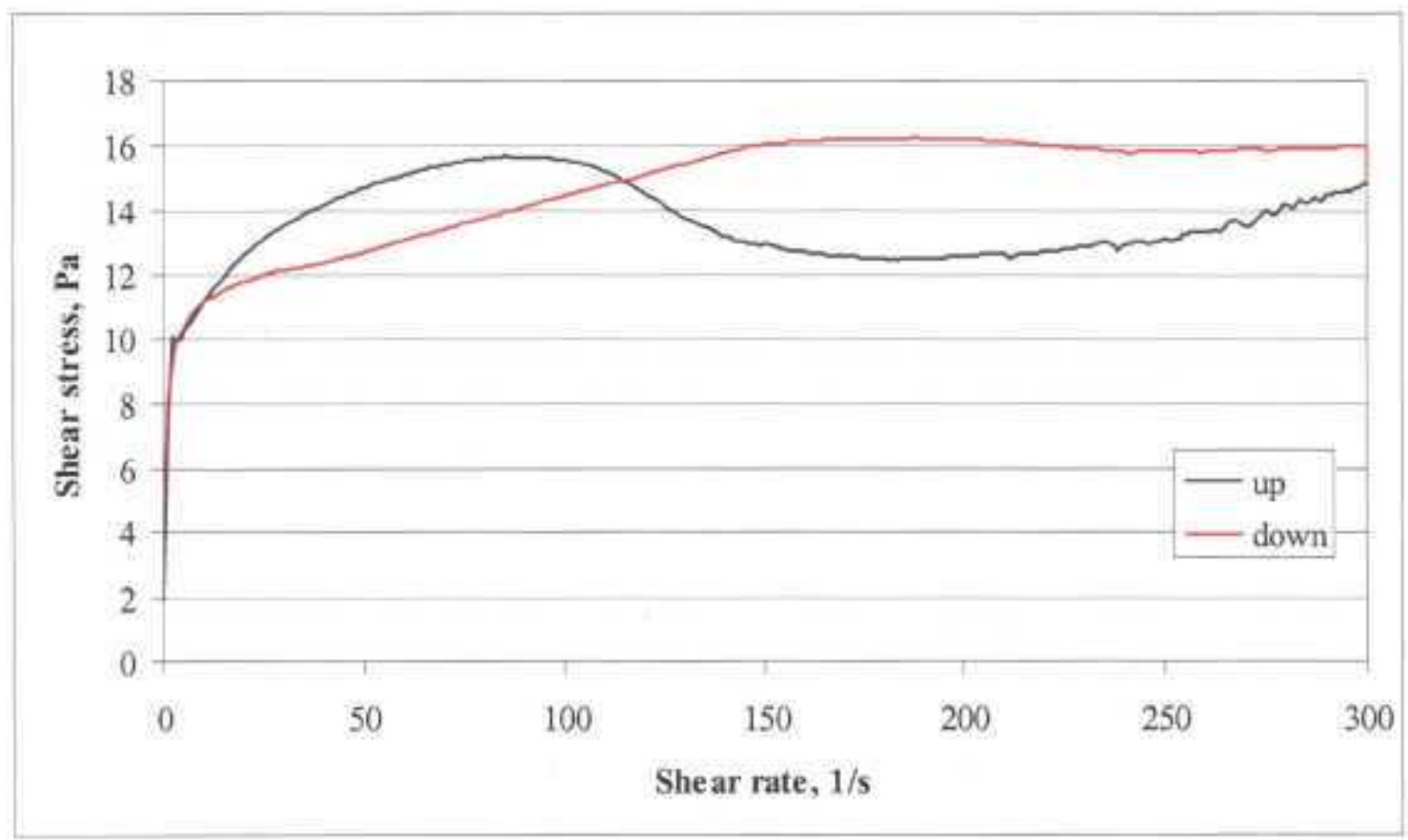

Figure 29 SB7-4 SME Rheology Flow Curve 
SRNL-STI-2011-00006

Revision 0

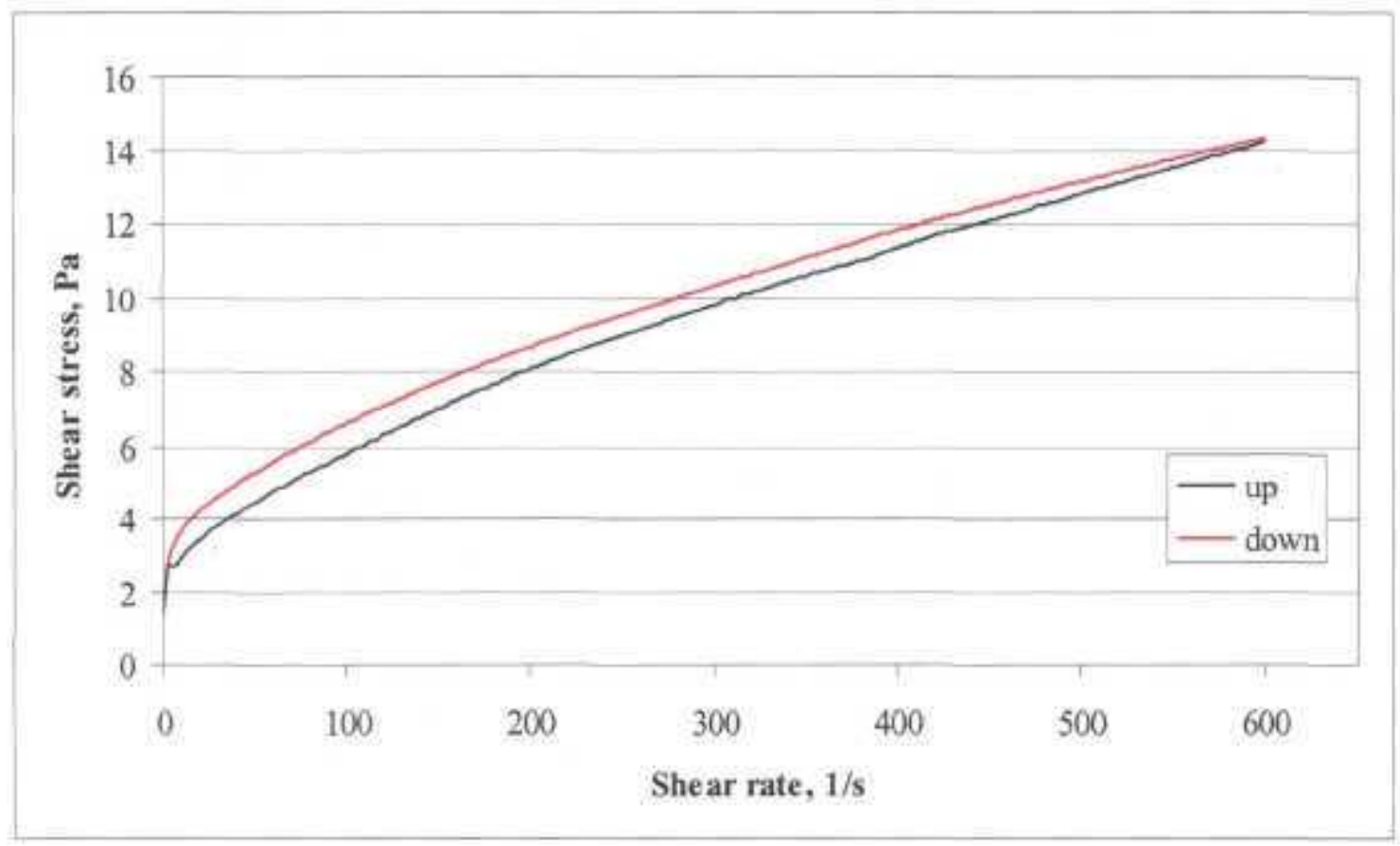

Figure 30 SB7-5 SRAT Rheology Flow Curve

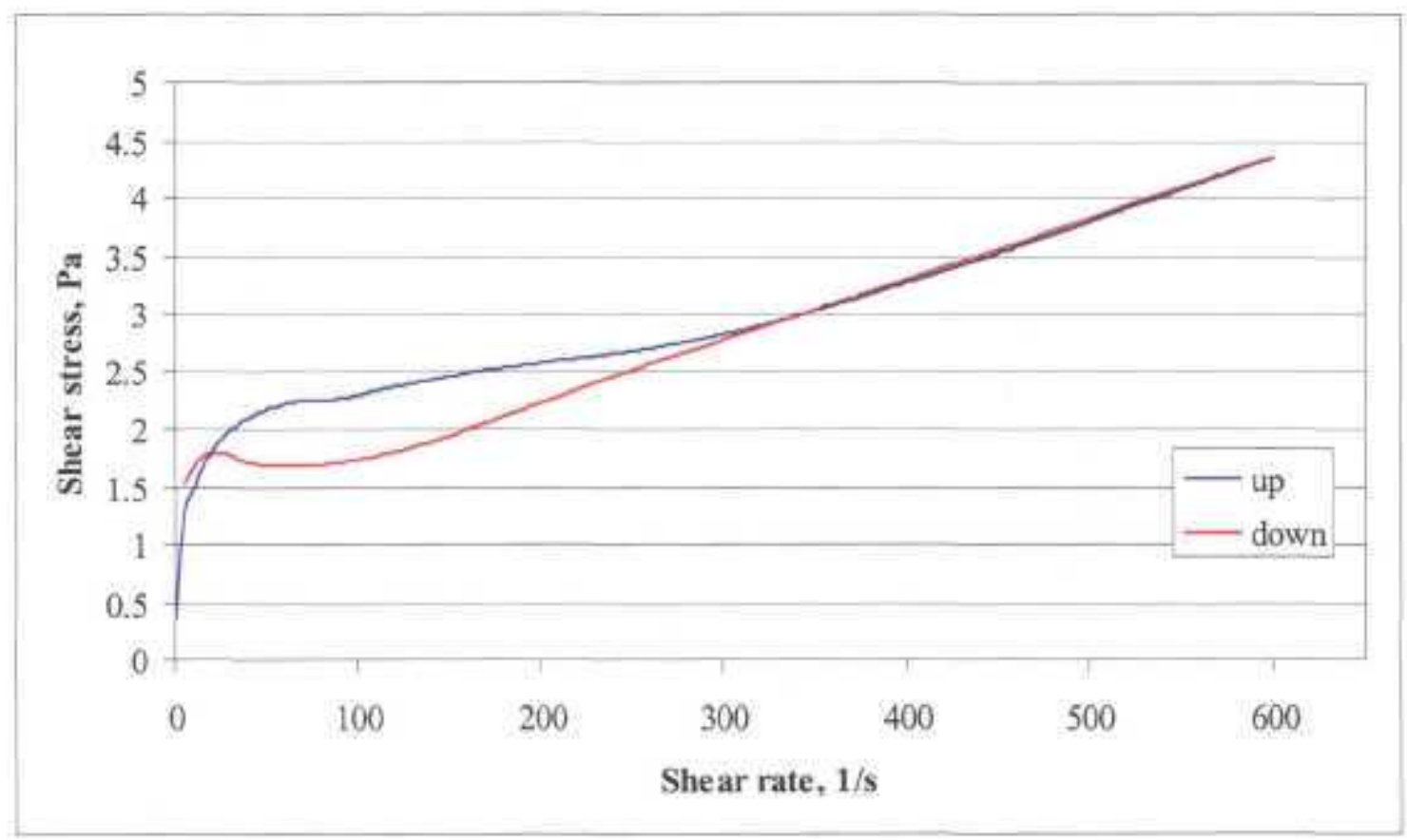

Figure 31 SB7-6 SRAT Rheology Flow Curve 


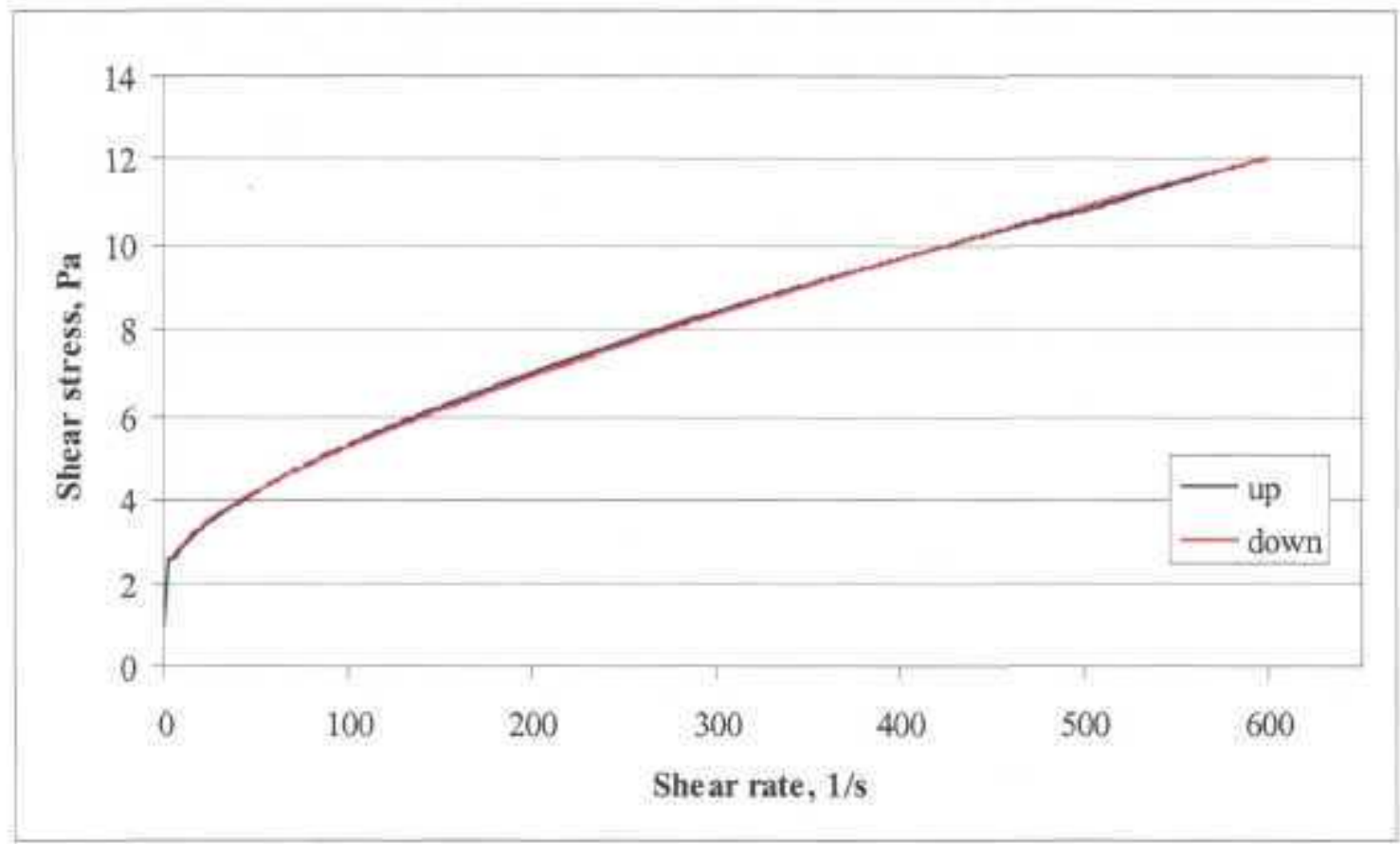

Figure 32 SB7-7 SRAT Rheology Flow Curve

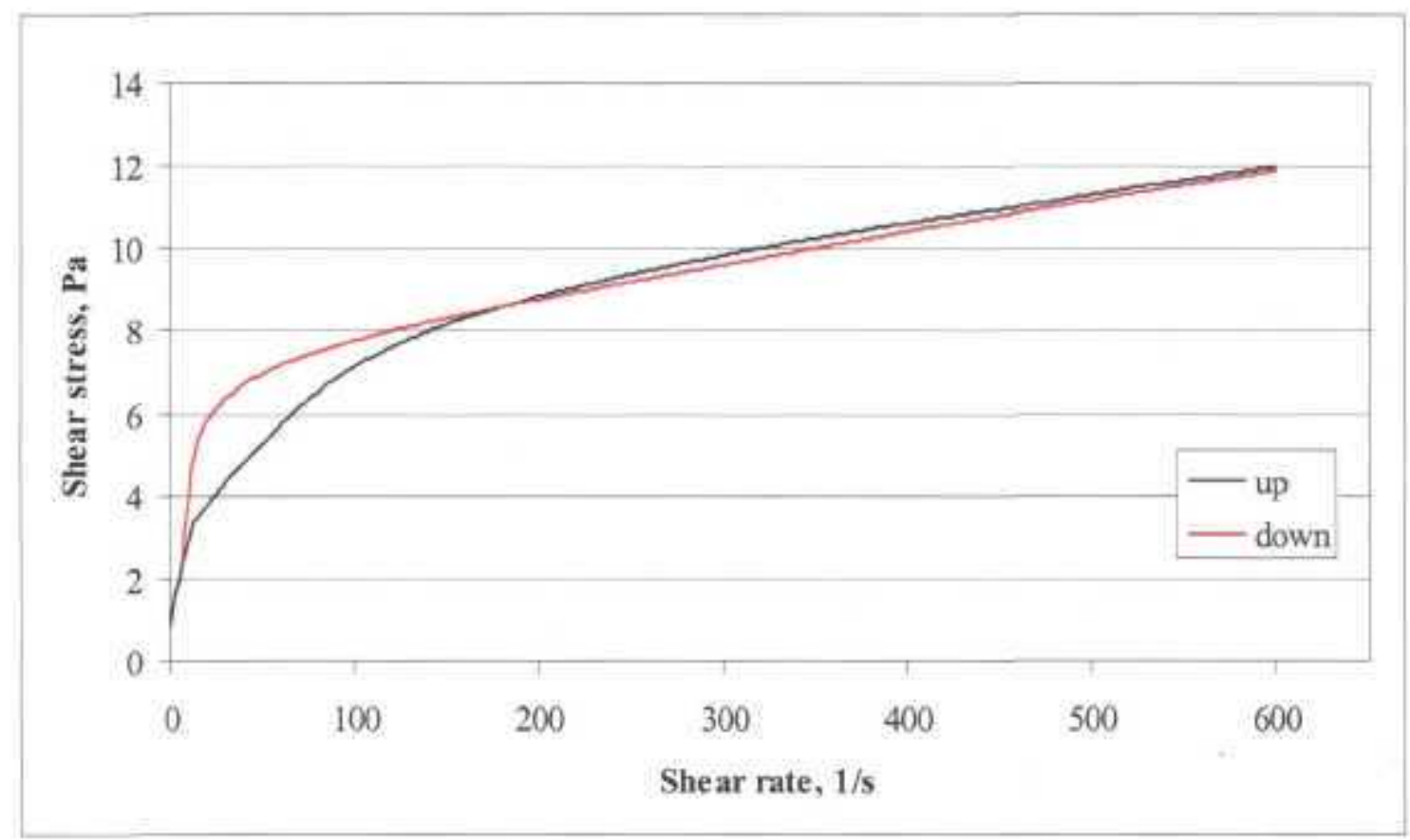

Figure 33 SB7-8 SRAT Rheology Flow Curve 

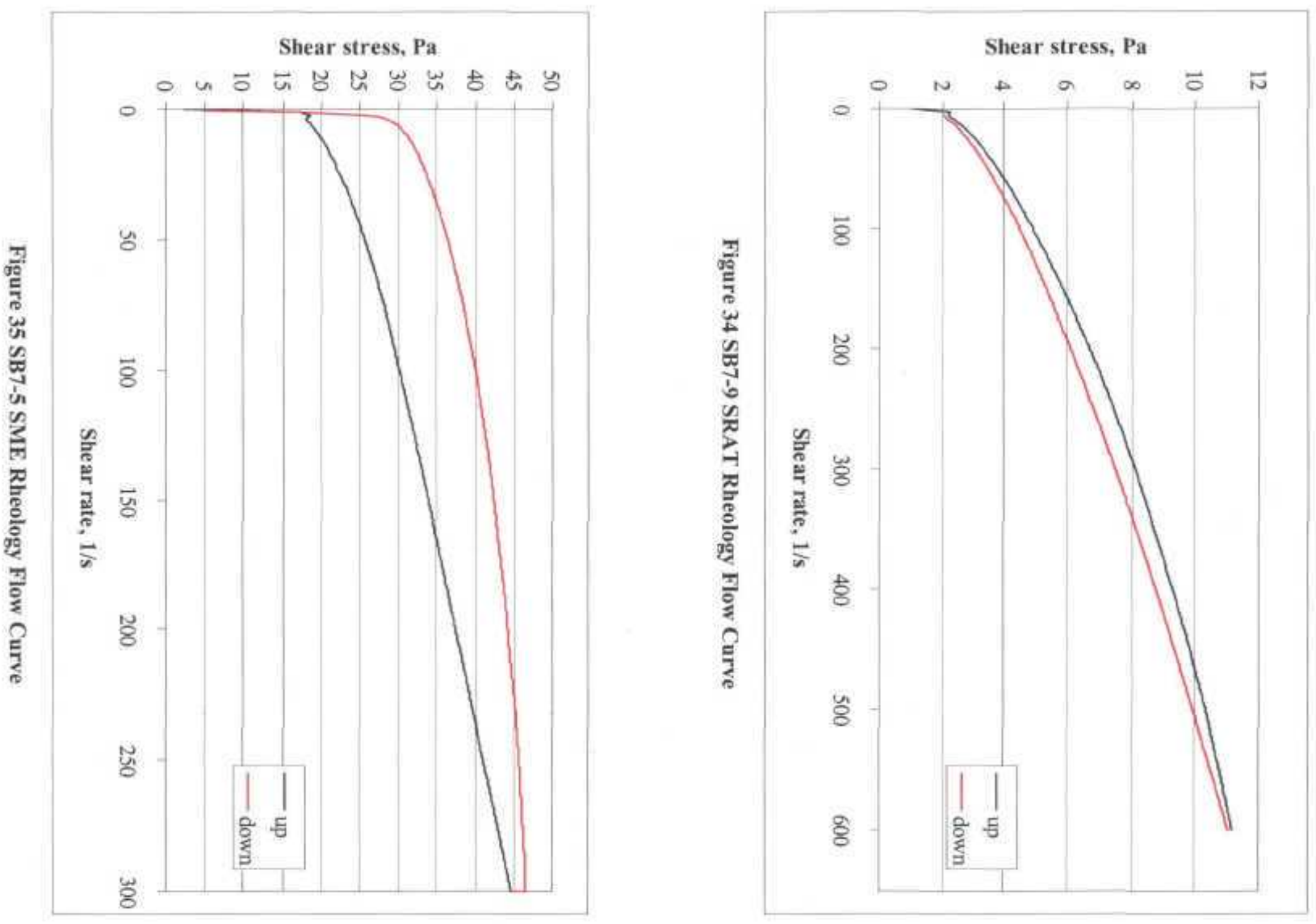

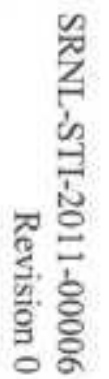



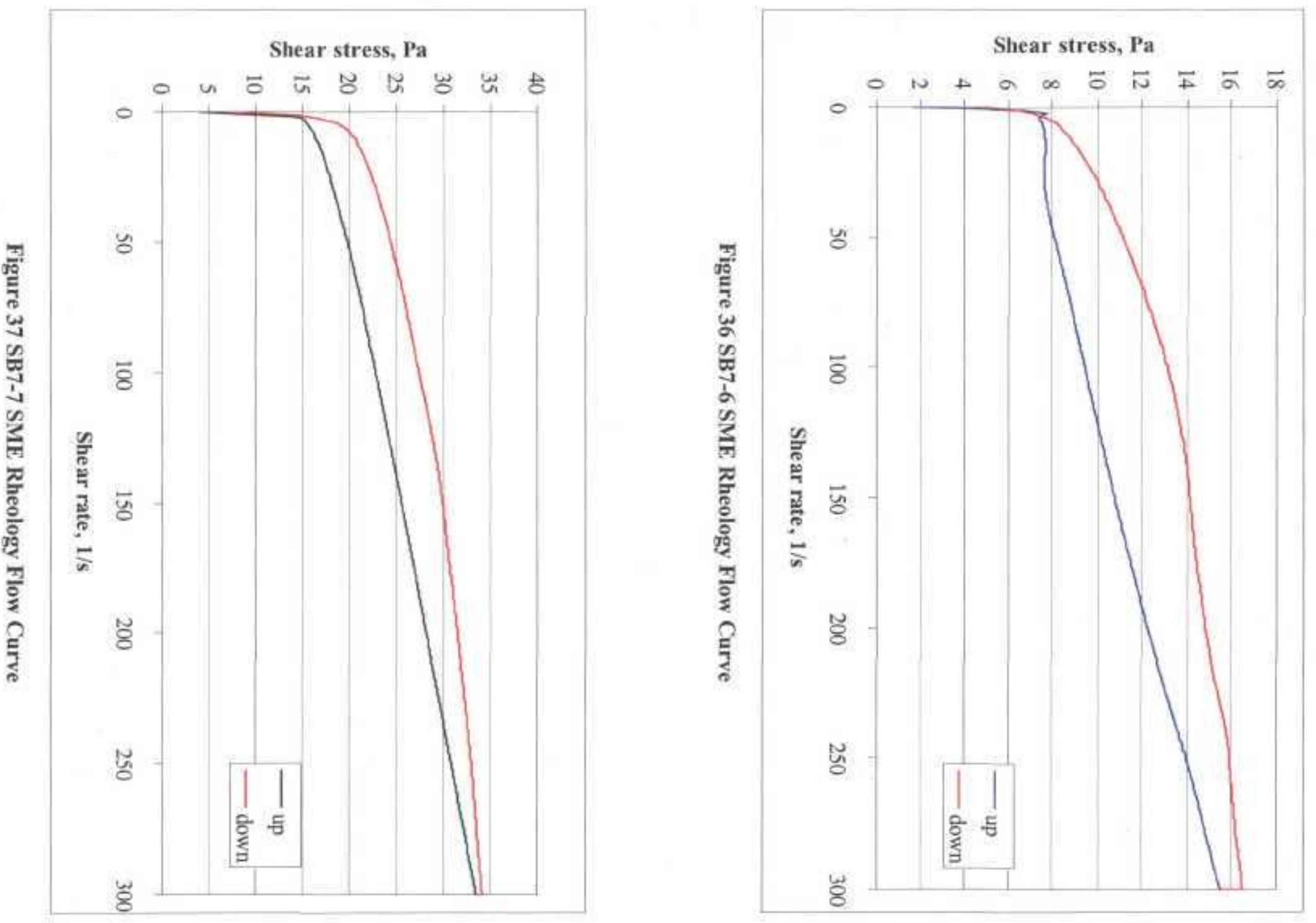

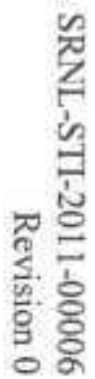



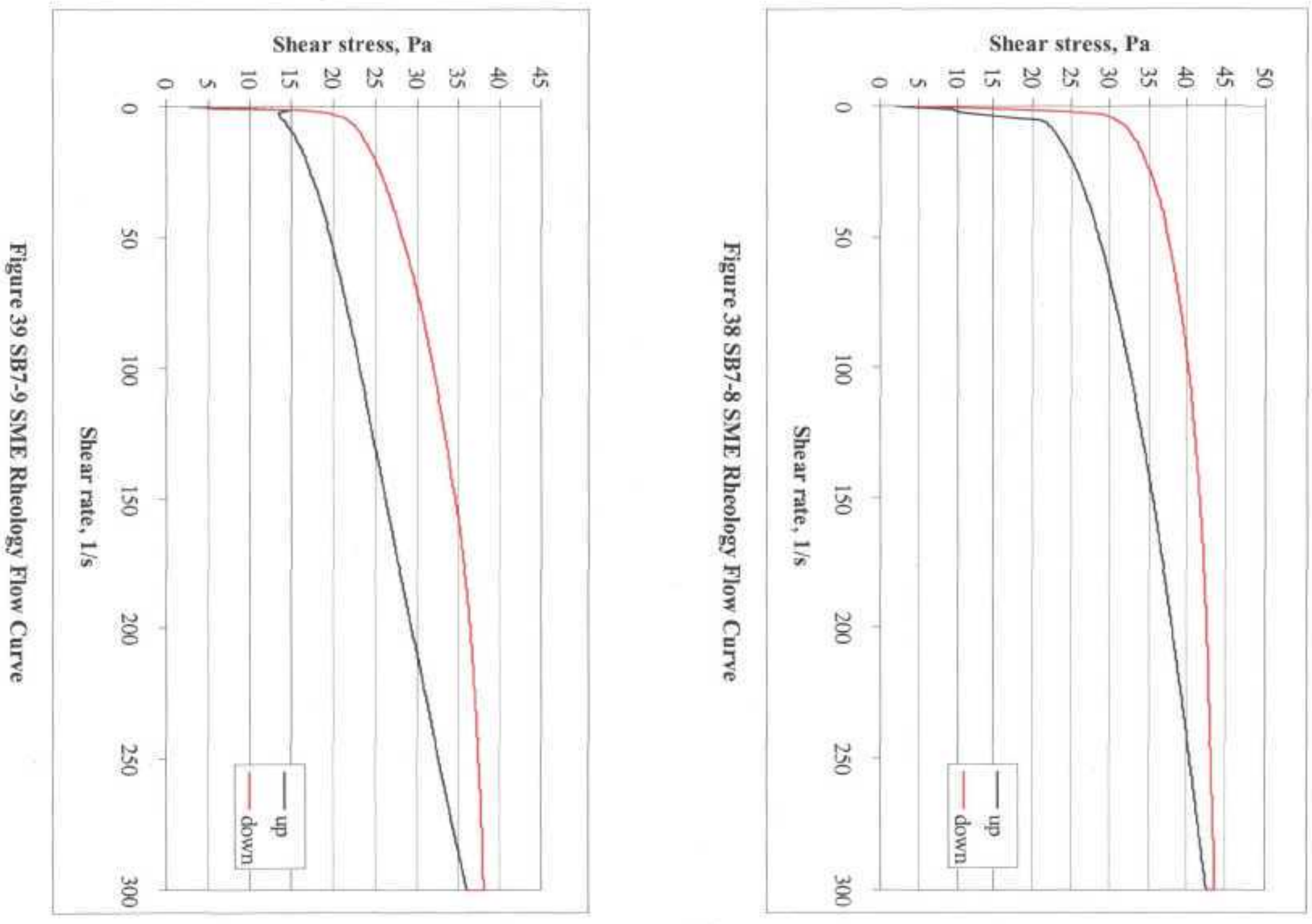

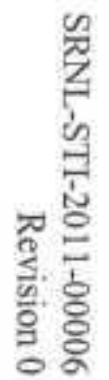




\section{Distribution:}
A. B. Barnes, 999-W
D. A. Crowley, 773-43A
S. D. Fink, 773-A
B. J. Giddings, $786-5 \mathrm{~A}$
C. C. Herman, 999-W
S. L. Marra, 773-A
P. R. Jackson, 773-A
A. S. Choi, 773-42A
J. M. Gillam, 766-H
B. A. Hamm, 766-H
J. F. Iaukea, 704-30S
D. C. Koopman, 999-W
D. P. Lambert, 999-W
J. D. Newell, 999-W
J. E. Occhipinti, 704-S
J. M. Pareizs, 773-A
D. K. Peeler, 999-W
J. W. Ray, 704-S
S. H. Reboul, 773-A
H. B. Shah, 766-H
D. C. Sherburne, 704-S
A.V. Staub, 704-27S
M. E. Stone, 999-W
J. R. Zamecnik, 999-W
J. M. Bricker, 704-27S
T. L. Fellinger, 704-26S
E. W. Holtzscheiter, 704-15S
M. T. Keefer, 766-H 